\title{
Shallow Ground-Water Quality Beneath Cropland in the Red River of the North Basin, Minnesota and North Dakota, 1993-95
}

\section{U.S. Geological Survey}

Water-Resources Investigations Report 97-4001

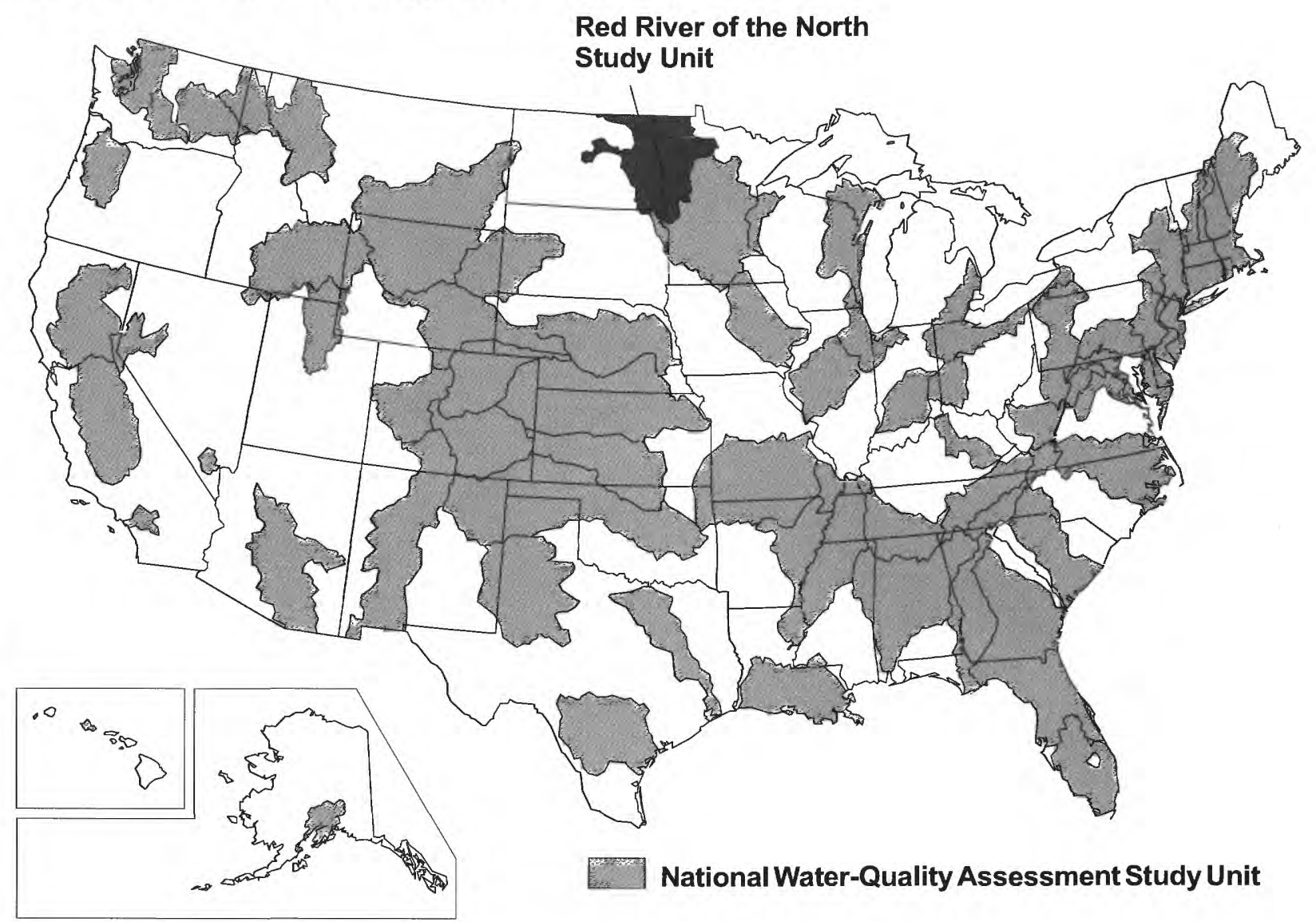

Contribution from the National Water-Quality Assessment Program

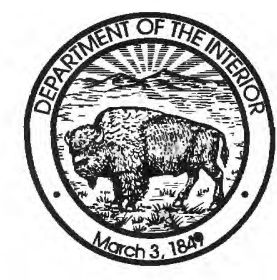




\section{Shallow Ground-Water Quality Beneath Cropland in the Red River of the North Basin, Minnesota and North Dakota, 1993-95}

By Timothy K. Cowdery

U.S. Geological Survey

Water-Resources Investigations Report 97-4001

Contribution from the National Water-Quality Assessment Program

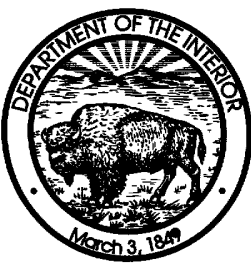




\section{U.S. DEPARTMENT OF THE INTERIOR}

BRUCE BABBITT, Secretary

U.S. GEOLOGICAL SURVEY

Gordon P. Eaton, Director

For additional information write to:

Copies of this report can be purchased from:

District Chief

U.S. Geological Survey

2280 Woodale Drive

Mounds View, MN 55112
U.S. Geological Survey

Branch of Information Services

Box 25286

Denver Federal Center

Denver, CO 80225-0286

Information regarding the National Water-Quality Assessment (NAWQA) Program is available on the Internet via the World Wide Web. You may connect to the Red River of the North NAWQA Home Page at:

http://wwwmn.cr.usgs.gov/redn/index.html 


\section{Foreword}

The mission of the U.S. Geological Survey (USGS) is to assess the quantity and quality of the earth resources of the Nation and to provide information that will assist resource managers and policymakers at Federal, State, and local levels in making sound decisions. Assessment of water-quality conditions and trends is an important part of this overall mission.

One of the greatest challenges faced by waterresources scientists is acquiring reliable information that will guide the use and protection of the Nation's water resources. That challenge is being addressed by Federal, State, interstate, and local water-resource agencies and by many academic institutions. These organizations are collecting water-quality data for a host of purposes that include: compliance with permits and water-supply standards; development of remediation plans for specific contamination problems; operational decisions on industrial, wastewater, or water-supply facilities; and research on factors that affect water quality. An additional need for water-quality information is to provide a basis on which regional- and national-level policy decisions can be based. Wise decisions must be based on sound information. As a society we need to know whether certain types of waterquality problems are isolated or ubiquitous, whether there are significant differences in conditions among regions, whether the conditions are changing over time, and why these conditions change from place to place and over time. The information can be used to help determine the efficacy of existing water-quality policies and to help analysts determine the need for and likely consequences of new policies.

To address these needs, the U.S. Congress appropriated funds in 1986 for the USGS to begin a pilot program in seven project areas to develop and refine the National Water-Quality Assessment (NAWQA) Program. In 1991, the USGS began full implementation of the program. The NAWQA Program builds upon an existing base of water-quality studies of the USGS, as well as those of other Federal, State, and local agencies. The objectives of the NAWQA Program are to:

- Describe current water-quality conditions for a large part of the Nation's freshwater streams, rivers, and aquifers.

- Describe how water quality is changing over time.

- Improve understanding of the primary natural and human factors that affect water-quality conditions.
This information will help support the development and evaluation of management, regulatory, and monitoring decisions by other Federal, State, and local agencies to protect, use, and enhance water resources.

The goals of the NAWQA Program are being achieved through ongoing and proposed investigations of 60 of the Nation's most important river basins and aquifer systems, which are referred to as study units. There study units are distributed throughout the Nation and cover a diversity of hydrogeologic settings. More than two-thirds of the Nation's freshwater use occurs within the 60 study units and more than two-thirds of the people served by public water-supply systems live within their boundaries.

National synthesis of data analysis, based on aggregation of comparable information obtained from the study units, is a major component of the program. This effort focuses on selected water-quality topics using nationally consistent information. Comparative studies will explain differences and similarities in observed water-quality conditions among study areas and will identify changes and trends and their causes. The first topics addressed by the national synthesis are pesticides, nutrients, volatile organic compounds, and aquatic biology. Discussions on these and other waterquality topics will be published in periodic summaries of the quality of the Nation's ground and surface water as the information becomes available.

This report is an element of the comprehensive body of information developed as part of the NAWQA Program. The program depends heavily on the advice, cooperation, and information from many Federal, State, interstate, Tribal, and local agencies and the public. The assistance and suggestions of all are greatly appreciated.

\author{
Robert M. Hirsch \\ Chief Hydrologist
}




\section{Contents}

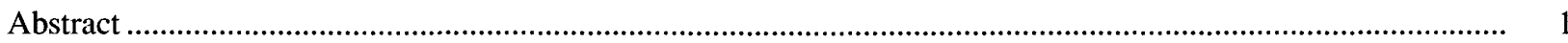

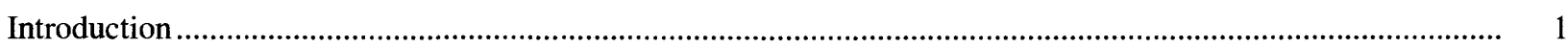

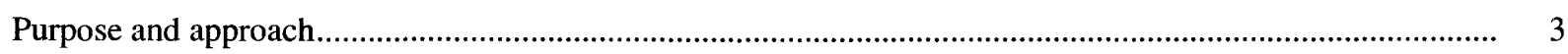

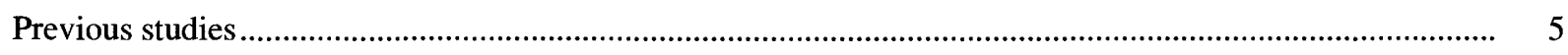

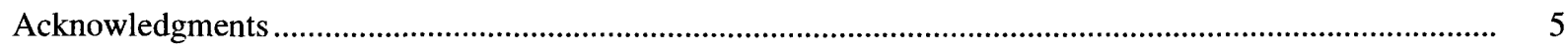

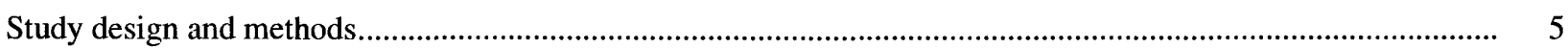

Site selection, well construction, and sampling-network characteristics ........................................................ 6

Sample collection, analysis, and quality control............................................................................ 7

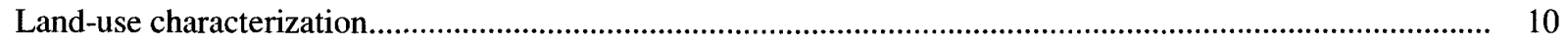

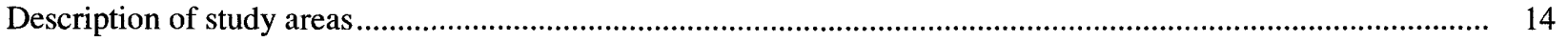

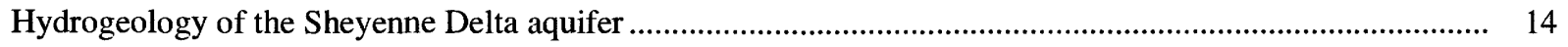

Hydrogeology of the Otter Tail outwash aquifer ......................................................................................... 15

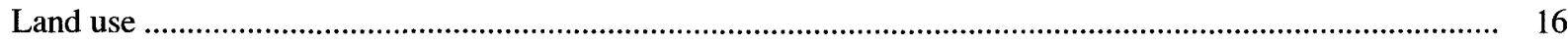

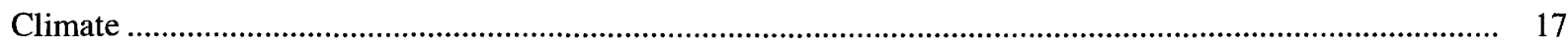

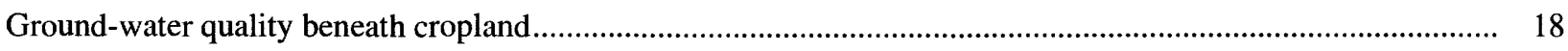

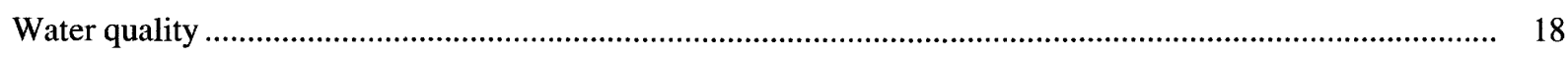

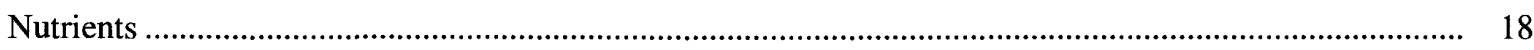

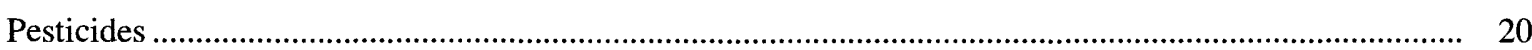

Volatile organic compounds and radioactive elements ................................................................ 21

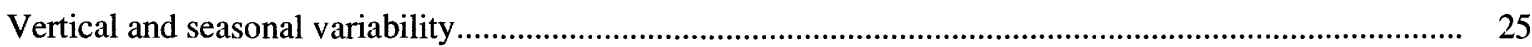

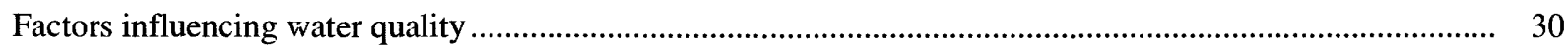

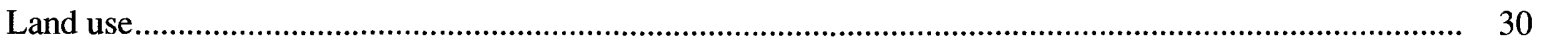

Hydrogeology .................................................................................................................................... 32

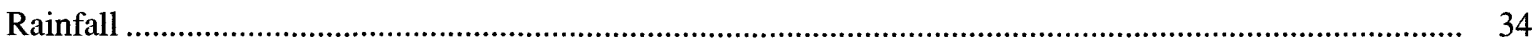

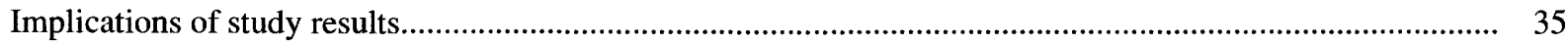

Drinking water implications .................................................................................................................... $\quad 36$

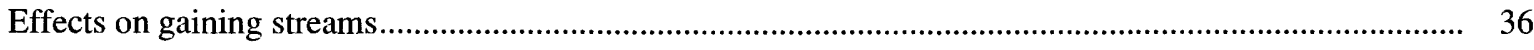

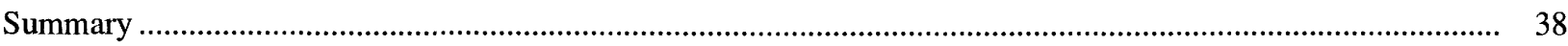

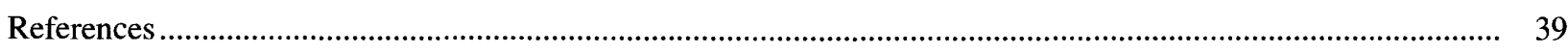

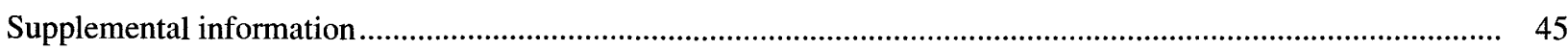

\section{Illustrations}

Figure 1. Study area locations, surficial aquifers, and physiographic areas................................................... 2

2. Land-use study areas and sampling networks.....................................................................................

3. Well characteristics of land-use sampling networks at the time of sampling .................................... 7

4. Ground-water quality-control data for land-use samples.............................................................. 9 


\section{Illustrations-continued}

5. Conceptual ground-water recharge and flow to a well screened at the water table.

6. Major-ion chemistry of shallow ground water from land-use study areas

7. Nitrate and ammonia concentrations in shallow ground water from land-use study areas

8. Distribution of nitrate and pesticides in shallow ground water from land-use study areas.

9. Uranium, radium, and radon concentrations in shallow ground water from the Sheyenne Delta study area.

10. Vertical nitrate distribution in ground water along the flow-path transect in the OtterTail outwash study area.

11. Recharge dates of ground water, based on chloroflourocarbon analyses, along the flow-path transect in the Otter Tail outwash study area.

12. Seasonal nitrate variability in shallow ground water from land-use study areas

13. Pesticide concentrations in shallow ground water from land-use study areas

14. Water levels during sampling of ground water from land-use study areas

15. Precipitation in the land-use study areas, based on 1966-95 data. 34

16. Examplar hydrographs from land-use study areas 35

\section{Tables}

Table 1. Well statistics of land-use sampling networks

2. Analytical method references

3. Ground-water modeling factors for flow in land-use study areas

4. Land-use comparison of land-use study areas

5. Average crop and irrigation area for land-use study areas during 1992-93

6. Estimated average nutrient use in land-use study areas

7. Estimated average herbicide use in land-use study areas

8. Nutrient concentrations in shallow ground water from land-use study areas ................................... 21

9. Pesticide concentrations in shallow ground water from land-use study areas ..................................... 23

10. Pesticide concentrations in shallow ground water from land-use study areas

11. Volatile organic compounds in shallow ground water from the Sheyenne Delta study area

12. Water-quality factors affecting agricultural-chemical concentrations in shallow ground water from sandy, surficial aquifers beneath cropland

13. Shallow ground-water-quality summary from land-use study areas. 39

14. Well characteristics of sampling networks. 46

15. Quality-control synopsis 


\section{Conversion Factors, Vertical Datum and Abbreviations}

$\begin{array}{lll}\text { Multiply Inch-Pound Unit } & \text { By } & \text { To Obtain Metric Unit } \\ \text { foot (ft) } & 0.3048 & \text { meter } \\ \text { foot/day (ft/d) } & 3.528 \times 10^{-4} & \text { centimeter per second } \\ \text { inch (in.) } & 2.54 & \text { centimeter } \\ \text { gallon per minute }(\mathrm{gal} / \mathrm{min}) & .06308 & \text { liter per second } \\ \text { mile (mi) } & 1.609 & \text { kilometer } \\ \text { pound per acre } & 1.121 & \text { kilogram per hectare } \\ \text { square mile }\left(\mathrm{mi}^{2}\right) & 2.590 & \text { square kilometer }\end{array}$

Temperature in degrees Fahrenheit $\left({ }^{\circ} \mathrm{F}\right)$ is converted to degrees Celsius $\left({ }^{\circ} \mathrm{C}\right)$ by: ${ }^{\circ} \mathrm{C}=\left({ }^{\circ} \mathrm{F}-32\right) / 1.8$

Sea level: In this report "sea level" refers to the National Geodetic Vertical Datum of 1929 (NGVD of 1929)—a geodetic datum derived from a general adjustment of the first-order level nets of both the United States and Canada, formerly called Sea Level Datum of 1929.

$\mathrm{mg} / \mathrm{L} \quad$ milligram per liter

$\mu \mathrm{g} / \mathrm{L} \quad$ microgram per liter

$\mathrm{pCi} / \mathrm{L} \quad$ picocurie per liter

MCL maximum contaminant level

DOC dissolved organic carbon

DO dissolved oxygen

BP before present

Use of trade names in this report is for identification purposes only and does not constitute endorsement by the U.S. Geological Survey. 


\title{
Shallow Ground-Water Quality Beneath Cropland in the Red River of the North Basin, Minnesota and North Dakota, 1993-95
}

\author{
By Timothy K. Cowdery
}

\begin{abstract}
During 1993-95, the agriculture on two sandy, surficial aquifers in the Red River of the North Basin affected the quality of shallow ground water in each aquifer differently. The Sheyenne Delta aquifer, in the western part of the basin, had land-use, hydrogeological, and rainfall characteristics that allowed few agricultural chemicals to reach or remain in the shallow ground water. The Otter Tail outwash aquifer, in the eastern part of the basin, had characteristics that caused significant amounts of nutrients and pesticides to reach and remain in the shallow ground water. Shallow ground water from both aquifers is dominated by calcium, magnesium, and bicarbonate ions. During the respective sampling periods, water from the Sheyenne Delta aquifer was mostly anoxic and water from the Otter Tail outwash aquifer had a median dissolved oxygen concentration of $3.6 \mathrm{mg} / \mathrm{L}$ (milligrams per liter). The median nitrate concentration was $0.03 \mathrm{mg} / \mathrm{L}$ as nitrogen $(\mathrm{mg} / \mathrm{L}-\mathrm{N})$ in shallow ground water from the Sheyenne Delta aquifer and $6.1 \mathrm{mg} / \mathrm{L}-\mathrm{N}$ in that from the Otter Tail outwash aquifer. Of 18 herbicides and 4 insecticides commonly used in the aquifer areas and for which analyses were done, 5 herbicides and 1 herbicide metabolite were detected in the shallow ground water from the Sheyenne Delta aquifer and 8 herbicides and 2 metabolites were detected in that from the Otter Tail outwash aquifer. The total herbicide concentration median was less than the detection limit in shallow ground water from the Sheyenne Delta aquifer and $0.023 \mu \mathrm{g} / \mathrm{L}$ (micorgrams per liter) in that from the Otter Tail outwash aquifer. Triazine herbicides were the most commonly detected herbicides and were detected at the highest concentrations in the shallow ground water from both study areas. One sample from the Sheyenne Delta aquifer contained a high concentration of picloram. Agricultural chemicals in both aquifers were stratified vertically and their concentration correlated inversely with ground-water age. The highest concentrations of these chemicals and the youngest ground-water ages were at the water table. Concentrations decreased and age increased with water-table depth. Nitrate concentration varied seasonally over one-half an order of magnitude, though concentrations only repeated seasonally in some shallow ground water.
\end{abstract}

Land-use factors that increased nitrate and herbicide concentrations were greater tilled area, chemical application, irrigation, and cropland contiguity. Hydrogeological factors that increased these concentrations were a deeper watertable (higher oxygen concentration and less organic carbon), larger grain-size and degree of sorting of aquifer material (shorter time in the soil zone and aquifer), and fewer sulfur-containing minerals (lignite and pyrite) composing the aquifer. High rainfall, just before sampling of the Sheyenne Delta aquifer, contributed to the relatively low nitrate and pesticide concentrations in the shallow ground water of this aquifer by raising the water table higher into the soil zone, increasing ponded water (increasing biodegradation), preventing some chemical application (flooded fields), and leaching and then displacing nitrate-rich water downward, beneath new recharge. The shallow ground-water quality measured beneath cropland in these land-use study areas covers a large range. The land-use, hydrogeological, and rainfall factors controlling this quality also control shallow ground-water quality in other surficial aquifers in the Red River of the North Basin. Although not used for drinking water, $43 \%$ of the shallow ground water from the Otter Tail outwash aquifer was above the U.S. Environmental Protection Agency's nitrate maximum contaminant level of $10 \mathrm{mg} / \mathrm{L}-\mathrm{N}$, reducing its potential uses. These high nitrate concentrations do not threaten the Otter Tail outwash aquifer's surface-water bodies with eutrophication however, because significant denitrification occurs beneath riparian wetlands before ground water discharges to surface waters.

\section{Introduction}

The land use over a shallow, surficial aquifer commonly affects the quality of its ground water. The Red River of the North Basin (hereinafter, Red River Basin), located in eastern North Dakota, northwestern Minnesota, and a small part of northeastern South Dakota, is a major agricultural region (fig. 1). The intensive agricultural land use in the basin has caused concerns about its effect on shallow ground-water quality. In recent years, these concerns have increased as irrigation of cropland in the basin has increased. The quality of shallow ground water found beneath areas of cropland in the Red River Basin can vary markedly. In addition to land use, however, hydrogeological and 


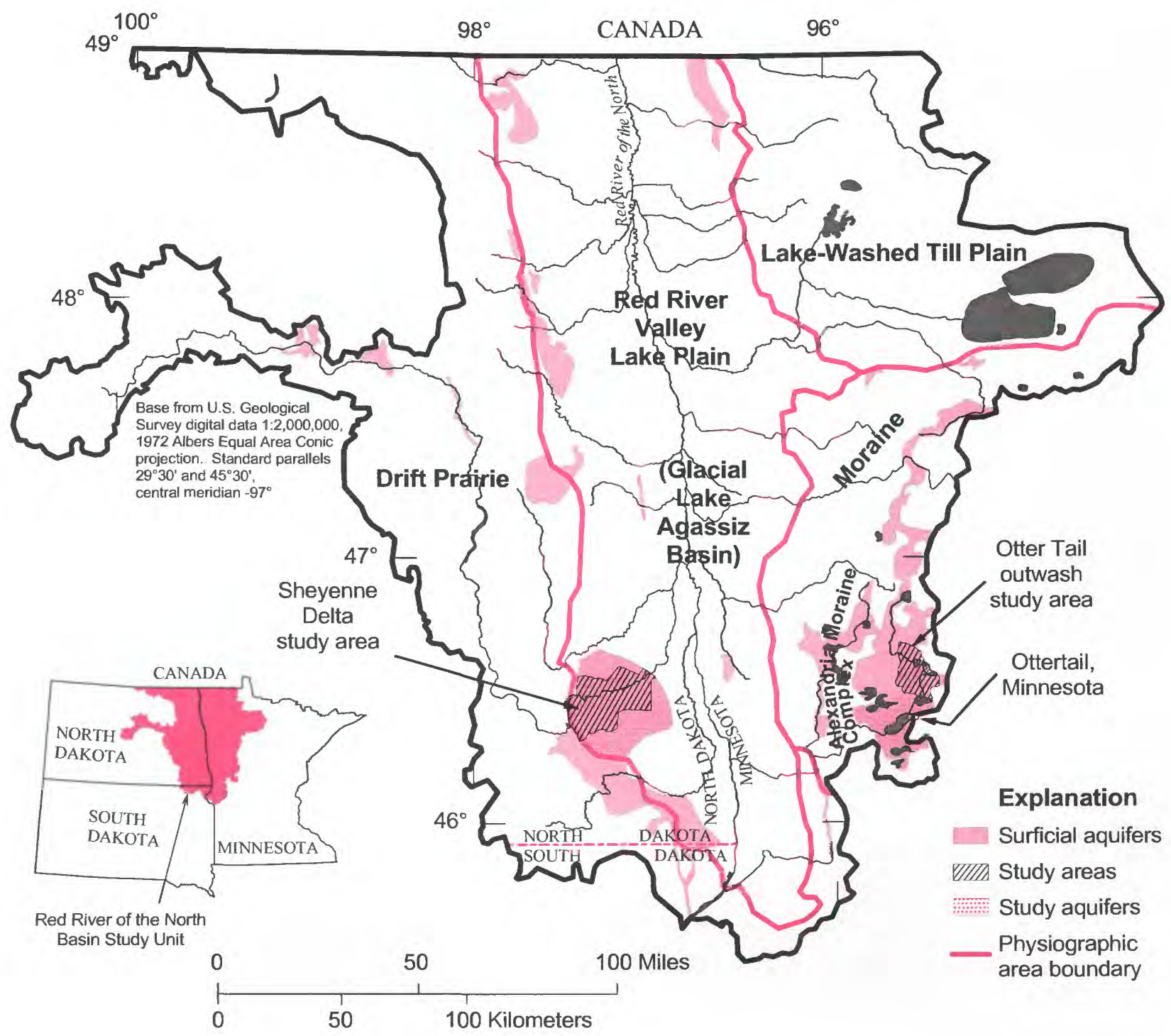

Figure 1-Study area locations, surficial aquifers, and physiographic areas.

[Armstrong, 1982, Baker and Paulson, 1967, Lorenz and Stoner, 1996, and Winter and others, 1969]

weather factors must also be considered when

explaining differences in shallow ground-water quality.

The studies described in this report are part of the U.S. Geological Survey's (USGS) National Water Quality Assessment (NAWQA) of the Red River Basin. The NAWQA goals are to assess the status and trends of quality in a large, representative part of the Nation's fresh-water resources, and to provide a sound, scientific understanding of the primary natural and human factors affecting this quality (Gilliom and others, 1995). These goals are being accomplished through 60 proposed study units, organized around major river basins throughout the Nation. Each study unit has ground- water, surface-water, and aquatic-ecological components that together provide complementary lines of evidence to form a water-quality assessment of the basin as a whole. To address the trend-assessment portion of its mission, the NAWQA is designed as a cyclical process during which 3-year periods of highintensity water-quality sampling alternate with 6-year periods of low-intensity monitoring. The first highintensity period began in the Red River Basin in 1993 and ended in 1995.

The ground-water component of the Red River Basin NAWQA is divided into three spatial scales, each with its own objective (Gilliom and others, 1995). The 
largest-scale study aims to statistically characterize the ground-water quality of the entire basin. The mediumscale studies investigate the relation between land use and ground-water quality over areas of relatively homogenous land use. The smallest-scale studies, nested within the medium-scale studies, better define the water quality along an individual path of ground-water flow, from upland recharge to discharge along streams.

\section{Purpose and Approach}

This report details the findings of the two mediumscale Red River Basin NAWQA land-use studies, and uses data from nested flow-path studies to better explain the spatial and seasonal variability in ground-water quality. It describes and contrasts the ground-water quality in two areas of similar land use above parts of the two largest surficial aquifers in the basin: the Sheyenne Delta study area in southeastern North Dakota and the Otter Tail outwash study area in west-central Minnesota (fig. 1). The report then presents the factors that account for this difference in water quality. Finally, the report suggests how these factors can help anticipate the ground-water quality of other surficial aquifers, affect the potability of shallow ground water, and affect surface-water quality in the basin.

The dominant land use over both aquifers is row-crop production. Because of this similarity, the Sheyenne Delta and Otter Tail outwash aquifers are good areas to test the degree to which factors other than general land use are important in controlling the quality of shallow ground water. Further, because previous researchers (Paulson, 1983, and Reeder, 1972) have documented that both aquifers discharge to the rivers that transect them, these areas are important for assessing groundwater relations with stream quality and ecology. The land-use studies of the Sheyenne Delta and Otter Tail outwash aquifers began in 1993 and 1994, respectively, to assess the effects of row-crop production on the underlying ground-water quality.

This report first describes the methods used to determine concentrations of major inorganic ions, nutrients, filtered dissolved organic carbon (DOC), pesticides, radioactive elements, and volatile organic compounds (VOCs) that characterize the ground-water quality in each aquifer. The water-quality data for each aquifer are then compared with differences in land use, hydrogeology, and rainfall between the two study areas to explain the differences measured in ground-water quality. The vertical and seasonal distributions of selected constituents measured in the flow-path studies clarify human-health implications and provide insights into some of the chemical processes taking place within the aquifers. Analysis concludes with a discussion of how factors shown to affect shallow ground-water quality in the Sheyenne Delta and Otter Tail outwash aquifers may affect water quality in other surficial aquifers.

To characterize water quality in the Red River Basin, the NAWQA investigators divided the basin into four physiographic areas that shared similar geomorphology, soils, and land use (Lorenz and Stoner, 1996). The Red River Basin NAWQA researchers (hereinafter, we) selected the Sheyenne Delta and Otter Tail outwash aquifers as land-use study areas for four reasons. First, because the areas lie within different physiographic areas, differences in water quality between the study areas could relate to differences in physiographic area. Second, because the study areas have similar land use (row-crop production), effects of other important waterquality factors (hydrogeology, weather) may not be overwhelmed by land-use effects. Third, because the study areas overlie parts of the largest surficial aquifers in the basin and these aquifers hydrologically interact with the major rivers that cross them, these are areas in which ground water most affects the water quality of the basin as a whole. Finally, because other surficial aquifers in the basin are similar, conclusions from these land-use studies can help indicate the water quality in these other aquifers.

The Sheyenne Delta study area overlies that part of the Sheyenne Delta aquifer that has surficial drainage to the Sheyenne River and that is not part of the Sheyenne National Grassland (fig. 2). This study area covers 195 $\mathrm{mi}^{2}$ in eastern Ransom and northwestern Richland Counties, North Dakota. The Sheyenne Delta aquifer is an underflow delta deposit built into the southwestern part of Glacial Lake Agassiz by the ancestral Sheyenne River between 11,700 to 10,900 years BP (Fenton and others, 1983). Annual average rainfall in the area was 19.3 inches during the 30-year period from 1966 to 1995 (National Weather Service, 1996). Crop irrigation from the Sheyenne Delta aquifer has increased from $3 \%$ of the total study area in 1984 to $4 \%\left(8.3 \mathrm{mi}^{2}\right)$ in 1991 . During the study, the main land uses were corn, hay and sunflower production, and grazing.

The Otter Tail outwash study area is the area of the Otter Tail outwash aquifer north of Rush Lake. (fig. 2) This study area covers $82 \mathrm{mi}^{2}$ in east-central Otter Tail County, Minnesota. The Otter Tail outwash aquifer was deposited by meandering debris-laden streams flowing from the disintegrating margin of the Des Moines glacial lobe sometime between its maximum extent 14,000 years BP and its rapid retreat into the Glacial 

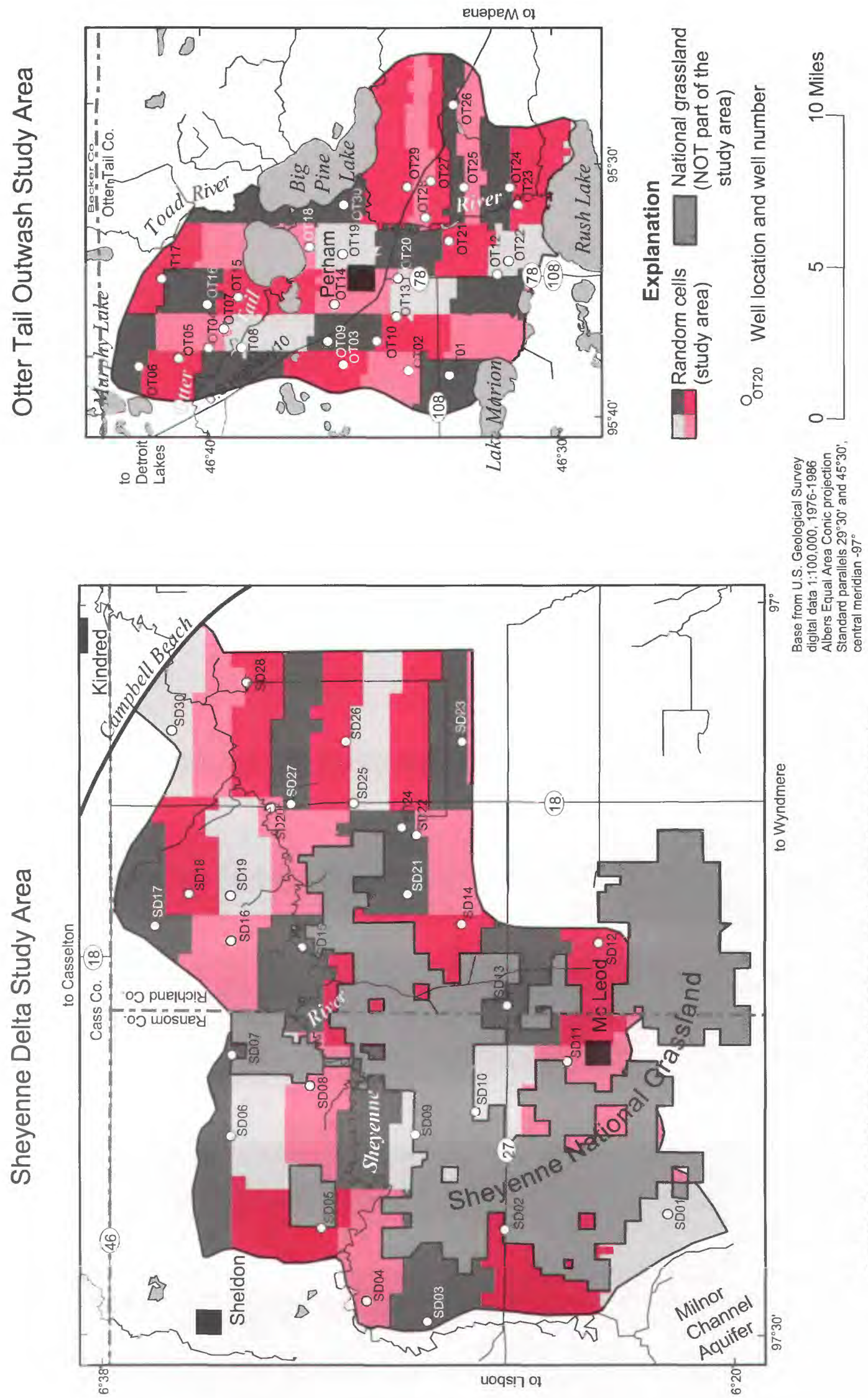

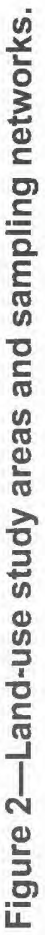




\section{Site Selection, Well Construction, and Sampling-Network Characteristics}

Well sites were selected to obtain a representative sample of shallow ground water over which the dominant land use was row-crop agriculture. The general NAWQA well-site-selection and wellconstruction methods are detailed by Lapham and others (1995). To create the land-use sampling networks, each study area was divided into 30 equal-area cells. A randomly located point in each cell was selected as the sampling site (Scott, 1990). Inventories of existing wells within the study areas identified possible sampling sites. Information about well construction and the geological material penetrated by the well were required for wells to qualify as sampling sites. Further, well owners were to allow sampling and measurement repeatedly over the foreseeable future. Existing wells selected as sampling sites had short screens that were close to the water table, had no confining beds separating the screen from the land surface, and were located as near as possible to the pre-selected randomly located sampling site. If such a well could not be found, we constructed a well to meet these criteria. One cell in each study area contained an installed well that did not produce enough water to sample. No well was sampled in these cells, resulting in water-quality data sets of 29 samples for each study area.

Flow-path transect wells were distributed along a line of ground-water flow inferred from existing water-table maps, within each land-use study area. One to five wells were installed at four or five roughly equally-spaced sites along the line of flow from the recharge area to the discharging stream. Each well nest contained at least one water-table well. Other, deeper wells were distributed evenly between the water table and the first major confining unit at some well sites.

Seasonal sampling networks were established by selecting four water-table wells (three water-table and one deeper well from the Otter Tail outwash study area) from each flow-path transect and four wells from each land-use sampling network. We selected these wells to represent the range of position (recharge area to discharge area) and water quality (areas of high nutrient and pesticide concentration to areas of low concentration) in each land-use study area.

All installed wells were made of 2 in. insidediameter, schedule 40 , flush-threaded, polyvinyl chloride (PVC) pipe with slotted PVC screens. These wells were installed with a hollow-stem power auger and set to intersect the water table, taking into account the normal annual water-table fluctuations. Within the constraints of water-table fluctuations and well- production requirements (at least $0.5 \mathrm{gal} / \mathrm{min}$, steadystate), we installed the shortest well screens possible. All installed land-use and flow-path transect well screens were $4.4 \mathrm{ft}$ long, except for two land-use wells in the Sheyenne Delta study area that had 6.9 and $9.4 \mathrm{ft}$ long screens (see Supplemental Information section, table 14). Five flow-path transect wells had screens that were $9.4 \mathrm{ft}$ long, and three that were $2.3 \mathrm{ft}$ long. After the well was set, auger flights were removed, allowing the aquifer formation to collapse around the screen. Where the aquifer material contained too much fine material to produce an effective filter around a normal screen, twin-concentric PVC screens were installed instead. The interannular space of these screens was filled with washed filter sand before installation. If the aquifer formation did not collapse to at least 1 foot above the screen, washed sand was poured around the screen to that level. Wells then were sealed with at least $2 \mathrm{ft}$ of bentonite pellets before drill cuttings were used to fill the annulus to within $2 \mathrm{ft}$ of land surface. A 7-ftlong, steel protection pipe was set in concrete around the well and closed with a locking cap. Between well sites, the power auger was steam-cleaned to prevent crosscontamination. Both newly constructed and pre-existing observation wells were developed until wells supplied clear water at a rate of at least $0.5 \mathrm{gal} / \mathrm{min}$. No foreign water was introduced into the well except deionized water where necessary for development.

The resulting random land-use sampling networks had median distances from the randomly located points to the sampled wells of $3,920 \mathrm{ft}$ in the Sheyenne Delta study area and $4,126 \mathrm{ft}$ in the Otter Tail outwash study area. The difference between the randomly located points and sampled wells added no known bias into the sampling network. Pre-existing wells in the Sheyenne Delta study area were all observation wells. Those in the Otter Tail outwash study area were observation (3), domestic (3), and commercial (1) wells. Permanentlyinstalled submersible pumps delivered water from all non-observation wells. Figure 3 and table 1 present summary characteristics for wells in these sampling networks at the time of sampling. Table 14 in the Supplemental Information section presents data for the land-use sampling network and flow-path transect wells.

The predominant aquifer texture at a well was estimated by visual and tactile inspection from powerauger cuttings. Land use at a well was estimated from areal photographs and field notes after the land area contributing water to the sampled well was determined. 
Lake Agassiz Basin by about 12,000 years BP (Wright, 1972). Annual average rainfall in the area was 26.8 inches during the 30 year period from 1966 to 1995 (National Weather Service, 1996). Irrigation from the Otter Tail outwash aquifer has increased rapidly in recent years from $23 \%$ of the total study area in 1984 to $27 \%\left(22.5 \mathrm{mi}^{2}\right)$ in 1991 . During the study, corn, hay and beans were the main crops grown.

\section{Previous Studies}

Upham wrote the first description of the Sheyenne Delta in his 1895 treatise on Glacial Lake Agassiz. Early studies of the hydrogeology of the deposit are reviewed by Downey and Paulson (1974) in their evaluation of the hydrological effects of a proposed Sheyenne River dam near Kindred, North Dakota. Harris (1987) mapped in detail the surficial geology of an area including the Sheyenne Delta study area. Paulson (1964) documented substantial ground-water discharge to the Sheyenne River as it crosses the Delta, Strobel and Cowdery (1994) investigated flood effects on the aquifer, and Running (1995a, 1995b, 1996) described and interpreted the geomorphology of the Sheyenne Delta in great detail. Hopkins (1996) also presented a detailed, small-scale hydrological and pedological study of the deltaic deposits. Radig and Bartelson (1994) presented agricultural-chemical concentrations in Sheyenne Delta ground water in their monitoring-program report.

Upham (1885), describing for the first time the geology of Otter Tail County, recognized extensive and thick areas of surficial sands and gravels as well as their hydrogeological importance. Reeder (1972) listed other early investigators of the hydrogeology of the Otter Tail outwash in his study of the aquifer in the Perham area. Smith and Ruhl (1995) presented ground-water-quality data for the aquifer. Stoner and others (1993) and Tornes and Brigham (1993) reviewed the environmental setting and the available ground-water-nutrient data, respectively, for the Red River Basin as a whole. Lorenz and Stoner (1996) compiled maps that explain the basin subdivision and sampling design for the Red River Basin NAWQA. These reviews help to place the landuse-study areas within the regional context of surficial aquifers and general water quality.

\section{Acknowledgments}

Help and cooperation from land owners, local associations, state agencies, the Red River Basin NAWQA Liaison Committee, and the U.S. Forest Service were crucial to the success of this study. I am grateful for their insights and assistance. Much of the data presented here were collected and checked by students and interns; this report is the product of their labor and dedication. Jeff Stoner of the U.S. Geological Survey did the ground-water flow modeling crucial to the land-use data analysis. Dave Lorenz, also of the U.S. Geological Survey, did the land-use data collection and analysis and much of the map preparation for this report. Reviews by Dave Saad and Matt Landon, U.S. Geological Survey, Scott Radig, North Dakota Department of Health, and William Schue, North Dakota State Water Commission, were thorough and insightful.

\section{Study Design and Methods}

The land-use study design focused on assessing landuse effects on shallow ground-water quality in the Red River Basin. The sandy, surficial Sheyenne Delta and Otter Tail outwash aquifers are best suited for this purpose because they are most susceptible to waterquality effects from land use, are relatively simple geologically, and are well-studied. Further, because both aquifers are known to have substantial groundwater/river interaction, these areas permit the integration of ground-water quality with surface-water and ecological quality into one, synthetic assessment of water quality.

Within each study area, 29 wells form a randomlydistributed water-quality sampling network (fig. 2). We constructed 22 wells in each study area to intersect the water table. Well construction and geological data were known for the other seven pre-existing wells used in each network. Within each network, additional wells, installed along a line of general ground-water flow and screened at various depths throughout the aquifer thickness, formed a flow-path transect. These wells provided data on the vertical variation of ground-water quality and on changes in quality as ground water flows from recharge areas to discharge areas. Five sites, containing 9 wells in the Sheyenne Delta study area and six sites, containing 13 wells in the Otter Tail outwash study area composed these flow-path transects. Repeated sampling ( 8 to 13 samples per well over 18 months) at a subset of 8 wells (4 land-use and 4 flowpath transect wells) in each study area showed the seasonal variability in ground-water quality. Ancillary data, such as land use, geology, well construction, weather, and historical ground-water quality, supplied a background with which to explain the ground-water quality data collected. 


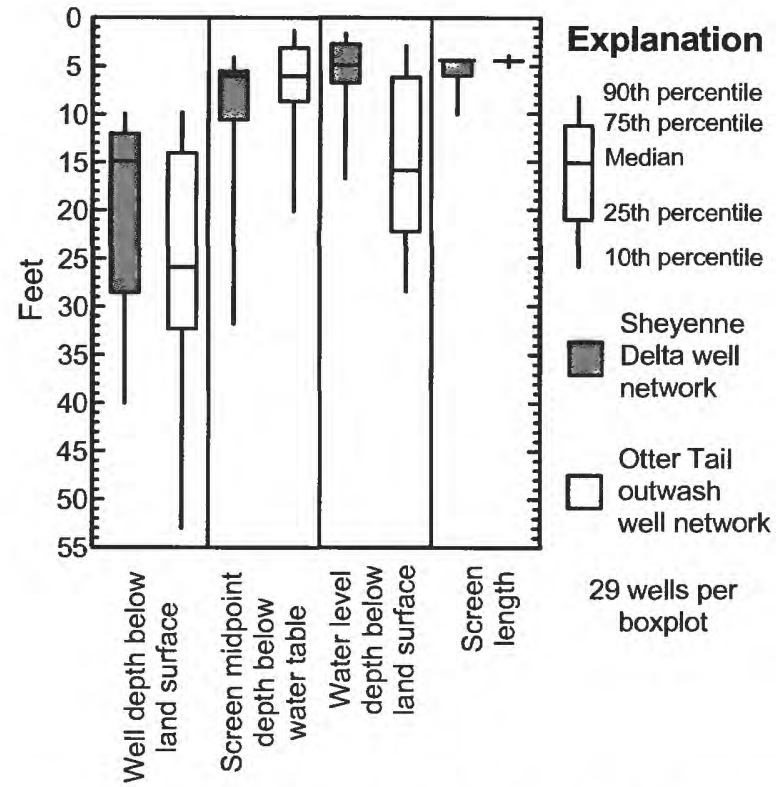

\section{Figure 3-Well characteristics of land-use sampling networks at the time of sampling.}

The procedure for estimating this land use is detailed in the Land-Use Characterization section. Figure 3 shows that the distributed, random process employed to achieve representative samples from each aquifer produced similar distributions in several wellconstruction and land-use details. Well depth, screen length, and most importantly, depth of screen midpoint below the water table have fairly similar distributions, with the last two features having very similar medians, between the Sheyenne Delta and the Otter Tail outwash sampling networks. Wilcoxon rank-sum tests show no statistically significant difference between the two study areas for these network characteristics at the $95 \%$ confidence level (the test is inappropriate for screen length because of the data distribution and was not calculated). Further, characteristics such as land use, aquifer texture, and depth to water, show significant, though sometimes subtle, differences between the two networks. Both aquifer texture and depth to water are statistically different at the $99 \%$ confidence level (using Wilcoxon rank-sum tests). The well characteristics that show similar distributions in both networks cannot explain water-quality differences.

\section{Sample Collection, Analysis, and Quality Control}

One sample was collected from each of the 58 landuse wells during the period from 26 July to 31 August
Table 1.-Well statistics of land-use sampling networks.

[percent of wells (predominant aquifer texture and well use), percent of well contributing areas (land use)]

\begin{tabular}{llcc}
\hline & & \multicolumn{2}{c}{ Study area } \\
\cline { 3 - 4 } & & $\begin{array}{c}\text { Sheyenne } \\
\text { Delta }\end{array}$ & $\begin{array}{c}\text { Otter } \\
\text { Tail } \\
\text { outwash }\end{array}$ \\
\hline Predomi- & Gravel & 0 & 21 \\
nant aquifer & Coarse sand & 10 & 45 \\
texture & Medium sand & 52 & 27 \\
& Fine sand-silt & 38 & 7 \\
\hline Well use & Observation & 100 & 86 \\
& Production & 0 & 14 \\
\hline Land use & Cropland and & & \\
& haying: & & \\
& $\quad$ Non-irrigated & 50 & 47 \\
& $\quad$ Irrigated & 3 & 22 \\
& Grassland and & 8 & 13 \\
& pasture* & & \\
& Forest & 4 & 11 \\
& Wetlands & 0 & 1 \\
& Transportation & 24 & 3 \\
& Farmstead & 11 & 3 \\
\hline
\end{tabular}

* Because the Sheyenne Delta study area does not include the Sheyenne National Grassland, most grassland and grazing land use is on private land. Some small portion of the grassland and grazing land use in the well-contributing area includes the National Grassland because although the well was located within the study area, its contributing area may not have been.

1993 in the Sheyenne Delta study area and during the period from 2 June to 26 July 1994 in the Otter Tail outwash study area. These samples characterize the ground-water quality in each aquifer. Major inorganic ion, nutrient, DOC, and pesticide concentrations were measured in each sample. VOC and radioactive-element concentrations were also measured in the Sheyenne Delta aquifer samples. Each flow-path transect was sampled during one week in June (Otter Tail outwash study area) and July (Sheyenne Delta study area) 1994. Major inorganic ion, nutrient, DOC, and pesticide concentrations were measured in each flow-path transect sample. The Otter Tail flow-path transect was sampled again during August 1995 for the same constituents less the pesticides. The general NAWQA well-sampling procedures are detailed in protocols by Koterba and others (1995). Menheer and Brigham (1997) report the specific application of these protocols to these land-use studies. 
Table 2.-Analytical method references.

\begin{tabular}{lcl}
\hline \multicolumn{1}{c}{ Analyte group } & $\begin{array}{c}\text { Schedule } \\
\text { number }\end{array}$ & \multicolumn{1}{c}{ Method reference } \\
\hline Major ions & 2750 & Fishman, 1993 \\
Nutrients & 2752 & Fishman, 1993 \\
$\begin{array}{l}\text { Dissolved organic carbon } \\
\text { GCMS pesticides }\end{array}$ & 2085 & Wrenshaw and others, 1987 \\
$\begin{array}{l}\text { (gas chromatography/mass spectrometry) } \\
\text { HPLC pesticides }\end{array}$ & 2001 & Zaugg and others, 1995 \\
(high performance liquid chromatography) & 2050 & Werner and others, 1996 \\
VOC & 2070 & Rose and Schroeder, 1995 \\
Radioactive elements & 1810 & U.S. Environmental Protection Agency, 1980 \\
& & American Society for Testing and Materials, 1996a \\
Radon & 1369 & American Society for Testing and Materials, 1996b \\
\hline
\end{tabular}

All wells without permanently installed pumps were sampled with a positive-displacement pump set into the water column just deep enough to extract water at about $0.5 \mathrm{gal} / \mathrm{min}$. These pumps were constructed of only stainless steel, Viton rubber, and Teflon components in order to minimize cross-contamination of water samples. Water was delivered from the pump to an enclosed sampling chamber through Teflon lines and stainless steel valves and connectors such that the water had little contact with the atmosphere and was never under pressure less than atmospheric. This system ensured that the chemical concentrations, and particularly the dissolved-gas composition of the sample water, changed as little as possible during sample collection. Water temperature, specific conductance, and dissolved-oxygen (DO) concentration were continuously monitored prior to sample collection. When these measures stabilized, and three casing volumes of water had been extracted from the well, sample collection began.

Sample containers were chosen and prepared to avoid contamination from the containers, constituents adsorbing to the containers, or constituent degradation. Pump flow rate was adjusted to about $0.5 \mathrm{gal} / \mathrm{min}$ to avoid particulate suspension in the well casing. Samples for all constituents except pesticides, DOC, radon and VOCs were filtered through a 0.45 micrometer $(\mu \mathrm{m})$ nitrocellulose filter. Pesticide samples were filtered through a $0.7 \mu \mathrm{m}$ baked glass-fiber filter. DOC samples were filtered through a $0.45 \mu \mathrm{m}$ silver metal filter. Radon and VOC samples were unfiltered. Sample containers were filled in a consistent order, as quickly as possible, to maintain constant effective filtration (due to filter loading) for each sample type. Mercuric chloride preservative was added to nutrient samples collected during 1993 and 1994. Cation samples were preserved with nitric acid. Nutrient samples collected during 1995 and anion, DOC, pesticide, and VOC samples were stored without preservatives. Nutrient, DOC, pesticide, and VOC samples were shipped to the analyzing laboratory in icefilled coolers the same day that they were collected. Alkalinity was determined in the field by incremental titration.

All samples collected for this study were analyzed at the USGS National Water Quality Laboratory in Arvada, Colorado. Analytes were divided into groups or "schedules" of similar chemicals. Table 2 contains references for these analytical methods. Field decontamination of all equipment between each sample consisted of washing with non-phosphate detergent and local ground water, rinsing with local ground water, rinsing with deionized (DI) water and storing in aluminum foil any equipment that touched sample water. Weekly decontamination of all equipment was the same as field decontamination, with additional rinses of equipment with pesticide-free methanol followed by DI water. Weekly decontamination was also performed after equipment was stored unused longer than two weeks. All these procedures helped produce samples that represented the ground water in the aquifer near each well screen and minimize sampling bias. An extensive quality-control (QC) program demonstrated that these decontamination procedures were successful. 


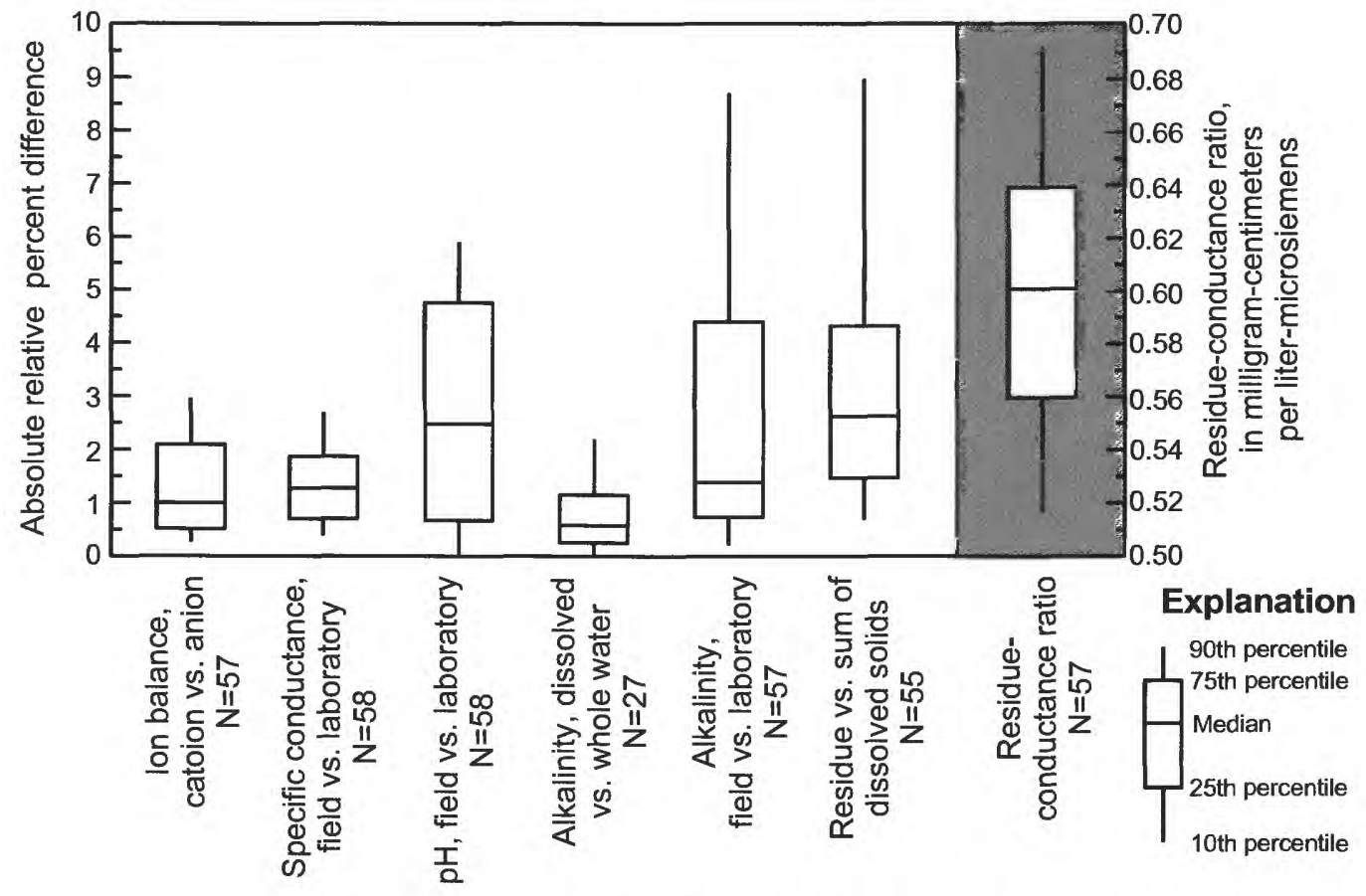

Figure 4-Ground-water quality-control data for land-use samples.

[N, number of samples per boxplot; residue, residue on evaporation; conductance, specific conductance]

The general NAWQA QC program is detailed by Koterba and others (1995) and the specific application of this program to these land-use studies is reported in Menheer and Brigham (1997). Equipment blank samples, field blank samples, replicate samples, and spiked samples gauged the precision and accuracy of the samples collected. The specific purpose of each kind of quality-control sample along with a synopsis of the QC results is presented in table 15 in the Supplemental Information section. All QC samples collected for the Red River Basin NAWQA ground-water program are included in this analysis so that the number of QC samples is great enough to assess adequately the quality of the chemical-concentration data. The results summarized in table 15 indicate that concentrations of chemicals presented in this report are of good quality, with three exceptions. First, although blank-sample data indicate contamination of most DOC samples, it is unlikely that any ground-water samples were contaminated to the degree that blank samples were. The DOC contamination probably came from the detergent and methanol that were used to decontaminate the sampling equipment. When blank samples were collected, some residue of these cleaning agents probably contaminated the 1-2 gallons of blank water passed through the sampling equipment. During normal sampling, many gallons of water passed through the sampling equipment during well purging before a DOC sample was collected. This purging water likely further diluted any DOC remaining in the sampling equipment from the decontamination procedure. Still, because the range of DOC concentrations in blank samples overlap substantially with those of land-use study samples, DOC will not be considered in this report. Second, 12 pesticides analyzed by gas chromatography/mass spectrometry (GCMS) had spike and surrogate recoveries substantially less than $100 \%$. Of these 12 low-recovery pesticides, 3 of them, plus 4 pesticides with good recoveries, had highly variable recoveries. These characteristics raise the possibility of false negative results and a negative bias in the data for these compounds. Third, most of the pesticides analyzed by high performance liquid chromatography (HPLC) had lower recoveries and higher variability than did the pesticides analyzed by GCMS. In the case of the 5 HPLC pesticides with both very low and variable recoveries, these concentrations must be regarded as qualitative. Other pesticide concentrations measured with this method should be considered minima and false negative results are possible. For all pesticides, however, the likelihood of false positives is very low. In this report, no concentrations were changed to compensate for spike and surrogate recoveries. 
Quality-control checks between water properties measured in the field and those measured in the laboratory are shown in figure 4. Sample data presented in this figure consist of the 58 samples from both landuse studies. Field values for specific conductivity, $\mathrm{pH}$, and alkalinity agreed with laboratory values within $11 \%$; the medians ranged from about $1.3 \%$ to $2.5 \%$. Of these measurements, only 2 alkalinity samples (3.5\%), known for volatility, varied by more than $10 \%$. The close agreement between field and laboratory measurements of these water properties demonstrates that water-quality values determined in the laboratory were correctly associated with the sampled wells, and shows the degree of accuracy of these properties. Alkalinity in 27 samples was measured in the field in both dissolved (filtered) and whole water (unfiltered) aliquots to assess the degree to which suspended sediment affected this property. The low median relative difference and variability between dissolved and whole water aliquots shows that filtered samples were adequate to assess both the acid-neutralizing capacity of the water and the bicarbonate and carbonate concentrations in these samples.

Three quality-control checks were calculated to assess the degree to which water-quality measurements are consistent in a sample (fig. 4). The ion balance shows the degree to which the charges of cations measured in a sample are balanced by the charges of anions in a sample.

Ion balance $=\frac{\Sigma \text { cation equivalents }-\Sigma \text { anion equivalents }}{\Sigma \text { cation equivalents }+\Sigma \text { anion equivalents }} \times 100$

Because water is charge-neutral, an ideal analysis of ions dissolved in water should produce an ion balance of zero. Ion balances in all samples are within $6 \%$, with a median of $1 \%$. Residue on evaporation (ROE) is the mass of solids left in a sample after all water is evaporated at $180^{\circ} \mathrm{C}$. If no volatile compounds are present in a sample, ROE should equal the sum of the mass of all ions measured (sum of dissolved solids). The absolute relative difference between ROE and sum of dissolved solids agrees within $22 \%$ for all samples, with a median of about $2.5 \%$. Hem (1989) has observed an empirical relation between ROE and specific conductivity (SC). Generally, ROE divided by SC should be between 0.55 and 0.75 milligram centimeters per liter microsiemens $(\mathrm{mg} \cdot \mathrm{cm} / \mathrm{L} \cdot \mu \mathrm{S})$ in most ground waters. This relation relies on the fact that the conductivity of water is related to its ion concentration. Therefore, because both ROE and SC are measures of ion concentration in water, the relation between the two should be linear and the quotient of the two should be constant. ROE divided by SC (residue-conductance ratio on fig. 4) ranges from 0.4 to $1.0 \mathrm{mg} \cdot \mathrm{cm} / \mathrm{L} \cdot \mu \mathrm{S}$ in these samples, with the median about $0.6 \mathrm{mg} \cdot \mathrm{cm} / \mathrm{L} \cdot \mu \mathrm{S}$; only $3.5 \%$ of the samples fall outside of Hem's general range. These three quality-control checks show a high degree of internal consistency with respect to waterquality measurements of land-use samples.

\section{Land-Use Characterization}

Agricultural-practice information was critical to this analysis of land-use effects on shallow ground-water quality. Ideally, the history of agricultural practices (particularly chemical application and irrigation) in each study area should span the age of the water sampled. Practically, that information is not available. Therefore USGS remote sensing land-use and land-cover data collected during the 1970's and field land-use inventories collected during 1993, 1994, and 1995 serve as the basic agricultural-practices data in this report. These field inventories noted the specific crops grown. Cropland and haying form one category because both land uses can involve chemical application, mechanical harvesting and irrigation. Grassland (including land in the U.S. Department of Agriculture's Conservation Reserve Program) and pasture form another category because these agricultural practices are absent or sparingly applied. Because the Sheyenne National Grassland is not a part of the Sheyenne Delta study area, all grassland and pasture in the study area is on private land. The extent of irrigation was estimated from aerial photographs taken in 1990-91. These estimates match reported irrigated acreage within $2.5 \%$ of the study area (50\% of the irrigated area) for the Sheyenne Delta and $4 \%$ of the study area ( $15 \%$ of the irrigated area) for the Otter Tail outwash study area. Change in irrigation was estimated by comparing the 1991 photographs to photographs taken in 1984-85. The transportation landuse category includes roads and railroads proper and the ditches and rights-of-way adjacent to them. These ditches and rights-of-way may be harvested for hay or grazed.

Chemical applications to fields are difficult to estimate without information from each applier, which was beyond the scope of this report. Nitrogen and phosphorus application rate estimates were calculated by Tornes and Brigham (1993) for each county in the Red River Basin. These estimates are based on 1985 state-wide fertilizer application-rate data, which were apportioned to each county on the basis of percent agricultural land within each county (Alexander and Smith, 1990). Tornes and Brigham (1993) calculated the manure component of nutrient application rates from 1987 county livestock population census statistics assuming a constant nutrient content in animal waste, and that net inter-county waste transfer is negligible. 
The nutrient application rate estimate for the Sheyenne Delta study area is the average of that for Ransom and Richland Counties. We estimated pesticide use in each study area based on the crops grown and pesticide usage statistics from Minnesota (Kelly and Hines, 1992) and North Dakota (Zollinger and others, 1992), and maximum recommended application rates (University of Minnesota Agricultural Extension Service, 1991).

Each sampling network of 29 wells was established to estimate the shallow ground-water quality beneath landuse in the study area. To assess how well each network represented land-use in the study area as a whole, we characterized the land-use in the area most likely to contribute recharge water to each land-use well. The shallow wells used for this study actually obtain water that has seeped through up-gradient parcels of land much smaller in area than the study area. A simple groundwater-flow model used conceptual hydrological and geological factors for the study areas to estimate the upgradient area most likely to contribute recharge to each sampling network well.

To test concepts of ground-water flow near a sampling network well, the computer programs MODFLOW (McDonald and Harbaugh, 1988) and MODPATH (Pollock, 1989) simulated three-dimensional steady-state ground-water flow and travel times, respectively, in each of the aquifers. For each study area, a five-layer model was constructed for a hypothetical $1,000-\mathrm{ft}$ by $5,000-\mathrm{ft}$ rectangular portion of each aquifer with a representative range of horizontal hydraulic gradients. Layer one simulated unconfined conditions and allowed inputs of the average effective recharge rate (total precipitation minus losses from runoff and evapotranspiration). By specifying constant-head cells, one edge of layer one represented a ground-water discharge area, such as a lake or stream. The other three edges of layer one and all edges of the underlying layers were no-flow boundaries. The bottom of layer five also was a no-flow boundary to represent a confining unit below the surficial aquifer. Layers two through five had equal thicknesses and combined with layer one to represent a typical thickness for each aquifer.

Table 3 summarizes the factors incorporated in the model simulations for each study area. A separate generic model was developed for each study area by adjusting the hydraulic properties and effective recharge rate until horizontal hydraulic gradients reasonably matched those reported in previous investigations (Downey and Paulson, 1974, and Reeder, 1972) and determined by water-level measurements in this study. The effects of seasonal withdrawal of ground water from irrigation wells and the sampling network wells were assumed to be negligible for this analysis and therefore were not simulated. Using a realistic range of possible hydraulic conductivity (Lorenz and Stoner, 1996), the backward path-line tracking option of MODPATH computed conservative ground-water travel times and distances. All other factors used in the simulations were within reasonable limits of measured or reported values (Downey and Paulson, 1974; Reeder, 1972; Baker, 1967; and Fetter, 1994).

Estimates of the radius of up-gradient areas of recharge contribution were computed for relatively low and high gradient conditions for each study area using the generic models. Ground-water-flow lines were tracked between a 5-foot depth below the water table (representing the midpoint of most wells used in the study) and the up-gradient water table (table 3 ). Simulations also were made for a 10-foot depth below the water table for low-gradient conditions (highgradient conditions did not exist for the 10-foot depth). The resulting radii varied considerably between the two study areas and the two gradient conditions. The computed time of travel ranged from 2.5 years for the 5foot depth of either gradient condition in the Otter Tail outwash study area to 15.6 years for the 10-foot depth of the low-gradient condition in the Sheyenne Delta study area. These travel times, which were computed for the deepest part of a 5- or 10-foot screen depth, represent the maximum ground-water ages estimated by the models. These travel times compare favorably with ages determined by analyses of chlorofluorocarbons in samples (Puckett and others, 1995) collected from most of the Otter Tail outwash flow-path transect wells.

Model-computed travel times do not account for the time required for water to percolate from the soil surface to the water table. This percolation cannot begin until the soil field capacity is exceeded (becomes saturated), a condition for well-drained sandy soils that commonly occurs only during heavy rains, rainfall coincident with irrigation, or spring snowmelt. A review of precipitation data and water-level hydrographs suggests that a reasonable estimate of the time for water to move from the soil to the water table was from 0.5 to 1 year in both aquifers. This time interval, added to the modelcomputed estimates of time for travel between the water table and the well, results in total estimated travel times, from the land surface to a sampled well, ranging from 0.5 years (immediately adjacent to the well) to 16 years (fig. 5). The midpoint of most sampling intervals for this study was within about $6 \mathrm{ft}$ (median: $6.6 \mathrm{ft}$ ) of the water table under low hydraulic gradient conditions.

Assuming travel time to be the average of that at the top 
Table 3.-Ground-water modeling factors for flow in land-use study areas.

\begin{tabular}{|c|c|c|}
\hline \multirow[b]{2}{*}{ Factor } & \multicolumn{2}{|c|}{ Study area } \\
\hline & Sheyenne Delta & Otter Tail outwash \\
\hline Aquifer thickness ( $\mathrm{ft}$ ) & $64-87$ & $44-49$ \\
\hline Porosity & .35 & .25 \\
\hline Effective recharge rate (feet per year) & .25 & .58 \\
\hline Horizontal hydraulic conductivity range $(\mathrm{ft} / \mathrm{d}$ ) & $5-10$ & $100-240$ \\
\hline Ratio of horizontal to vertical hydraulic conductivity & 10 & 5 \\
\hline \multicolumn{3}{|c|}{ Low horizontal hydraulic gradient conditions } \\
\hline Gradient range & $.0008-.0015$ & $.00019-.00044$ \\
\hline $\begin{array}{l}\text { Radius of influence for } 5 \text {-foot depth below water table (feet) } \\
\text { and maximum travel time [years] computed by model }\end{array}$ & $70-80[8.0]$ & $280-365[2.5]$ \\
\hline $\begin{array}{l}\text { Radius of influence for } 10 \text {-foot depth below water table (feet) } \\
\text { and maximum travel time [years] computed by model }\end{array}$ & $130-160[15.6]$ & $520-750[4.8]$ \\
\hline Radius used to characterize land use ( $\mathrm{ft}$ ) & 160 & 490 \\
\hline \multicolumn{3}{|c|}{ High horizontal hydraulic gradient conditions } \\
\hline Gradient range & $.0015-.011$ & $.00077-.0017$ \\
\hline $\begin{array}{l}\text { Radius of influence for } 5 \text {-foot depth below water table (feet) } \\
\text { and maximum travel time [years] computed by model }\end{array}$ & $385-395[7.6]$ & $550-630[2.5]$ \\
\hline Radius used to characterize land use ( $\mathrm{ft}$ ) & 410 & 660 \\
\hline
\end{tabular}

and at the bottom of the well screen, the total estimated time for water (and possible contaminants) to move from the soil to a typical well in this study was about 4 years in the Otter Tail outwash study area and about 11 years in the Sheyenne Delta study area. These median travel times represent steady-state flow conditions. During the period that the land-use and flow-pathtransect wells were in installed (1993-1994), water levels were rising (fig. 16) in response to precipitation after several years of drought during the late 1980's and early 1990 's. Based on hydrographs that showed water levels near historic highs, wells screens were set to intersect the water table near the screen top in anticipation of lower water levels in the future. Water levels continued to rise however, resulting in relatively deep sampling midpoints and apparently older water. However, much of the water sampled from the watertable wells in these studies was actually very recent recharge (within 2 years of the sampling date) because water levels had been depressed during the preceding drought. The difference in travel times between the study areas does influence the age and therefore land use of some of the wells that were screened somewhat deeper than median depth and were not influenced by the recent recharge just prior to sampling.

Although most wells were in low-gradient areas and had shallow sampling depths (about 6.6 feet below the water table), the model-computed radii used to characterize the land use around the wells were toward the larger end of the range (high gradient, deeper sampling depth) to provide the largest reasonable estimate of the radii. The up-gradient distances for the Otter Tail outwash study area (490 ft for low gradient and $660 \mathrm{ft}$ for high gradient) were larger than the distances used for the Sheyenne Delta study area $(160 \mathrm{ft}$ and $410 \mathrm{ft}$ ). The general ground-water flow directions and hydraulic gradients throughout each study area were estimated from water-table maps constructed from synoptic measurements made at sampled wells during this study.

Based on the distances estimated from the flow models and the ground-water-flow direction, 90-degree sectors delineated the recharge area to each well. Each 90-degree sector was large enough to encompass the true ground-water-flow direction given seasonal 


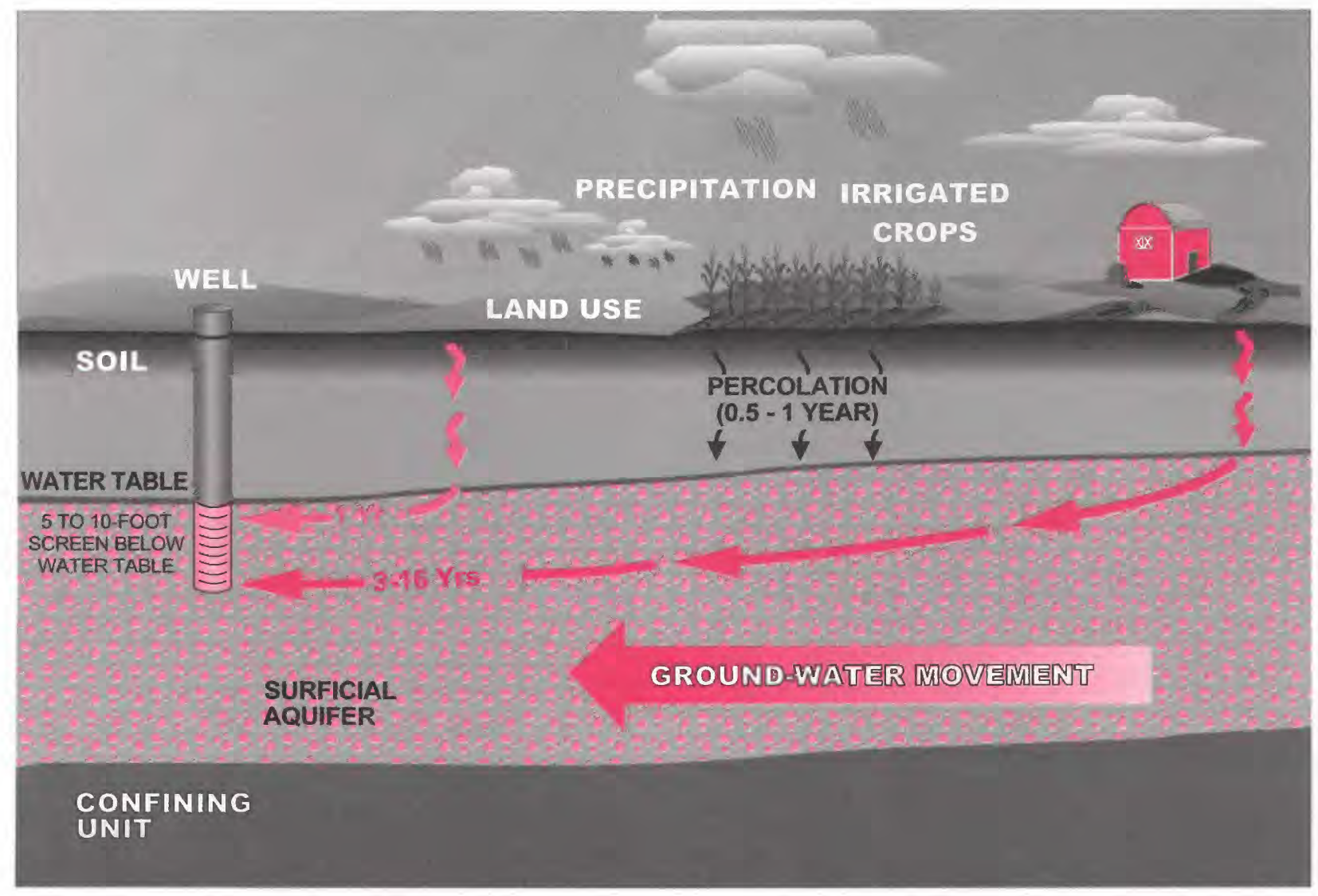

Figure 5-Conceptual ground-water recharge and flow to a well screened at the water table.

variability and direction uncertainty. Where the flow direction was uncertain, such as on recharge mounds, full 360-degree circles delineated the recharge areas. The location of a well fixed the point of its sector, with the estimated ground-water-flow direction from the upgradient direction bisecting the sector. The radius of the sector was fixed at the distance determined by the flowmodel analysis for the appropriate hydraulic gradient and well-screen length. The proportion of area within this recharge area was measured for each land-use category. The resulting comparison of land use within each study area and land use within the contributing areas of each of the land-use sampling networks is presented in table 4.

The percentages vary by less than $10 \%$ of the study area except for the non-irrigated cropland and haying and transportation land-use categories in the Sheyenne Delta study area. Most wells installed in both study areas tended to be close to roads so that their presence would not interfere with land use. Well locations close to roads over represent the transportation land use. Because the radius of the well contributing area is smaller in the Sheyenne Delta study area, the transportation land use is more over represented than in the Otter Tail outwash study area, mostly at the expense of the non-irrigated cropland and haying, and grassland and pasture land uses. This over representation in both study areas means that the contribution of the transportation land use to water quality will be overestimated. Much of the transportation land-use category is composed of ditches and rights-of-way that are often used for wild-hay production or grazing, land uses common to the under represented grassland and pasture category. Therefore, the over representation of transportation land use, particularly at the expense of grassland and pasture land use in the Sheyenne Delta study area, may not greatly bias the overall water quality based on samples from these networks, because the detailed land uses in both categories are similar. Regardless, water-quality effects from chemicals applied to transportation land use areas will be overestimated in samples from both study areas. The effects from non-irrigated cropland and haying, and grassland and pasture land uses will be underestimated in the Sheyenne Delta study area. Because most 
Table 4.-Land-use comparison of land-use study areas.

[in percent of total area]

\begin{tabular}{|c|c|c|c|c|}
\hline \multirow[b]{2}{*}{ Land use } & \multicolumn{2}{|c|}{ Sheyenne Delta } & \multicolumn{2}{|c|}{ Otter Tail outwash } \\
\hline & Study area & $\begin{array}{l}\text { Well contributing } \\
\text { area }\end{array}$ & Study area & $\begin{array}{l}\text { Well contributing } \\
\text { area }\end{array}$ \\
\hline \multicolumn{5}{|l|}{ Cropland and haying: } \\
\hline Non-irrigated & 60 & 42 & 46 & 43 \\
\hline Irrigated & 4 & 3 & 27 & 19 \\
\hline Grassland and pasture* & 25 & 17 & 8 & 15 \\
\hline Forest & 5 & 4 & 11 & 6 \\
\hline Wetlands & 4 & 0 & 4 & 0 \\
\hline Transportation & 1 & 26 & 1 & 9 \\
\hline Farmstead & 1 & 8 & 2 & 6 \\
\hline Urban & 0 & 0 & 1 & 2 \\
\hline
\end{tabular}

agricultural chemicals are applied to cropland and haying areas, and these areas are underrepresented, concentrations of agricultural chemicals in shallow ground water in the Sheyenne Delta aquifer may be underestimated. The herbicide picloram is commonly applied to control leafy spurge in grassland and pasture areas, however, and its concentration in shallow ground water may be underestimated as a result of the under representation of grassland and pasture areas.

Generally, however, this comparison (table 4) demonstrates that the contributing areas to the wells sampled were representative of the study area land use as a whole.

\section{Description of Study Areas}

Both the Sheyenne Delta aquifer and the Otter Tail outwash aquifer are deposits of surficial sand that can be greater than $115 \mathrm{ft}$ thick. Generally, rain and melted snow recharge both aquifers over nearly their entire surface area and ground water discharges to local surface water bodies, particularly the main rivers. Ground water withdrawn from the surficial aquifer irrigates portions of both study areas. This irrigation is both a source of discharge from the aquifers and a possible source of recharge by return flow. Both aquifers are underlain by thick, clay-rich deposits of glacial till or lake sediments.

\section{Hydrogeology of the Sheyenne Delta Aquifer}

The Sheyenne Delta aquifer is not a classic "Gilbertstyle" delta, but an underflow fan deposit constructed by Glacial River Sheyenne as it flowed into the southwest margin of Glacial Lake Agassiz (Brophy and Bluemle, 1983, Fenton and others, 1983). The Glacial Lake Agassiz Basin is approximately coincident with the Red River Valley Lake Plain physiographic area (fig. 1). An underflow fan forms when the river supplying sediment to the fan is so sediment laden that it flows as a turbidity current along the bottom of the water body it is entering. This style of delta sedimentation produces wedgeshaped deposits that continually grade from gravel near the river's mouth to clay near the fan edge rather than the classic deposits of bottomset, foreset, and topset beds described by Gilbert (1885). The fan formed during the Cass and Lockhart phases of Glacial Lake Agassiz from about 11,700 to 10,900 years BP (Fenton and others, 1983). It is generally composed of many fining-upward sequences of sands, silts and clays. Two minerals differentiate the Sheyenne Delta deposit from the Otter Tail outwash. Cuttings recovered during well drilling show that pyrite from Cretaceous shales and lignite comprise part of the larger-than-silt fractions of the deposit. The entire fan deposit is coarser in the southwest (fine to very fine sand) and at the surface and, as a whole, the fining-upward sequences become generally finer downward and to the northeast, where they become mostly silt and clay (Downey and Paulson, 1974). After Glacial Lake Agassiz first abandoned its 
southern outlet at the beginning of the Moorhead Phase about 10,900 years BP, the fan was subaerially exposed. Glacial River Sheyenne deeply incised a trench up to a mile wide and $90 \mathrm{ft}$ deep into the fan, but did not cut completely through it. The present-day Sheyenne River now occupies this same valley, meandering within it.

The surface of most of the fan is covered by an aeolian sand sheet several feet thick (Running, 1996, Harris, 1987). Over much of the fan, this sand sheet has developed into low dunes less than $33 \mathrm{ft} \mathrm{high}$, with high dunes $33 \mathrm{ft}$ to $66 \mathrm{ft}$ high forming within 1.25 miles of each side of the Sheyenne River. Aeolian sands are also found in the Sheyenne Delta river trench. These aeolian sediments appear to be alluvial delta sands, reworked into dunes during drier periods of the middle part of the Holocene Epoch. Running (1996) suggests that the high dunes may have formed from alluvial sands in the river trench during dry periods from the middle to late part of the Holocene.

As a whole, these fan and aeolian deposits form one hydrogeological unit: the Sheyenne Delta aquifer. However, the deposit is stratigraphically variable, reflecting the complexity of its formation. Downey and Paulson (1974) determined the aquifer to be 49 to $140 \mathrm{ft}$ thick, averaging $97 \mathrm{ft}$. Hydrogeological properties of the aquifer vary somewhat systematically with the coarseness of the deposits. Hydraulic conductivity ranges from $35 \mathrm{ft} / \mathrm{d}$ in the southwestern part of the aquifer to $1 \times 10^{-3} \mathrm{ft} / \mathrm{d}$ in the northeastern part (Downey and Paulson, 1974).

Geomorphically, the Sheyenne Delta aquifer is a nearly flat plain covering $842 \mathrm{mi}^{2}$ of the Glacial Lake Agassiz Basin (fig. 1). It is bounded on its west and south sides by till that hydrologically separates it from the Milnor Channel aquifer to the southwest (see fig. 2). On the north and east sides, the aquifer grades into finegrained deposits of Glacial Lake Agassiz and ends at a wave-cut scarp of the lake's Campbell Beach stage. This scarp merges imperceptibly with the lake-basin edge at Campbell Beach to the south and the aquifer edge is difficult to delineate in this area. The Sheyenne River trench (valley) cuts the aquifer into a north and a south flow system, both of which are unconfined. Each system has a high hydraulic-head region in its central upland area and low areas at the Sheyenne River trench and the Campbell Beach scarp. USGS water-level measurements indicate that ground water flows from these upland areas to areas of low hydraulic head, but in some areas is diverted by drainage ditches and ephemeral streams that are concentrated in the lower hydraulic-conductivity areas of the northeast. Ground water commonly discharges directly to the Sheyenne
River or in springs along the Sheyenne River trench and the Campbell Beach scarp. Water levels in the Sheyenne Delta aquifer are generally less than $15 \mathrm{ft}$ below land surface, except beneath the hills near the river trench and Campbell Beach scarp where it is as much as $65 \mathrm{ft}$ deep. Long-term and annual water-level fluctuations were about $6.5 \mathrm{ft}$ over the last 35 years (fig. 16). The fine-grained tills or Lake Agassiz lacustrine deposits that underlie the Sheyenne Delta aquifer are, themselves, underlain by the consolidated Dakota aquifer. Although the Sheyenne Delta aquifer is hydraulically separated from lower aquifers, many wells are completed in the underlying Dakota aquifer, and flow under artesian pressure with water high in dissolved solids. These flowing wells often form surrounding wetlands, recharging the Sheyenne Delta aquifer locally with water of poorer quality.

\section{Hydrogeology of the Otter Tail Outwash Aquifer}

The Otter Tail outwash aquifer is an intramorainal outwash plain of Des Moines glacial lobe material located just east of the central part of the Alexandria Moraine Complex. This moraine complex forms the western edge of the Moraine physiographic area (fig. 1). The outwash plain formed as sediment-laden outwash streams flowed from the east side of the Des Moines glacial lobe as it stood near its maximum extent and filled the Glacial Lake Agassiz Basin about 16,000 to 14,000 years BP (Goldstein, 1985). During that time (the Bemis and/or Pine City phases of the lobe), Des Moines lobe ice had just crossed the ice-cored Alexandria Moraine Complex from the west, depositing thin tills and issuing outwash streams. As these streams braided across the lowlands east of the moraine, sands, some gravels, and some clay lenses were deposited across much of eastern Otter Tail County. As the streams coalesced, they carried the finer-grained sediments farther east. The outwash was deposited upon a low-relief stagnation moraine just east of the main Alexandria Moraine Complex. This stagnation moraine grades eastward into the Wadena drumlin field about 8 miles east of the study area. Both the moraine and drumlin field were deposited during the Hewitt phase (mid-Wisconsinan) of the Wadena glacial lobe. At the time that the Otter Tail outwash was deposited by Des Moines lobe outwash streams upon Hewitt till deposits, buried stagnant ice was plentiful within it. After the outwash sands were deposited, these ice blocks melted, forming the abundant lakes and wetland depressions common throughout the area (Goldstein, 1985). 
Because only the northern part of this outwash deposit is addressed in this study, all subsequent descriptions will pertain only to that half of the deposit north of Rush Lake, near Perham, Minnesota (fig. 2). This part of the deposit is hydraulically separated from the southern part by a surface-drainage system extending from Lake Marion, in the southwestern part of the study area, along tributaries to Rush Lake in the southeast. The Otter Tail outwash aquifer is underlain and surrounded on nearly all sides by till of the Wadena lobe. The west side of the deposit abuts till of the Des Moines lobe. Based on grain-size distribution, these tills are effective confining materials. The Wadena lobe (Hewitt) till is variable in grain size, ranging from 50 to $80 \%$ sand, 12 to $30 \%$ silt, and 3 to $20 \%$ clay. It becomes finer and more poorly sorted westward toward the former Wadena lobe ice margin near the Alexandria Moraine Complex in eastern Otter Tail County. Des Moines lobe till is much more clay rich (30-44\%) (Goldstein, 1985). Therefore, the till increases in hydraulic conductivity from west to east. The outwash deposited within this till is composed mostly of fine to coarse, fairly well-sorted sand, but also some gravel and clay lenses. It is generally about $60 \mathrm{ft}$ thick, but is over $100 \mathrm{ft}$ thick in places (Reeder, 1972). The Otter Tail outwash is a relatively flat plain, pocked by kettle lakes and wetlands, abandoned drainage channels now filled with wetlands, and three large lakes connected together by the Otter Tail River. An exception to this geomorphology is an area of till and ice-contact stratified deposits along Minnesota State Highway 108 south of Perham (fig. 2). This area is a finger of stagnation topography, partly buried by outwash, extending from the moraine west of the aquifer nearly to the Otter Tail River. The physical shape of the coarsegrained materials in this deposit and their hydraulic connection to the outwash deposits is unknown. In this study, I have treated these ice contact deposits as part of the aquifer. However, these deposits probably interrupt and retard flow locally in aquifer. The aquifer ends abruptly along its northeastern edge between Murphy Lake and the Toad River at a fosse (fig. 2), formed as outwash was deposited against a part of the stagnating Wadena lobe. This part of the aquifer stands higher than the stagnation topography to the northeast. Water levels are locally high in the part of the aquifer adjacent to the fosse ensuring that ground-water flow in minor interfingered ice-contact stratified deposits along the fosse is away from the Otter Tail aquifer.

The Otter Tail outwash aquifer is generally unconfined. However, clay lenses appear to be extensive enough to develop confined conditions locally at depth. Reeder (1972) reported the saturated thickness to be as great as $80 \mathrm{ft}$ and hydraulic conductivity (based on 3 aquifer tests and aquifer texture) to be generally about $180 \mathrm{ft} / \mathrm{d}$. Aquifer thickness tends to be greatest along the Otter Tail River through the center of the aquifer area. Ground-water flow is generally from the higher elevations of the moraines on the west, north, and east sides of the aquifer toward the Otter Tail River-lake chain in the center. Wetlands, lakes and streams appear to be in hydraulic connection with the ground water. Recharge to the aquifer occurs over much of its area from snowmelt, direct precipitation, and possibly irrigation return flow. Reeder (1972) suggests that a very small amount of ground water may enter the aquifer from adjacent ice contact stratified deposits and tills in the northwest corner of the aquifer. Discharge is to the Otter Tail River, lakes, wetlands, wells, and through evapotranspiration. Water levels in the Otter Tail outwash aquifer generally range from 5 to $30 \mathrm{ft}$ below the land surface, but may reach depths of $70 \mathrm{ft}$ (Reeder, 1972). Shallower areas include those near wetlands and water bodies, and the area north of Lake Marion. Long-term and annual water-level fluctuations have been about $5 \mathrm{ft}$ over the last 25 years (fig. 16).

\section{Land Use}

The land use on both study areas was primarily cropland and haying (table 4) - 64\% of the Sheyenne Delta, 73\% of the Otter Tail outwash. The major crops were corn, hay, and sunflowers in the Sheyenne Delta study area and corn, hay, and soybeans in the Otter Tail outwash study area (table 5). Grazing also was a major land use in the Sheyenne Delta study area. Both study areas had irrigated cropland, but it was much more widespread, and the percentage of cropland under irrigation increased more from 1984-91, in the Otter Tail outwash study area (table 5). Privately-owned grassland and forest comprised the other major land uses in both study areas (table 4), but this grassland was more widespread in the Sheyenne Delta study area and forest was more widespread in the Otter Tail outwash study area, reflecting the dryer climate to the west. Cropland is much less contiguous in the Sheyenne Delta study area because large areas of grasslands (both private and public) are interspersed within and around it (fig. 2)

Nutrient application estimates for each study area are listed in table 6. Application rates of both nitrogen and phosphorus are more than twice as large in the Otter Tail outwash study area as they are in the Sheyenne Delta study area. Beef production is an important land-use in the Sheyenne Delta study area, however. Therefore, the nutrient input to the study area from manure should be higher in the Sheyenne Delta study area than the countywide averages in table 6 indicate, although not so high 
as to eliminate the difference in total nutrient application between the two study areas.

Table 5.-Average crop and irrigation area for land-use study areas during 1992-93. [in percent cropland area; because not all crops are listed, percentages do not sum to 100 .]

\begin{tabular}{lcc}
\hline \multicolumn{1}{c}{ Land Use } & $\begin{array}{c}\text { Sheyenne } \\
\text { Delta }\end{array}$ & $\begin{array}{c}\text { Otter Tail } \\
\text { outwash }\end{array}$ \\
\hline Corn & 39 & 34 \\
Soybeans & 6 & 14 \\
Sunflowers & 15 & 2 \\
Hay & 10 & 20 \\
Grazing & 19 & 6 \\
Small grains & 7 & 10 \\
Potatoes & 2 & 5 \\
\hline 1984 cropland irrigation & 3 & 23 \\
1991 cropland irrigation & 4 & 27 \\
\hline
\end{tabular}

The most-used agricultural herbicides in the study areas are listed in table 7 although other pesticides were also used. Picloram, in particular, was widely used in the Sheyenne Delta study area to control leafy spurge in pastures and grazing areas. Use of picloram is low statewide and, therefore, does not appear in table 7. The total rate of all herbicides applied in the Sheyenne Delta study area was (1.79 pounds per acre per year) $17 \%$ less than it was in the Otter Tail outwash study area (2.16 pounds per acre per year). Of the 31 herbicides listed in table 7,18 were quantified in ground-water samples from the land-use study areas. These 18 herbicides account for more than $98 \%$ of the total herbicide mass applied yearly. All but two herbicides used in the study areas at rates greater than 0.009 pounds per acre per year were quantified. These non-quantified herbicides were glyphosate ( 0.0151 pounds per acre per year) in the Sheyenne Delta study area and dichlofop $(0.0092$ pounds per acre per year) in the Otter Tail outwash study area.

Insecticide use was much more difficult to estimate accurately. Because insecticide use is relatively local, addressing individual insect infestations, the state-wide statistics used to estimate pesticide use produced either gross underestimates in areas where insecticides were used, or gross overestimates in areas where they were not used. Seven insecticides, applied to two crops grown in the study areas are in common use, however. Esfenvalerate and ethyl parathion were often used on sunflowers most commonly grown in the Sheyenne Delta study area. Methyl-azinphos, carbosulfuran, endosulfan, esfenvalerate, methamidophos, and phorate were used on potatoes most commonly grown in the Otter Tail outwash study area. Of these seven insecticides, four were quantified in these studies: esfenvalerate, ethyl parathion, methyl-azinphos, and phorate.

Table 6. - Estimated average nutrient use in landuse study areas.

[in pounds per acre per year]

\begin{tabular}{|c|c|c|}
\hline & $\begin{array}{c}\text { Sheyenne } \\
\text { Delta }\end{array}$ & $\begin{array}{l}\text { Otter Tail } \\
\text { outwash }\end{array}$ \\
\hline \multicolumn{3}{|c|}{ Nutrients } \\
\hline Chemical nitrogen ${ }^{1}$ & 19 & 32 \\
\hline Manure nitrogen ${ }^{2}$ & 4 & 20 \\
\hline Total nitrogen & 23 & 52 \\
\hline Chemical phosphorus ${ }^{1}$ & 4 & 6 \\
\hline Manure phosphorus ${ }^{2}$ & 1 & 5 \\
\hline Total phosphorus & 5 & 11 \\
\hline
\end{tabular}

${ }^{1}$ based on 1985 state-wide fertilizer application rate data apportioned to the percentage of agricultural land in each county (Tornes and Brigham, 1993).

${ }^{2}$ based on 1987 county livestock population statistics (Tornes and Brigham, 1993).

\section{Climate}

Stoner and others (1993) summarized the climate of the Red River Basin as continental, noting that a subhumid to dry-subhumid gradient exists from east to west. The continental climate implies large ranges and rapid changes in temperature and precipitation, due to the lack of moderating oceans and mountainous airmass barriers. These geographic characteristics are also responsible for large interannual climate variability. Both study areas lie at about $46.5^{\circ}$ north latitude, but the Sheyenne Delta study area is 90 miles west of the Otter Tail outwash study area. The median precipitation during 1966-95 resulting from this difference in longitude was 6.7 inches less in the Sheyenne Delta than in the Otter Tail outwash study area (National Weather Service, 1996, McLeod, North Dakota and Otter Tail, Minnesota). The Sheyenne Delta study area was also slightly warmer (median: $3^{\circ} \mathrm{F}$ ) than the Otter Tail outwash study area in summer and winter during the same period. The climate difference between the two areas is reflected in the native biological differences between the areas. The Sheyenne Delta study area was a tall bluestem prairie (big and little bluestem, switch grass and Indian grass) (Kuchler, 1964) which survives to some degree in the Sheyenne National Grassland. 
Upham (1883) mapped the Otter Tail outwash study area also as prairie, but surrounded by hardwood and conifer forests on the morainal uplands.

Table 7.-Estimated average

herbicide ${ }^{1}$ use in land-use study areas.

[in pounds per acre per year; herbicides in red were not sampled in these studies.]

\begin{tabular}{lcc}
\hline & $\begin{array}{c}\text { Sheyenne } \\
\text { Delta }\end{array}$ & $\begin{array}{c}\text { Otter Tail } \\
\text { outwash }\end{array}$ \\
\hline EPTC & 0.5571 & 0.5783 \\
Cyanazine & .2130 & .3505 \\
Alachlor & .1550 & .2545 \\
Dicamba & .1884 & .2052 \\
2,4-D & .1136 & .1225 \\
\hline Propachlor & .0070 & .1224 \\
Atrazine & .0226 & .0904 \\
Trifluralin & .1089 & .0893 \\
Metolachlor & .1413 & .0802 \\
MCPA & .0324 & .0785 \\
\hline Bentazon & .0302 & .0472 \\
Pendimethalin & .0213 & .0397 \\
Ethalfluralin & .1319 & .0363 \\
Bromoxynil & .0247 & .0233 \\
Acifluorfen & .0072 & .0119 \\
\hline Triallate & .0040 & .0096 \\
Diclofop & .0024 & .0092 \\
Metribuzin & .0019 & .0044 \\
Sethoxydim & .0052 & .0030 \\
Imazamethabenz & .0026 & .0021 \\
\hline Imazethapyr & .0003 & .0016 \\
Difenzoquat & .0006 & .0016 \\
Glyphosate & .0151 & .0008 \\
Lactofen & .0005 & .0005 \\
Clopyralid & .0000 & .0004 \\
\hline Fluazifop-p & .0003 & .0003 \\
Tribenuron & .0002 & .0002 \\
Fenoxaprop & .0004 & .0001 \\
Thifensulfuron & .0000 & .0001 \\
Nicosulfuron & .0030 & .0000 \\
Metsulfuron & .00004 & .0000 \\
\hline Total herbicides applied: & 1.79 & 2.16 \\
\hline & & \\
\hline
\end{tabular}

${ }^{1}$ based on pesticide usage statistics from Minnesota (Kelly and Hines, 1992) and North Dakota (Zollinger and others, 1992) and from maximum recommended application rates (University of Minnesota Agricultural Extension Service, 1991)

\section{Ground-Water Quality Beneath Cropland}

\author{
Water Quality
}

The 29 shallow ground-water (hereinafter, water) samples collected from each study area confirm historical water-quality data, expand the list of constituents analyzed, and form statistically valid, comparable characterizations of the water in each aquifer. These characterizations may be different, however, from those drawn from historical water-quality data because many of the historical data were collected from domestic, irrigation or monitoring wells which have long open intervals, are open to the lower parts of the aquifer or both. Water from both aquifers was rather dilute, about $340 \mathrm{mg} / \mathrm{L}$ residue-on-evaporation, and had similar specific conductance (about $575 \mu \mathrm{S} / \mathrm{cm}$ ) and $\mathrm{pH}$ (about 7.55). During the respective sampling periods, Sheyenne Delta water was generally anoxic (DO median: $<0.1 \mathrm{mg} / \mathrm{L}$, average: $0.41-0.48 \mathrm{mg} / \mathrm{L}$ ) and Otter Tail outwash water generally oxygenated (DO median: $3.6 \mathrm{mg} / \mathrm{L}$, average: $4.5 \mathrm{mg} / \mathrm{L}$ ). Both waters were dominated by calcium, magnesium and bicarbonate ions (fig. 6). Some water in the Sheyenne Delta aquifer contained major amounts of sulfate and sodium (fig. 6 , SD01, SD06, SD26), possibly derived from deeper ground water from the underlying Dakota Sandstone. This feature, absent from the Otter Tail outwash aquifer, shows that differences in ground-water quality may be related to physiographic area. Because the Dakota aquifer, which contains poor-quality water, only subcrops in the Red River Valley Lake Plain (Glacial Lake Agassiz Basin) physiographic area, only the water quality in surficial aquifers in this area could be affected by discharge from this deeper aquifer.

\section{Nutrients}

Water from the two study areas contained significantly different nitrogen concentrations, but not phosphorus concentrations. Previous investigators (Reeder, 1972; Tornes and Brigham, 1993) noted that ground water in the Otter Tail outwash aquifer can contain high nitrate concentrations, occasionally greater than the U.S. Environmental Protection Agency (USEPA) (1996) drinking water standard of 10 milligrams of nitrogen per liter water $(\mathrm{mg} / \mathrm{L}-\mathrm{N})$. Nitrate-plus-nitrite, nitrite, ammonia-plus-organic nitrogen, and ammonia, each reported as $\mathrm{mg} / \mathrm{L}-\mathrm{N}$, were the four forms of nitrogen determined in this study. By subtraction, nitrate and organic nitrogen concentrations were calculated. One nutrient sample from the Otter Tail outwash study area was ruined during analysis leaving 28 samples to form the nutrient characterization for this water. 


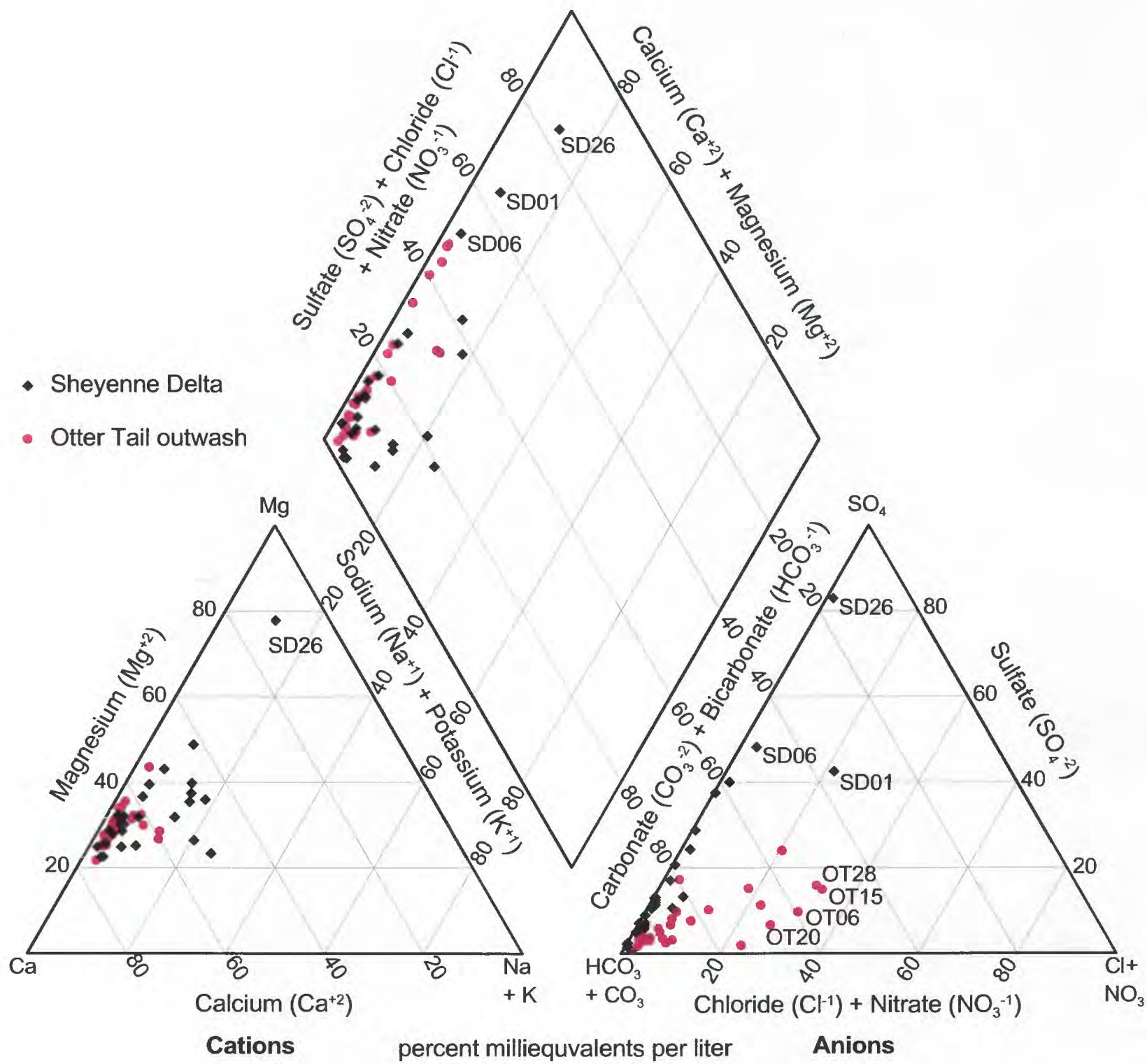

Figure 6-Major ion chemistry of shallow ground water from land-use study areas.

The median concentration of nitrate in Otter Tail outwash water was more than two orders of magnitude greater than it was in Sheyenne Delta water (fig. 7, table 8 ) and highly significantly different (Wilcoxon ranksum test $p$-value of 0.0001 ). The maximum concentration was about one order of magnitude higher. Madison and Brunett (1984) have shown that concentrations of nitrate in ground waters up to $3 \mathrm{mg} / \mathrm{L}$ $\mathrm{N}$ are likely to be natural. Ground waters with concentrations from 3 to $10 \mathrm{mg} / \mathrm{L}-\mathrm{N}$ are somewhat affected by additions of nitrogen from human activities. Ground waters with concentrations above 10 $\mathrm{mg} / \mathrm{L}-\mathrm{N}$ are substantially affected by nitrogen from human activities. More than $63 \%$ of water from the Otter Tail outwash aquifer showed some influence of nitrogen from human activities. Only $3 \%$ of Sheyenne Delta water showed such influence (fig. 8). Further, $43 \%$ of water from the Otter Tail outwash aquifer exceeded a nitrate concentration of $10 \mathrm{mg} / \mathrm{L}-\mathrm{N}$. The areal distribution of nitrate in water from either study area showed no obvious pattern (fig. 8). Cowdery and Goff (1993) found a spatial trend in historical nitrate data from the Sheyenne Delta aquifer, however. Nitrate concentrations were highest in water from the 
southwestern part of the aquifer, where irrigation density and hydraulic conductivity of the aquifer are also highest, and lowest in water from the northeastern part. Ammonia concentrations, while low, were significantly higher (Wilcoxon rank-sum test p-value of 0.0003 ) and more variable in Sheyenne Delta water than in Otter Tail outwash water. The median concentration was twice as high in Sheyenne Delta water and the $75^{\text {th }}$ percentile concentration was more than seven times as high. Nitrite and organic nitrogen concentrations were not significantly different (Wilcoxon rank-sum test pvalue of 0.89 and 0.12 , respectively) between waters from the study areas (table 8). Nitrite concentrations in water from both aquifers were very low $(0.09 \mathrm{mg} / \mathrm{L}-\mathrm{N}$ maximum), whereas $75 \%$ of organic nitrogen concentrations in water from both aquifers were less than the detection limit of $0.2 \mathrm{mg} / \mathrm{L}-\mathrm{N}$.

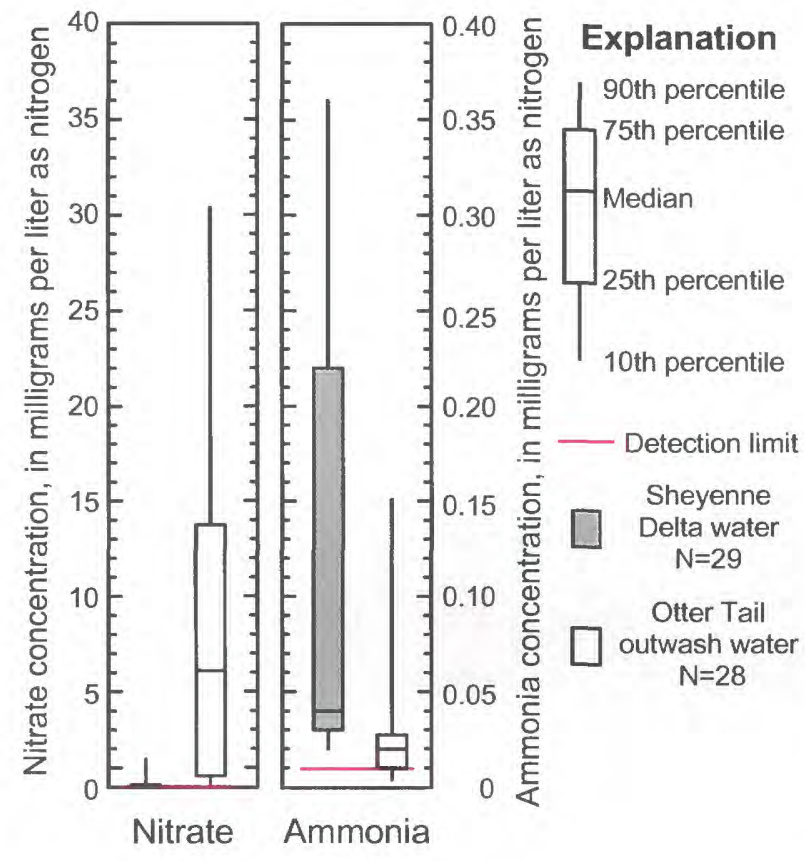

Figure 7-Nitrate and ammonia concentrations in shallow ground water from land-use study areas. [N, number of samples per boxplot]

Total phosphorus and orthophosphorus, each reported as milligrams of phosphorus per liter water (mg/L-P), were the two forms of phosphorus measured in this study. By subtraction, non-orthophosphorus concentrations were calculated and found to be not significantly different (Wilcoxon rank-sum test p-value of 0.66 ) between waters from the study areas, and to be at low concentrations $(0.03 \mathrm{mg} / \mathrm{L}-\mathrm{P}$ maximum, table 8 ). The median concentration of total phosphorus was below the detection limit of $0.01 \mathrm{mg} / \mathrm{L}-\mathrm{P}$ in water from both study areas. Slightly less than $4 \%$ of these waters did contain more than $0.1 \mathrm{mg} / \mathrm{L}-\mathrm{P}$ of orthophosphorus, however. Orthophosphorus is the chemical form that is most readily used by algae. Although no guidelines exist for ground water, Wetzel (1983) reports that the average concentration of phosphorus in lakes with a trophic classification between mesotrophic and eutrophic is about $0.05 \mathrm{mg} / \mathrm{L}-\mathrm{P}$. Nearly $14 \%$ of Otter Tail outwash water and $10 \%$ of Sheyenne Delta water exceeded $0.05 \mathrm{mg} / \mathrm{L}-\mathrm{P}$. Because neither streams nor lakes receive all of their water from ground-water discharge, ground water with phosphorus concentrations higher than $0.05 \mathrm{mg} / \mathrm{L}-\mathrm{P}$ will not necessarily cause eutrophication, but can contribute to it.

\section{Pesticides}

Water from the Sheyenne Delta aquifer had many fewer pesticides, had a lower proportion of water containing pesticides, and had generally lower maximum concentrations of those pesticides detected in both study areas than did water from the Otter Tail outwash aquifer (tables 9 and 10, figure 13). The methods used to analyze pesticide concentrations in the samples for this study have two characteristics that are important to remember when considering the pesticide results presented below. First, although 73 pesticides and 7 pesticide metabolites were quantified in these analyses, only 18 herbicides and 4 insecticides are known to be commonly used on crops grown within the study areas. Second, detection limits and recoveries vary among chemicals (Zaugg and others, 1995; Werner and others, 1996). Some chemicals, particularly those analyzed using the high pressure liquid chromatography method, have consistently low recoveries as noted in the section on quality control detailed in table 15 of the Supplemental Information section. Concentrations of these chemicals are minima. A concentration measured less than the detection limit may not mean that the actual concentration in the water sample is less than that limit (false negatives are possible). On the other hand, a concentration measured above the detection limit means that at least that much of the chemical is in the water sample (false positives are very unlikely).

Five pesticides and one metabolite were detected in Sheyenne Delta water, compared with eight pesticides and two metabolites detected in Otter Tail outwash water (tables 9 and 10). Three of the five pesticides and the metabolite detected in Sheyenne Delta water were also detected in Otter Tail outwash water, totaling 10 different pesticides and 2 metabolites detected in both study areas. All pesticides detected were herbicides, and the parent compounds of both detected metabolites 
Table 8.- Nutrient concentrations in shallow ground water from land-use study areas. [Red values are extrapolated below the detection limit using log-probability regression (Helsel, 1990);

$\mathrm{mg} / \mathrm{L}$, milligrams per liter; $\leq$, less than or equal to]

\begin{tabular}{lcccccc}
\hline \multicolumn{1}{c}{ Nutrient } & $\begin{array}{c}\text { Detection } \\
\text { limit } \\
(\mathrm{mg} / \mathrm{L})\end{array}$ & $\begin{array}{c}\text { Minimum } \\
(\mathrm{mg} / \mathrm{L})\end{array}$ & $\begin{array}{c}10^{\text {th }} \\
\text { percentile } \\
(\mathrm{mg} / \mathrm{L})\end{array}$ & $\begin{array}{c}50^{\text {th }} \\
\text { percentile } \\
(\mathrm{mg} / \mathrm{L})\end{array}$ & $\begin{array}{c}90^{\text {th }} \\
\text { percentile } \\
(\mathrm{mg} / \mathrm{L})\end{array}$ & $\begin{array}{c}\text { Maximum } \\
(\mathrm{mg} / \mathrm{L})\end{array}$ \\
\hline Nitrate as nitrogen & 0.05 & $\leq 0.032^{1}$ & 0.0023 & 0.0328 & 1.46 & 4.3 \\
Nitrite as nitrogen & .01 & $\leq .01$ & $\leq .01$ & $\leq .01$ & .02 & .04 \\
\hline Ammonia as nitrogen & .01 & .01 & .02 & .04 & .36 & .72 \\
Organic nitrogen & .20 & 0 & $\leq .05$ & $\leq .17$ & .37 & .66 \\
\hline Orthophosphorus & .01 & $\leq .01$ & $\leq .01$ & $\leq .01$ & .08 & .12 \\
Non-orthophosphorus & .01 & 0 & 0 & $\leq .01$ & .02 & .03 \\
\hline & 01 & Otter Tail outwash aquifer $(28$ samples $)$ & & \\
\hline Nitrate as nitrogen & .05 & $\leq .05$ & .1418 & 5.6 & 31.8 & 46 \\
Nitrite as nitrogen & .01 & $\leq .01$ & $\leq .01$ & $\leq .01$ & .02 & .09 \\
\hline Ammonia as nitrogen & .01 & $\leq .01$ & .0036 & .02 & .16 & .30 \\
Organic nitrogen & .20 & 0 & $\leq .148$ & $\leq .18$ & .31 & .46 \\
\hline Orthophosphorus & .01 & $\leq .01$ & $\leq .01$ & $\leq .01$ & .09 & .22 \\
Non-orthophosphorus & .01 & 0 & 0 & $\leq .01$ & .02 & .02 \\
\hline
\end{tabular}

${ }^{1}$ less than the detection limit because the value is nitrate plus nitrate $(<0.05)$ from which nitrite $(0.018)$ has been subtracted.

were also detected. Seventeen percent of all shallow ground water in the Sheyenne Delta aquifer contained detectable herbicides compared to $76 \%$ of water in the Otter Tail outwash aquifer. Although the median concentration of the sum of all herbicide mass per liter in samples with herbicides detected was about one-half an order of magnitude higher in Sheyenne Delta water $(0.14 \mu \mathrm{g} / \mathrm{L})$ than in Otter Tail outwash water $(0.043$ $\mu \mathrm{g} / \mathrm{L}$ ), the maximum concentrations for all herbicides found in both study areas, except the herbicide EPTC, were lower in Sheyenne Delta water. Therefore, although a smaller percentage of Sheyenne Delta water contained pesticides, when they were detected, the sum pesticide mass per liter was higher in Sheyenne Delta water. No pesticide in either aquifer was detected at concentrations above health advisory levels.

The most commonly detected herbicides in both study areas were from the triazine family. Atrazine, deethylatrazine (an atrazine metabolite), cyanazine, and simazine accounted for $66 \%$ of total herbicide mass per liter (74\% of detections) measured in both study areas. The bulk of these triazine concentrations $(77 \%)$ were in Otter Tail outwash water. Picloram (56\%) and the triazines (38\%) accounted for nearly all the total pesticide mass per liter measured in Sheyenne Delta water. All of the picloram mass came from one sample, however.

\section{Volatile organic compounds and radioactive elements}

Volatile organic compound and radioactive element concentrations were measured in 1993 in the Sheyenne Delta study area wells. Radioactive elements were measured in only 4 of the 29 Otter Tail outwash study area wells in 1994 and so do not constitute a statistically valid sample for this water. We eliminated volatile organic compound (VOC) analyses from the Otter Tail outwash samples in 1994 because no concentrations attributable to land use were found for these constituents in the Sheyenne Delta study area in 1993. The Sheyenne Delta water concentrations for VOCs and radioactive elements are detailed in table 11 and fig. 9 , respectively. Only two Sheyenne Delta wells produced water containing VOCs. Water from well SD21 contained $0.2 \mu \mathrm{g} / \mathrm{L}$ vinyl chloride, a chemical used in the plastics industry and as a refrigerant. Although the only obvious source for vinyl chloride present near well SD21 is the well casing itself, no vinyl chloride was 

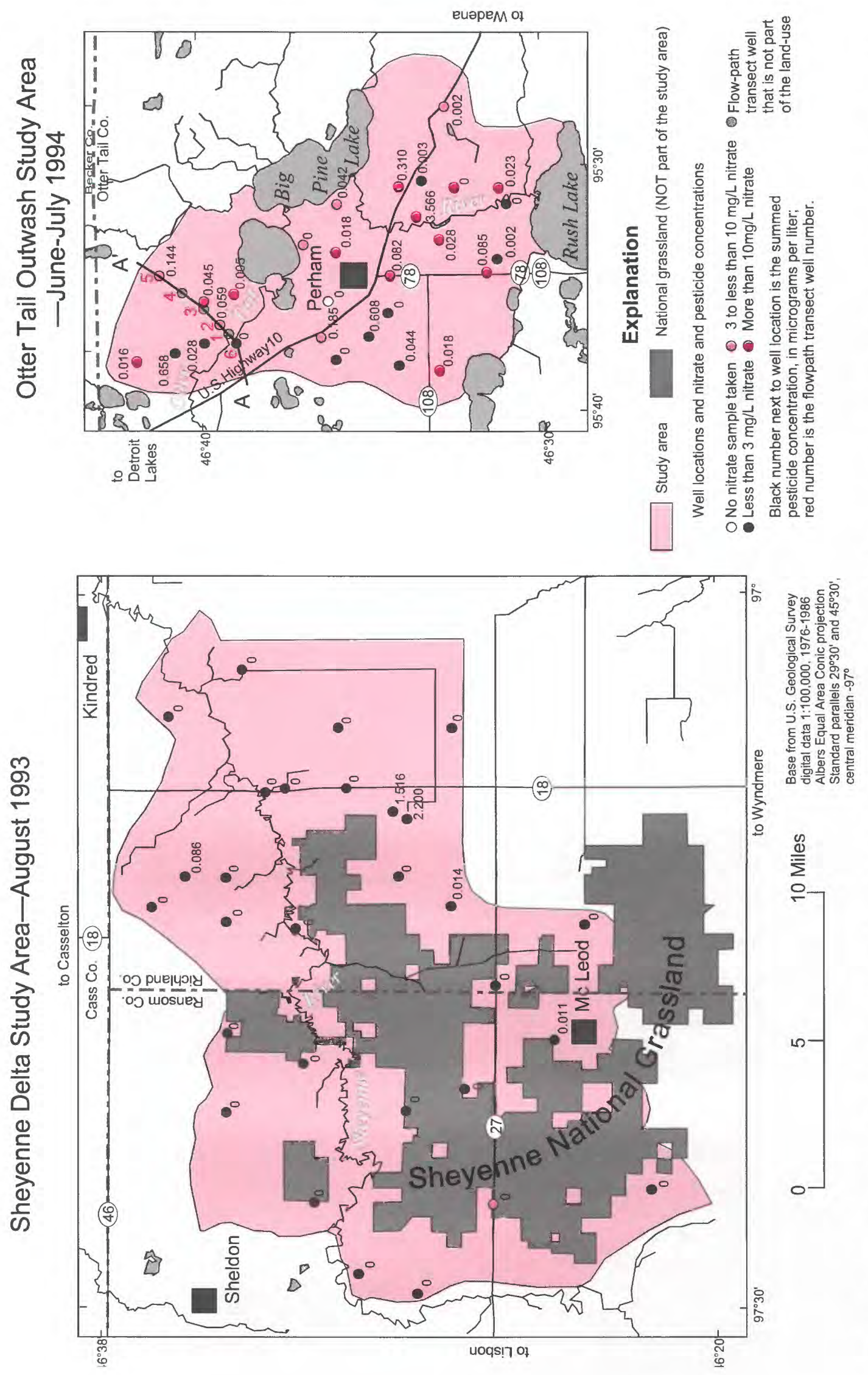

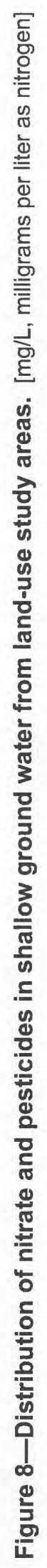


Table 9.-Pesticide (gas chromatography/mass spectrometry analysis) concentrations in shallow ground water from land-use study areas.

$[\mu \mathrm{g} / \mathrm{L}$, micrograms per liter; SD, Sheyenne Delta study area; OTO, Otter Tail outwash study area; MCL, maximum contaminant level; HAL, lifetime adult health advisory level; *, long-term (7 year) adult health advisory level, —, 0 percent; (M), metabolite, 29 samples per study area except acetochlor, which had 10 samples in the OTO and no samples in the SD]

\begin{tabular}{|c|c|c|c|c|c|c|}
\hline Compound & $\begin{array}{l}\text { Detection limit } \\
\quad(\mu \mathrm{g} / \mathrm{L})\end{array}$ & $\begin{array}{l}\text { SD percent } \\
\text { detected }\end{array}$ & $\begin{array}{c}\text { OTO } \\
\text { percent } \\
\text { detected }\end{array}$ & $\begin{array}{l}\text { SD range } \\
(\mu \mathrm{g} / \mathrm{L})\end{array}$ & $\begin{array}{c}\text { OTO range } \\
(\mu \mathrm{g} / \mathrm{L})\end{array}$ & $\begin{array}{l}\text { MCL or HAL } \\
(\mu \mathrm{g} / \mathrm{L})\end{array}$ \\
\hline Acetochlor & 0.002 & & - & & & \\
\hline Alachlor & .002 & - & 3 & & 0.014 & 2 \\
\hline 2,6-diethylaniline (M) & .003 & - & 3 & & .007 & \\
\hline Atrazine & .001 & 7 & 66 & $0.007-1.0$ & $.003-2.4$ & 3 \\
\hline Deethylatrazine (M) & .002 & 7 & 62 & $.004-.51$ & $.002-.64$ & \\
\hline Cyanazine & .004 & - & 7 & & $.013-.019$ & 1 \\
\hline Simazine & .005 & - & 10 & & $.012-058$ & 4 \\
\hline Methyl azinphos & .001 & - & - & & & \\
\hline Benfluralin & .002 & - & - & & & \\
\hline Butylate & .002 & - & - & & & 350 \\
\hline Carbaryl & .003 & - & - & & & 700 \\
\hline Carbofuran & .003 & - & - & & & 40 \\
\hline Chlorpyrifos & .004 & - & - & & & 20 \\
\hline DCPA (dacthal) & .002 & - & - & & & $* 20,000$ \\
\hline$p, p^{\prime}$-DDE (M) & .006 & - & - & & & \\
\hline Diazinon & .002 & - & - & & & .6 \\
\hline Dieldrin & .001 & - & - & & & $* 2$ \\
\hline Disulfoton & .017 & - & - & & & .3 \\
\hline EPTC & .002 & 3 & 7 & .086 & $.004-006$ & \\
\hline Ethalfluralin & .004 & - & - & & & \\
\hline Ethoprop & .003 & - & - & & & \\
\hline Fonofos & .003 & - & - & & & 10 \\
\hline$\alpha$ BHC (M) & .002 & - & - & & & \\
\hline Lindane & .004 & - & - & & & .2 \\
\hline Linuron & .002 & - & - & & & \\
\hline Malathion & .005 & - & - & & & 200 \\
\hline Metolachlor & .002 & 3 & 14 & .006 & $.001-.2$ & 70 \\
\hline Metribuzin (sencor) & .004 & - & 10 & & $.005-.3$ & 100 \\
\hline Molinate & .004 & - & - & & & \\
\hline Napropamide & .003 & - & - & & & \\
\hline Parathion & .004 & - & - & & & \\
\hline Methyl parathion & .006 & - & - & & & 2 \\
\hline Pebulate & .004 & - & - & & & \\
\hline Pendimethalin & .004 & - & - & & & \\
\hline Permethrin, cis & .005 & - & - & & & \\
\hline Phorate & .002 & - & - & & & \\
\hline Prometon & .018 & - & - & & & 100 \\
\hline Pronamide & .003 & - & - & & & 50 \\
\hline Propachlor & .007 & - & - & & & 90 \\
\hline Propanil & .004 & - & - & & & \\
\hline Propargite & .013 & - & - & & & \\
\hline Tebuthiuron & .01 & - & - & & & 500 \\
\hline Terbacil & .007 & - & - & & & 90 \\
\hline Terbufos & .013 & - & - & & & 9 \\
\hline Thiobencarb & .002 & - & - & & & \\
\hline Triallate & .001 & - & - & & & \\
\hline Trifluralin & .002 & - & - & & & 5 \\
\hline
\end{tabular}


Table 10.-Pesticide (high performance liquid chromatography analysis) concentrations in shallow ground water from land-use study areas.

$[\mu \mathrm{g} / \mathrm{L}$, micrograms per liter; SD, Sheyenne Delta study area; OTO, Otter Tail outwash study area; MCL, maximum contaminant level; HAL, lifetime adult health advisory level; *, long-term (7 year) adult health advisory level, compounds in red had low and variable recovery; - 0 percent; (M), metabolite, 29 samples per study area except chlorothalonil in the SD which had 28 samples and propoxur in the OTO which had 27 samples]

\begin{tabular}{|c|c|c|c|c|c|c|}
\hline Compound & $\begin{array}{l}\text { Detection limit } \\
\quad(\mu \mathrm{g} / \mathrm{L})\end{array}$ & $\begin{array}{l}\text { SD percent } \\
\text { detected }\end{array}$ & $\begin{array}{c}\text { OTO } \\
\text { percent } \\
\text { detected }\end{array}$ & $\begin{array}{l}\text { SD range } \\
(\mu \mathrm{g} / \mathrm{L})\end{array}$ & $\begin{array}{l}\text { OTO range } \\
(\mu \mathrm{g} / \mathrm{L})\end{array}$ & $\begin{array}{c}\text { MCL or HAL } \\
\quad(\mu \mathrm{g} / \mathrm{L})\end{array}$ \\
\hline $2,4,5-t$ & 0.035 & - & - & & & 70 \\
\hline $2,4-d$ & .035 & - & - & & & 70 \\
\hline 2,4-db & .035 & - & - & & & \\
\hline Acifluorfen & .035 & - & - & & & $* 400$ \\
\hline Aldicarb & .016 & - & - & & & 7 \\
\hline Aldicarb sulfone (M) & .016 & - & - & & & 7 \\
\hline Aldicarb sulfoxide (M) & .021 & - & - & & & 7 \\
\hline Bentazon & .014 & - & 3 & & 0.4 & 20 \\
\hline Bromacil & .035 & - & - & & & 80 \\
\hline Bromoxynil & .035 & 一 & - & & & \\
\hline Carbaryl & .008 & - & - & & & 700 \\
\hline Carbofuran & .028 & - & - & & & 40 \\
\hline 3-hydroxycarbofuran & .014 & - & - & & & \\
\hline Chloramben & .011 & - & - & & & 100 \\
\hline Chlorothalonil & .035 & - & - & & & $* 500$ \\
\hline Clopyralid & .05 & - & - & & & \\
\hline Cresol, 4,6-dinitro-o & .035 & - & - & & & \\
\hline DCPA (dacthal) & .017 & - & - & & & $* 20,000$ \\
\hline Dicamba & .035 & 3 & - & 0.14 & & 200 \\
\hline Dichlobenil & .02 & - & - & & & \\
\hline Dichlorprop & .032 & - & - & & & \\
\hline Dinoseb & .035 & - & - & & & 7 \\
\hline Diuron & .02 & - & - & & & 10 \\
\hline Esfenvalerate & .019 & - & - & & & \\
\hline Fenuron & .013 & - & - & & & \\
\hline Fluometuron & .035 & - & - & & & \\
\hline Linuron & .018 & - & - & & & \\
\hline MCPA & .05 & - & - & & & 10 \\
\hline MCPB & .035 & - & - & & & \\
\hline Methiocarb & .026 & - & - & & & \\
\hline Methomyl & .017 & - & - & & & 200 \\
\hline 1-naphthol (M) & .007 & - & - & & & \\
\hline Neburon & .015 & - & - & & & \\
\hline Norflurazon & .024 & - & - & & & \\
\hline Oryzalin & .019 & - & - & & & \\
\hline Oxamyl & .018 & - & - & & & 200 \\
\hline Picloram & .05 & 3 & - & 2.2 & & 500 \\
\hline Propham & .035 & - & - & & & 100 \\
\hline Propoxur & .035 & - & - & & & \\
\hline Silvex & .021 & - & - & & & \\
\hline Triclopyr & .05 & - & - & & & \\
\hline
\end{tabular}


detected in any other samples. The concentration is at the detection limit and may be from a small local spill or sample contamination from the well casing, sampling equipment, and/or during laboratory analysis. All quality-control blank samples collected were free of vinyl chloride.

All other VOCs measured were in water from well SD25. This water contained 10 VOCs, 9 of which are members of the benzene-toluene-xylene family of compounds. These compounds are often grouped together because they are components of petroleum that readily dissolve in water. The tenth compound is naphthalene, a less soluble component of petroleum. Well SD25 was drilled in 1972 and has served as a monitoring well on a field access road from a welltraveled state highway. Because the well is located in a relatively well-traveled area, its water contains so many components of petroleum, and essentially no other water in the study area contained any detectable VOCs, 1 suspect that this location may have been contaminated by petroleum, perhaps gasoline or motor oil, at some time in its 21-year existence. VOCs detected in Sheyenne Delta water were at least one order of magnitude below the USEPA drinking water maximum contaminant level (MCL) for the five compounds for which a level is established.

All known sources of the radioactive elements uranium, radium, and radon in the Sheyenne Delta study area are natural, associated with uranium found in the sediments composing the aquifer or ground water leaking upward from deeper aquifers. Uranium concentrations in water samples were all less than the USEPA drinking water MCL of $20 \mu \mathrm{g} / \mathrm{L}$ (fig. 9) with the exception of water from well SD26. The uranium concentration range does exceed the MCL, however. Well SD26 produced water with $71 \mu \mathrm{g} / \mathrm{L}$ of uranium. Water from this well has unusually high concentrations of some other constituents as well, particularly sulfate $(1,800 \mathrm{mg} / \mathrm{L})$ and dissolved oxygen $(3.95 \mathrm{mg} / \mathrm{L})$, and is very unlike any other water sampled in this study. Uranium is most soluble in its oxidized form. It is likely that this water was affected by another source of water with a high uranium concentration or flowed through unoxidized sediments containing uranium, dissolving it and forming uranyl ions (Wanty and Nordstrom, 1993). Radium concentrations in Sheyenne Delta ground water were low, an order of magnitude below the USEPA drinking water $\mathrm{MCL}$ of 5 picocuries per liter $(\mathrm{pCi} / \mathrm{L})$. The low concentrations of radium measured in Sheyenne Delta water is reasonable because radium is strongly adsorbed to minerals including those common in the Sheyenne Delta aquifer — quartz and clay minerals (Wanty and Nordstrom, 1993).
Radon concentrations in more than $70 \%$ of Sheyenne Delta water were above the USEPA drinking water MCL of $300 \mathrm{pCi} / \mathrm{L}$. This standard is currently under review (U.S. Environmental Protection Agency, 1996). These concentrations are not unusual for ground waters, however. Wanty and Nordstrom (1993) note that concentrations of radon in ground water are usually in the range of hundreds or thousands of $\mathrm{pCi} / \mathrm{L}$, due to its nonreactivity as a noble gas.

\section{Vertical and seasonal variability}

The study design for both land-use areas focused on the ground water at the water table because this water is most susceptible to changes from land uses. These changes in water quality were much greater in Otter Tail outwash water than in Sheyenne Delta water. But the water at the water table makes up only a small part of the total ground water in these surficial aquifers. Based on water-well records, water is usually drawn from the deeper parts of the aquifer. Therefore, the water sampled in these land-use studies is not necessarily representative of the ground water that is used or consumed. Further, water sampled in these land-use studies was collected within a period of about one month during the summer in two different years. The water collected during these short periods may not represent water throughout the year and may not be comparable between years. The distribution of water quality, vertically and seasonally, provides insights into the fate of agricultural chemicals in the aquifer. Data from the flow-path transect wells nested within each land-use study and from the land-use wells sampled seasonally places the land-use water-quality data into the context of the water quality throughout the entire aquifer and through time.

Flow-path transect samples from both study areas demonstrate that nitrate concentrations were stratified vertically within the aquifers. Because nitrate was the agricultural chemical that most changes ground-water quality in these aquifers and because its concentration is relatively inexpensive to determine, we used nitrate to assess the vertical and seasonal distribution of land-use effects on water quality. The entire flow-path transect was sampled once in the Sheyenne Delta study area and three times in the Otter Tail outwash study area. The three sets of nitrate concentrations from the transect in the Otter Tail outwash study area (fig. 10) show the vertical stratification. Nitrate concentrations were very low (generally less than $0.05 \mathrm{mg} / \mathrm{L}$ ) for all wells that are set well below the water table. An exception was at well nest 1 (fig. 10) where concentrations decreased with depth gradually, based on samples collected during 
Table 11.-Volatile organic compounds in shallow ground water from the Sheyenne Delta study area. $[\mu \mathrm{g} / \mathrm{L}$, micrograms per liter; MCL. maximum contaminant level; HAL, lifetime adult health advisory level,

-, less than detection limit, 28 samples]

\begin{tabular}{|c|c|c|c|c|}
\hline Compound & $\begin{array}{c}\text { Detection } \\
\text { limit } \\
{[\mu \mathrm{g} / \mathrm{L}]}\end{array}$ & $\begin{array}{c}\text { Detected } \\
\text { concentration } \\
(\mu \mathrm{g} / \mathrm{L})\end{array}$ & $\begin{array}{c}\text { MCL or HAL } \\
{[\mu \mathrm{g} / \mathrm{L}]}\end{array}$ & $\begin{array}{c}\text { Well } \\
\text { number }\end{array}$ \\
\hline Methylchloride & 0.2 & - & 3 & \\
\hline Methylbromide & .2 & - & 10 & \\
\hline Methylenechloride & .2 & - & 5 & \\
\hline Methane, bromochloro- & .2 & - & 10 & \\
\hline Methane, dibromo- & .2 & - & & \\
\hline Chloroform & .2 & - & 100 & \\
\hline Bromoform & .2 & - & 100 & \\
\hline Methane, dichlorobromo- & .2 & - & & \\
\hline Methane, dichlorodifluoro- & .2 & - & 1,000 & \\
\hline Methane, chlorodibromo- & .2 & - & 100 & \\
\hline Carbontetrachloride & .2 & - & 5 & \\
\hline Methane, trichlorofluoro- & .2 & - & & \\
\hline Ethane, chloro- & .2 & - & & \\
\hline Ethane, 1,1-dichloro- & .2 & - & & \\
\hline Ethane, 1,2-dichloro- & .2 & - & & \\
\hline Ethane, 1,2-dibromo- & .2 & - & & \\
\hline Ethane, 1,1,1-trichloro- & .2 & - & 200 & \\
\hline Ethane, 1,1,2-trichloro- & .2 & - & 5 & \\
\hline Ethane, 1,1,1,2-tetrachloro- & .2 & - & 70 & \\
\hline Ethane, 1,1,2,2-tetrachloro- & .2 & - & & \\
\hline Vinyl chloride & .2 & 0.2 & 2 & SD21 \\
\hline Ethene, 1,1-dichloro- & .2 & - & 7 & \\
\hline Ethene, cis-1,2-dichloro- & .2 & - & 70 & \\
\hline Ethene, trans-1,2-dichloro- & .2 & - & 100 & \\
\hline Ethene, trichloro- & .2 & - & 5 & \\
\hline Ethene, tetrachloro- & .2 & - & 5 & \\
\hline Propane, 1,2-dichloro- & .2 & - & 5 & \\
\hline Propane, 1,3-dichloro- & .2 & - & & \\
\hline Propane, 2,2-dichloro- & .2 & - & & \\
\hline Propane, 1,2,3-trichloro- & .2 & - & 40 & \\
\hline Propane, dibromochloro- & .2 & - & 0.2 & \\
\hline Propene, 1,1-dichloro- & .2 & - & & \\
\hline Propene, cis-1,3-dichloro- & .2 & - & & \\
\hline Propene, trans-1,3-dichloro- & .2 & - & & \\
\hline Benzene & .2 & - & 5 & \\
\hline Benzene, chloro & .2 & - & & \\
\hline Benzene, $o$-chloro- & .2 & - & & \\
\hline Benzene, bromo- & .2 & - & & \\
\hline Benzene, 1,3-dichloro- & .2 & - & 600 & \\
\hline Benzene, 1,4-dichloro- & .2 & - & 75 & \\
\hline Benzene, 1,2,4-trichloro- & .2 & - & 70 & \\
\hline Benzene, 1,2,3-trichloro- & .2 & - & & \\
\hline Benzene, 1,2,4-trimethyl- & .2 & 10 & & SD25 \\
\hline Benzene, 1,3,5-trimethyl- & .2 & 2.9 & & SD25 \\
\hline
\end{tabular}


Table 11.- Volatile organic compounds in shallow ground water from the Sheyenne Delta study area—continued.

\begin{tabular}{|c|c|c|c|c|}
\hline Compound & $\begin{array}{c}\text { Detection } \\
\operatorname{limit} \\
{[\mu \mathrm{g} / \mathrm{L}]}\end{array}$ & $\begin{array}{c}\text { Detected } \\
\text { concentration } \\
(\mu \mathrm{g} / \mathrm{L})\end{array}$ & $\begin{array}{c}\text { MCL or HAL } \\
{[\mu \mathrm{g} / \mathrm{L}]}\end{array}$ & $\begin{array}{l}\text { Well } \\
\text { number }\end{array}$ \\
\hline Benzene, ethyl- & 0.2 & 7.4 & 700 & SD25 \\
\hline Benzene, $n$-butyl- & .2 & .3 & & SD25 \\
\hline Benzene, sec-butyl- & .2 & - & & \\
\hline Benzene, tert-butyl- & .2 & - & & \\
\hline Benzene, $n$-propyl- & .2 & 1.9 & & SD25 \\
\hline Benzene, isopropyl- & .2 & .5 & & SD25 \\
\hline Toluene & .2 & 4.8 & 1.000 & SD25 \\
\hline Toluene, o-chloro- & .2 & - & 100 & \\
\hline Toluene, $p$-chloro- & .2 & - & 100 & \\
\hline Toluene, $p$-isopropyl- & .2 & - & & \\
\hline Xylene & .2 & 36 & 10.000 & $\mathrm{SD} 25$ \\
\hline Styrene & .2 & .3 & 100 & SD25 \\
\hline Naphthalene & .2 & .4 & 20 & $\mathrm{SD} 25$ \\
\hline Freon 113 & .2 & - & & \\
\hline Hexachlorobutadiene & .2 & - & 50 & \\
\hline Ether, methyl tert-butyl- & .2 & - & $20-200$ & \\
\hline
\end{tabular}

August 1995. Nitrate concentrations showed a similar vertical distribution at the Sheyenne Delta flow-path transect.

This vertical nitrate concentration distribution is consistent with the land-use history of the Otter Tail outwash study area. Along the flow-path transect, land use is mostly irrigated row-crop production with some wetlands interspersed (particularly around well 4 (well number OF4S)) and woods near the flow-path transect end at well nest 1 . Agricultural nitrogen application rates in the study area increased about 5 -fold between 1965 and 1995 and irrigated acreage increased 3-fold between 1980 and 1995 (Cowdery and others, 1995). This land use resulted in a fairly areally uniform, but increasing nitrate source at the land surface during the last three decades. Assuming this nitrate input history, fairly constant recharge to the aquifer spatially and seasonally, and no nitrate degradation along flow, nitrate concentrations in the ground water would be expected to be highest at the water table where the water is youngest and decrease with depth, at least to where the water is about 30 years old. The rate of this age increase and nitrate decrease with depth would be expected to be high in most of the aquifer where the vertical head gradient is small, there is little vertical flow, and recharging water mostly "stacks up" and flows horizontally. Near the Otter Tail River (well nest 1) where the water table slope increases, the vertical head gradient also increases, driving water deeper into the aquifer (Freeze and Witherspoon, 1967), thereby decreasing the age gradient and causing a lower rate of nitrate and DO decrease with depth. If denitrification occurs in the aquifer, a similar vertical nitrate pattern would exist, except that the rate of nitrate decrease with depth would be generally higher across the aquifer because denitrification would decrease nitrate concentration with age and therefore depth.

This basic scenario was confirmed by determining the post-recharge age of the water (resolution less than 2 years) at each well during August 1995, based on chlorofluorocarbon (CFC) concentration (Busenburg and Plummer, 1992). The youngest water (highest nitrate input) was at the water table; the oldest (lowest nitrate input) was at the bottom of the aquifer (Cowdery and others, 1995) (fig. 11). The vertical age gradient was higher at well nest 3 (well numbers OF3S, M, D in order of increasing depth) than it was at well nest 1 , near the discharge area. Although the vertical resolution from sampling points in the flow-path transect is poor, results from these wells show that both the age gradient and the rate of nitrate and DO decrease with depth decreased from well nest 3 to well nest 1 , as expected. Vertical head-gradients were near zero or slightly upward at well nest 3 , but changed to downward at well nest 2 and the unconfined part of well nest 1. Clay or till layers complicate flow within the aquifer, but the 
vertical age, nitrate, $\mathrm{DO}$, and head gradients are consistent with the simplistic flow scenario in the preceeding paragraph. Nitrate-affected water was near the water table, but extended deeper into the saturated zone near the discharge area. Boehlke and others (1994) found a similar pattern of nitrate concentration and ground-water age in a sand-plain aquifer in central Minnesota. All water with a recharge date before the middle 1960's had a nitrate concentration less than 0.05 $\mathrm{mg} / \mathrm{L}$. Excess nitrogen gas in most flow-path transect samples (Cowdery and others, 1995) indicated that denitrification does occur in the aquifer. The amount of denitrification is unknown, however. A similar vertical nitrate-concentration distribution was also present in samples from flow-path transect wells in the Sheyenne Delta study area. The distributions of nitrate along the flow-path transects suggest that, in general, concentrations of agricultural chemicals measured in the land-use studies are maxima because they were collected near the water table, and reflect the greatest influence on ground-water quality from the agricultural land use over these aquifers.

Sampling for the land-use studies was conducted within about one month's time during August 1993 and June-July 1994. Because any given time period is unlikely to be normal (the unusually high rainfall during the Sheyenne Delta study area sampling was very abnormal), repeat sampling of selected land-use and flow-path transect wells can place the chemical concentrations measured in the land-use studies into the context of normal seasonal variability. As with vertical spatial variability of water quality within the aquifer, nitrate concentrations served as a good example of seasonal chemical variability. Pesticide concentrations were also measured at different times in these selected wells. The purpose of these analyses was to assess seasonal variability, not to detect any trend in water quality, of which they are statistically incapable.

Both nitrate and pesticide concentrations measured in land-use and flow-path transect wells during November 1993 through September 1995 demonstrate that although seasonal variability does exist, it is usually less than one-half of an order of magnitude (figs. 12 and 13). Furthermore, no consistent seasonal influence is apparent in nitrate concentration through time at all wells (fig. 12). Water from some wells, such as OT17 and most of the Sheyenne Delta study area wells, contained fairly low concentrations of nitrate which changed little seasonally. Water from some wells (wells OT28, SF1S, and SF3S) had fairly constant concentrations (some high, some low) with an

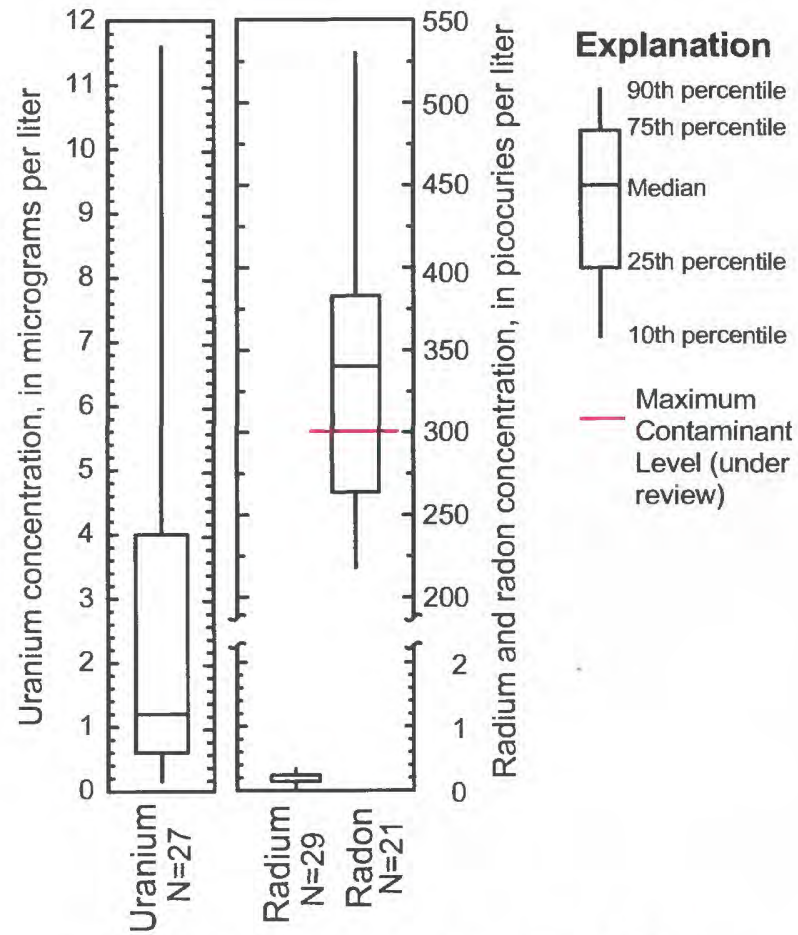

Figure 9-Uranium, radium, and radon concentrations in shallow ground water from the Sheyenne Delta study area. [N, number of samples per boxplot]

occasional spike or dip. Still other waters (from wells OF1S and OF3S, particularly) fiuctuate around a median concentration. Nitrate concentrations in water from these wells, and perhaps from wells OT09 and SF3S as well, appear to respond seasonally. Water from well OF3S shows the pattern most distinctly. Nitrate concentrations begin relatively low in April 1994, diluted by spring recharge from snowmelt. As fertilizer is applied to fields in the spring, recharge from rain carries nitrate to the water table, increasing concentrations. These concentrations remain fairly high until the next spring when concentrations are again diluted by recharge from snowmelt. The most notable feature of these plots, however, is the consistently much lower nitrate concentrations in ground water from the Sheyenne Delta aquifer than in ground water from the Otter Tail outwash aquifer. Wells SF1S and SF3S contain the highest concentrations of nitrate measured in the Sheyenne Delta aquifer during this study. Both of these wells were excluded from the land-use sampling network because they are located along a flow path containing a confined winter cattle-feeding area. It is possible that this land use, which exists over a very small portion of the Sheyenne Delta study area, is a source of the high nitrate concentrations in the ground 


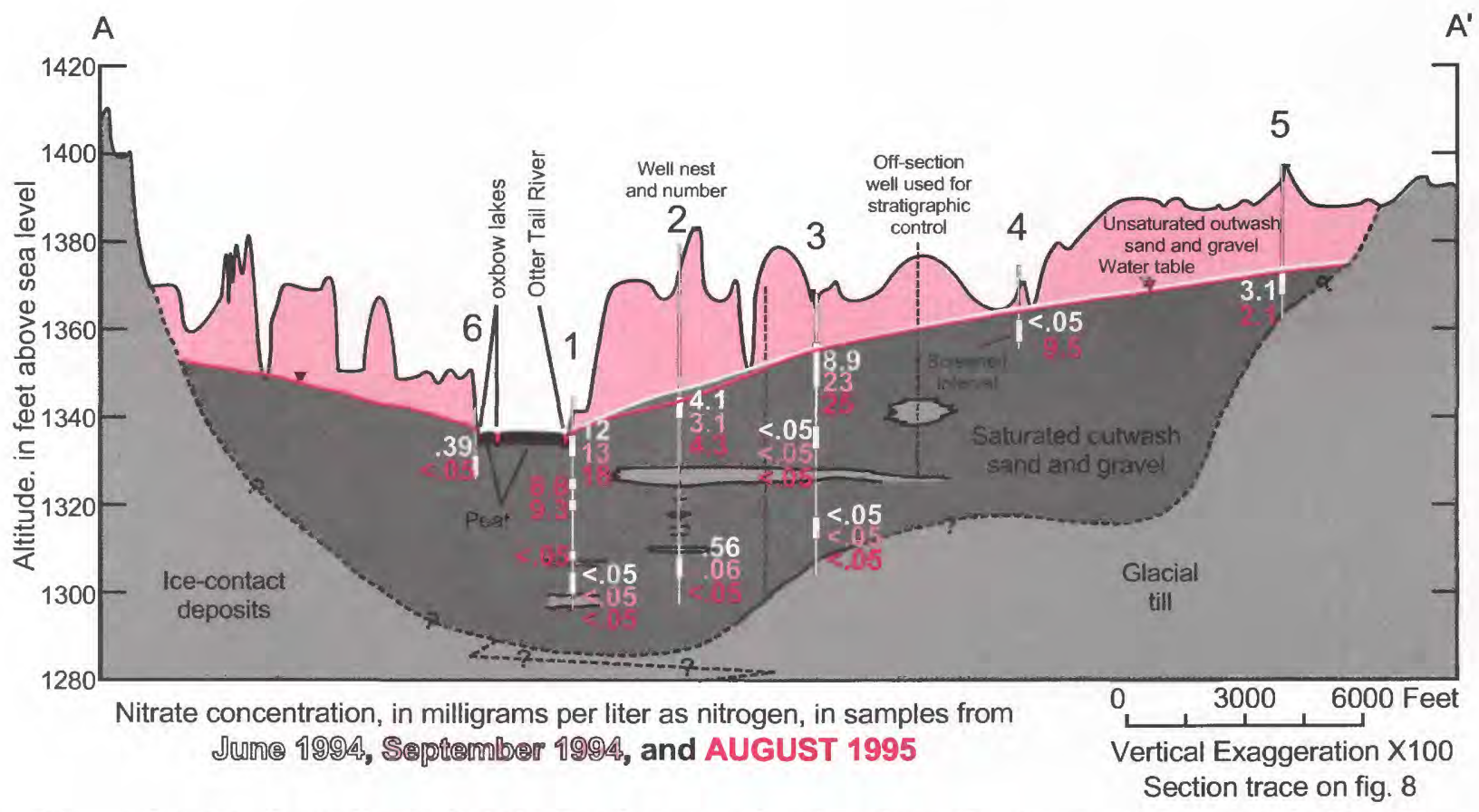

Figure 10-Vertical nitrate distribution in ground water along the flow-path transect in the Otter Tail outwash study area.

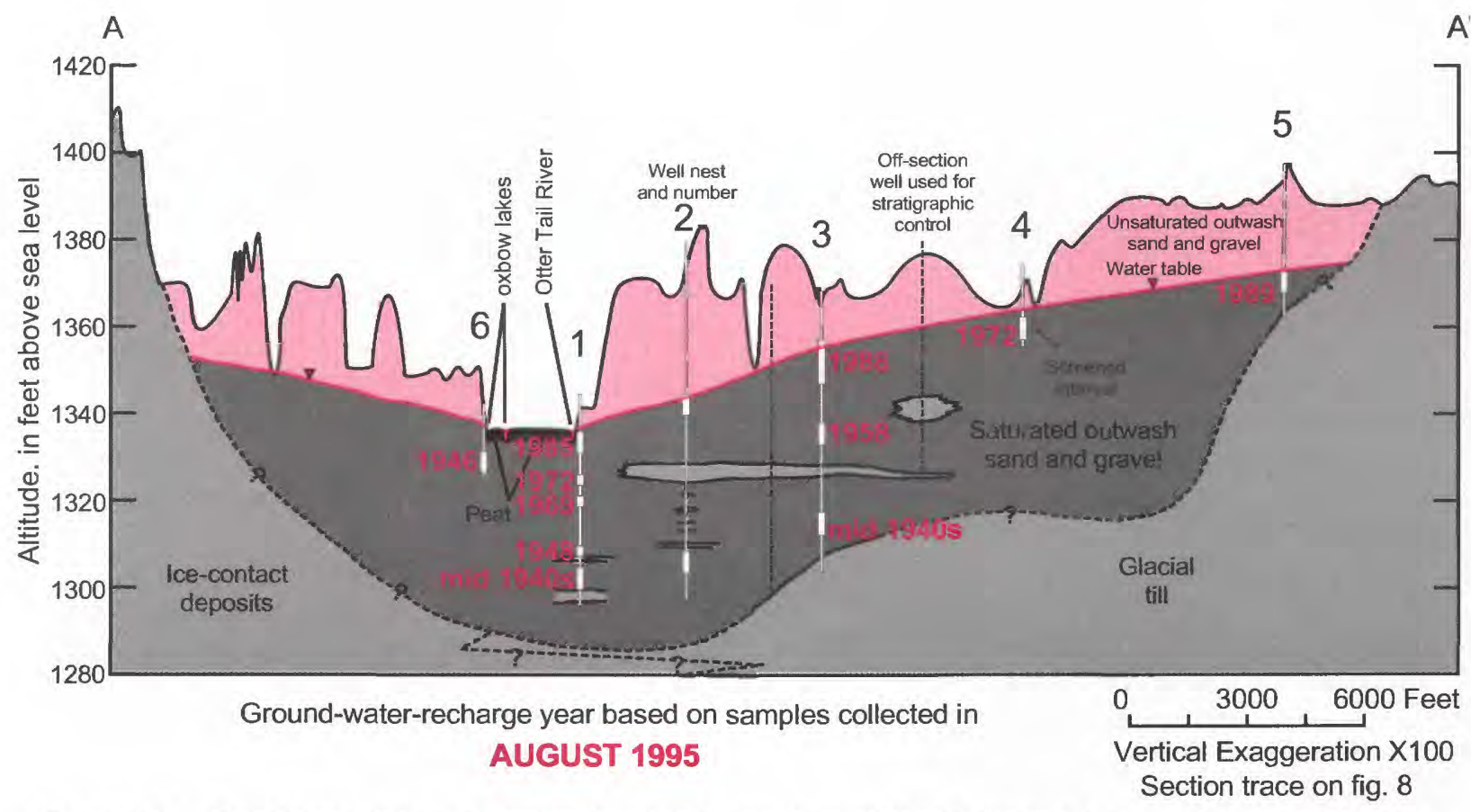

Figure 11-Recharge dates of ground water, based on chloroflourocarbon analyses, along the flow-path transect in the Otter Tail outwash study area. 

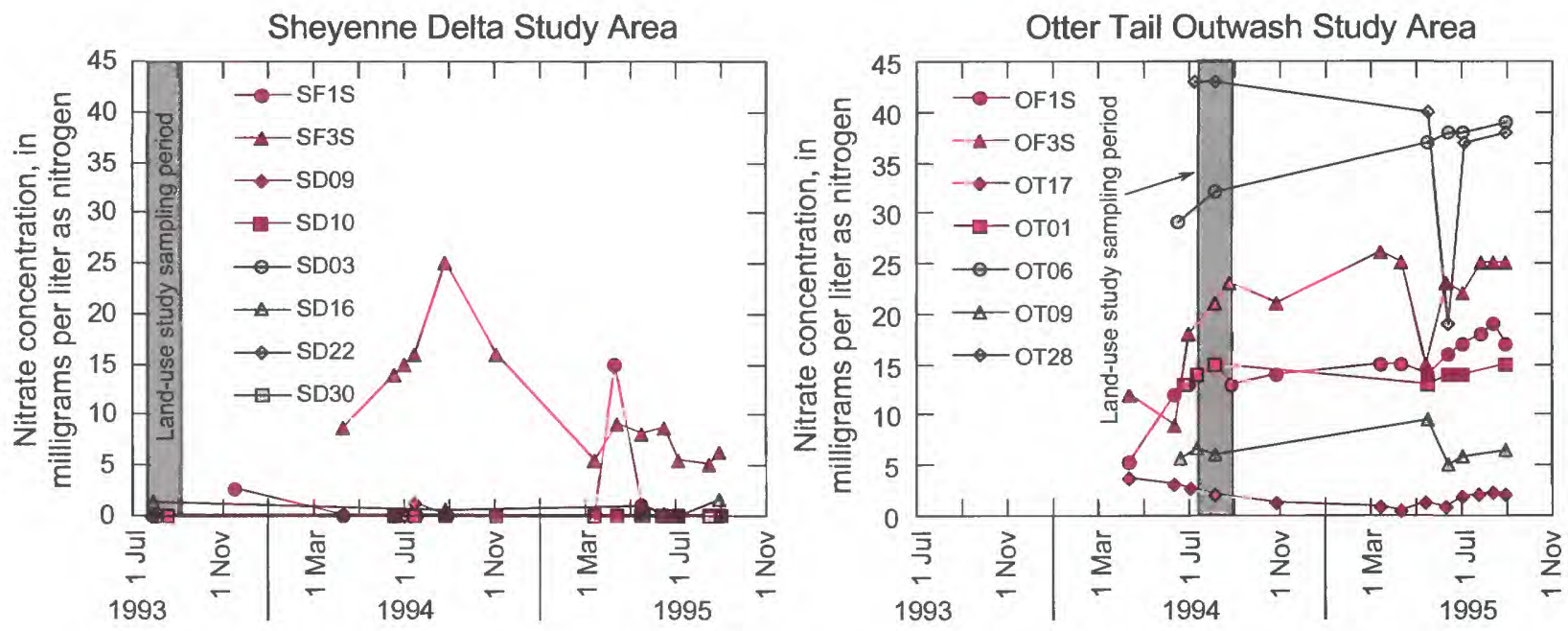

Figure 12-Seasonal nitrate variability in shallow ground water from the land-use study areas.

water. The changing nitrate concentrations depicted in figure 12 demonstrate how difficult it is to identify and separate the various land-use, hydrogeological, and climatic factors responsible for the ground-water quality in a certain place at a certain time. However, because all 29 samples from each land-use study are taken as an aggregate assessment of the general shallow groundwater quality in each aquifer, individual departures from the median concentration at a well are averaged out, yielding an accurate picture of the water quality as a whole.

In addition to samples collected for the land-use studies, a total of 22 pesticide samples ( 20 samples of HPLC pesticides) were collected from 9 Sheyenne Delta land-use and flow-path transect wells and 16 samples from 13 Otter Tail outwash land-use and flow-path transect wells during 1993 through 1995. All pesticide detections from these samples are aggregated in figure 13 and presented with a plot similar to the 29 pesticide samples from each land-use study. With the exception of $p, p^{\prime}$-DDE, a metabolite of the insecticide DDT banned in the early 1970 's, all pesticides detected in the seasonal samples were also detected in the land-use samples. Several pesticides (cyanazine, 2,6-

dethylanaline, and bentazon) detected rarely and at fairly low concentrations in samples from the land-use studies were not detected in the seasonal samples. The fewer number of pesticides detected in the seasonal samples probably resulted from the fewer number of wells sampled. The general distribution of detections and concentrations was quite similar between the landuse pesticide data and the seasonal-pesticide data. Triazine herbicides dominated detections in both data sets at similar concentrations. The number of herbicide detections was much higher in ground water from the Otter Tail outwash aquifer than from the Sheyenne Delta aquifer. In fact, picloram, widely used only in the Sheyenne Delta study area, was the only pesticide detected in seasonal samples from the Sheyenne Delta aquifer. Picloram was detected in some wells more than once but not every time a well was sampled. This comparison suggests that the percentage of ground water in each study area affected by agricultural pesticides was not influenced by the particular time at which the land-use samples were collected, but rather forms a representative assessment of the water quality in each aquifer.

\section{Factors Influencing Water Quality}

In general, several constituents in the shallow ground water from the Sheyenne Delta aquifer distinguish it from shallow ground water in the Otter Tail outwash aquifer. These constituents are not the ions which make up the bulk of the dissolved solids in these waters (fig. 6). Rather, they are some of the nutrients and herbicides that are applied to the land surface, mostly for agricultural production. Differences in land use between the two study areas can only partially explain these differences in ground-water quality. Differences in the hydrogeology of the aquifers and precipitation between the two study areas also contribute to the waterquality differences.

\section{Land use}

Chemicals applied to agricultural land are the principal source for nitrates at concentrations above about $3 \mathrm{mg} / \mathrm{L}$ and for all pesticides found in the shallow 

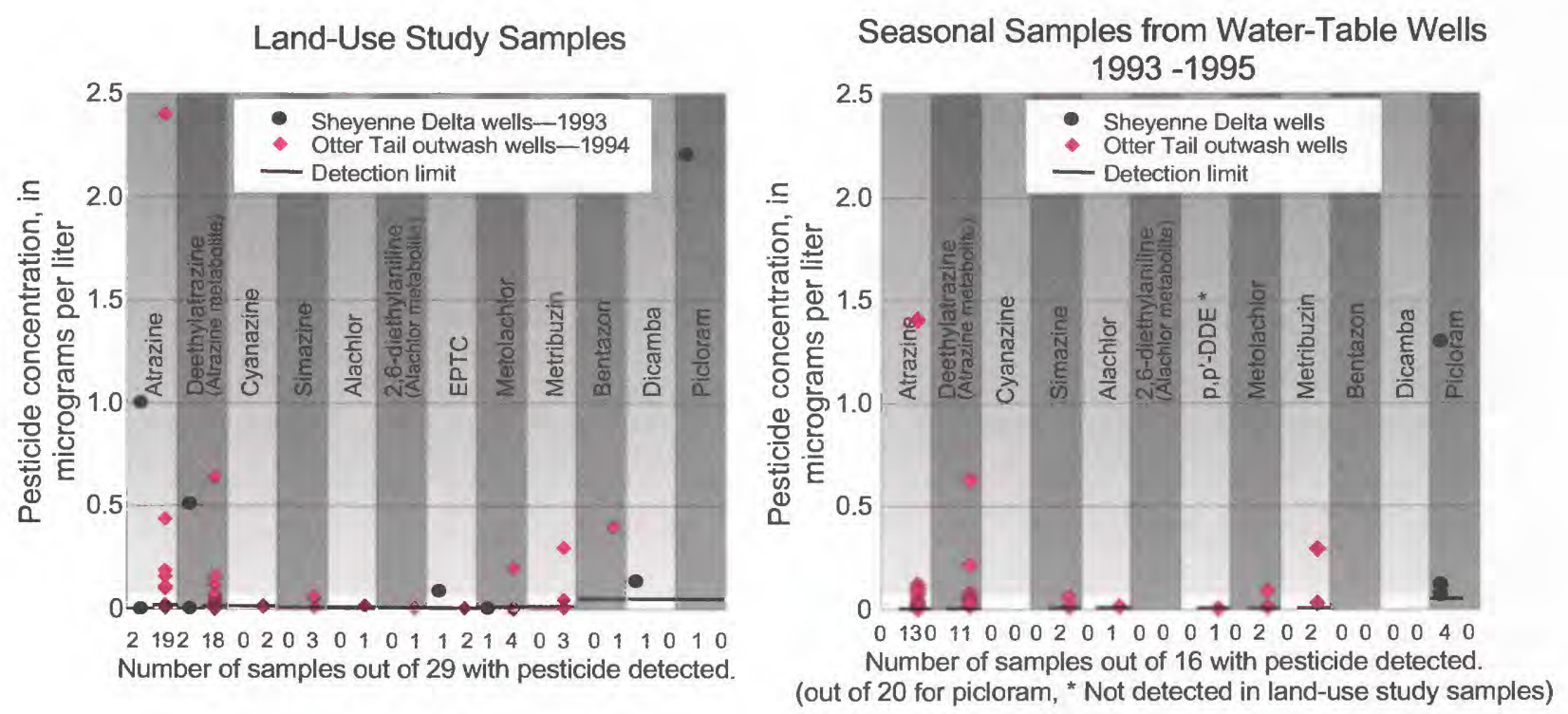

Figure 13-Pesticide concentrations in shallow ground water from land-use study areas.

ground water in these study areas. Profound differences in shallow ground-water quality result from appreciable differences in the amount of cropland, the contiguity of crop land relative to other land uses, the crops grown, and the proportion of crops irrigated. The relation of these land-use characteristics to increased agricultural effects on shallow ground water is simple in many cases. Crops that are grown using more chemicals, or chemicals that degrade more slowly in the soil, provide a larger source of chemicals that can move to the ground water. Land that is irrigated can provide more percolating water with which to carry agricultural chemicals to the water table because the field capacity of the soil is more often and more quickly exceeded. The land use in the Otter Tail outwash study area caused larger concentrations of agricultural chemicals in the shallow ground water than did the land use in the Sheyenne Delta study area.

Although agricultural chemicals are used in all landuse categories listed in table 4 , cropland and haying (mostly cropland; hereinafter, cropland) received the largest chemical application. This land use was the largest in both study areas, but accounted for $9 \%$ more of land use in the Otter Tail outwash study area (table 4). The greater proportion of cropland in the Otter Tail outwash study area decreased the proportion of grassland and pasture (mostly used for grazing; hereinafter, grazing). Corn was the main crop grown in both study areas (about one third of the cropland in each area) (table 5). Corn consumes relatively high quantities of nitrogen and is often treated with triazine herbicides. The importance of this crop is reflected in the high-use position of cyanazine, alachlor, and atrazine in table 7. Although corn was grown on a slightly smaller proportion of cropland in the Otter Tail study area, both nitrogen and triazine herbicide application rates were much higher than those for the Sheyenne Delta study area. It is therefore likely that these greater application rates contribute to the greater concentrations of nitrate and triazine herbicides in Otter Tail outwash shallow ground water. This effect is accentuated by the moderate persistence in soils (Winkelmann and Klaine, 1991) of the triazine herbicide atrazine. Atrazine was, therefore, more available for leaching to the ground water. The larger area used for grazing in the Sheyenne Delta study area is likely responsible for the picloram (an herbicide used to control leafy spurge in grasslands) found in the shallow ground water there. Because nutrients and many herbicides were used on many crops, chemical concentrations in shallow ground water cannot be attributed to various land uses precisely. Aggregated, however, the differences between the study areas in land use and crops grown resulted in more than twice as much nutrient and $22 \%$ more pesticide mass applied to the Otter Tail outwash study area. This substantially higher agricultural-chemical use contributed to the higher concentrations in the shallow ground water of this area.

Large differences in irrigation also contributed to the poorer shallow ground-water quality of the Otter Tail outwash study area. In 1991, nearly 7 times as much crop area was irrigated in the Otter Tail outwash study area as in the Sheyenne Delta study area. Further, the 
percentage of cropland that came under irrigation between 1984 and 1991 was 4 times larger in the Otter Tail outwash study area (table 5). Operators generally try to irrigate so that no irrigation water percolates to the water table. However, percolation can occur, particularly when unexpected rainfall occurs during or just after irrigation. Percolation can carry agricultural chemicals to the ground water. Because the Otter Tail outwash study area had nearly 7 times more acreage under irrigation, such percolation was more likely to occur. This difference in irrigation contributed to the 100-times-higher median nitrate concentration and $60 \%$-higher median total-measured-pesticide concentration in Otter Tail outwash shallow ground water.

The interspersed national grassland in the Sheyenne Delta study area (fig. 2) is another land-use characteristic which may have resulted in lower agricultural-chemical concentrations in this study area. The national grassland is primarily used for grazing and, in recent years, pesticide use was forbidden within its boundaries. In effect, large, interspersed areas of grassland decreases the contiguity of cropland and decreases the overall land-use effect of chemicalintensive agriculture in the Sheyenne Delta study area. This decrease contributes to lower agricultural chemical concentrations in ground water compared to that in the Otter Tail outwash study area. Because vertical groundwater head gradients are downward in most of the aquifer, the effect of interspersed national grasslands on water quality would be very small in the shallow ground water, but may be important in the deeper parts of the aquifer.

\section{Hydrogeology}

Ideally, the two study areas chosen to investigate land-use effects on ground-water quality would differ only in land use. There are important differences in hydrogeology between the study areas, however, which likely have an influence on shallow ground-water quality. The characteristics of the Sheyenne Delta study area promote processes that remove agricultural chemicals from the soil before they can enter the ground water or remove the chemicals from percolating water or from ground water itself.

The finer and less homogeneous aquifer texture, and the shallower depth to ground water (fig. 14) in the Sheyenne Delta study area, contribute to keeping both percolating recharge water and shallow ground water in contact with the soil zone. Finer aquifer material, having lower hydraulic conductivity, inhibits initial infiltration, percolation, and ground-water movement.
The fining-upward depositional sequences (vertically alternating low and high hydraulic conductivity) composing the underflow fan deposits of the Sheyenne Delta, further reduce the vertical hydraulic conductivity of this aquifer. These characteristics provide percolating water with a slower traverse through the soil zone in the Sheyenne Delta study area. While in the soil zone, dissolved oxygen in percolating water is first used by bacteria as an oxidizer, consuming soil organic matter for energy. Once dissolved oxygen is exhausted, bacteria will use any nitrate present in the water as an oxidizer converting the nitrate to reduced forms of nitrogen including ammonia. The characteristics of the Sheyenne Delta aquifer that allow the percolating water and shallow ground water to remain in the soil zone also help explain why herbicide concentrations are lower than they are in Otter Tail outwash water. Herbicides are likely to undergo biodegradation in the soil zone where bacteria are actively decomposing organic matter.

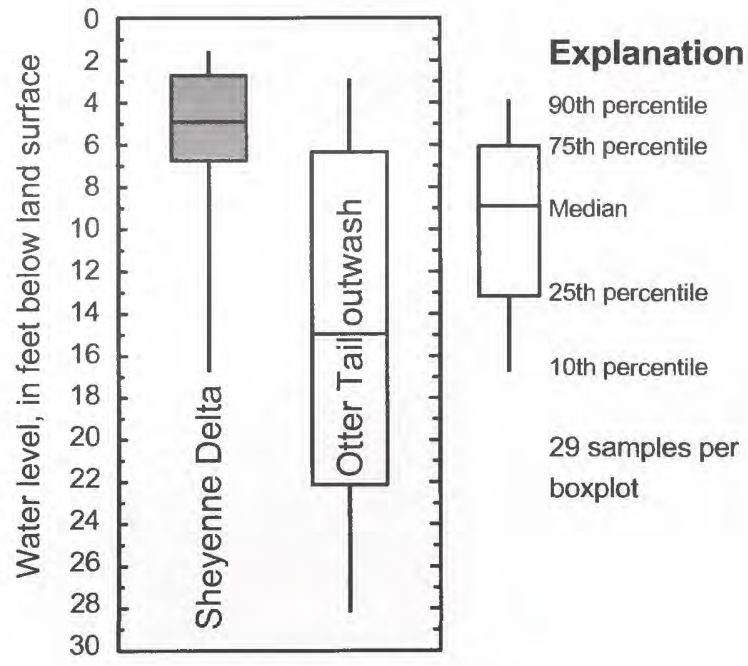

Figure 14-Water levels during sampling of ground water from land-use study areas.

This soil-zone-mediated biodegradation mechanism may also be enhanced in the Sheyenne Delta study area because of its large areas of long-untilled grassland. Although the well contributing areas which were grassland and pasture in the Sheyenne Delta study area were actually smaller than that in the Otter Tail outwash study area, much of this area in the Otter Tail outwash study area is in the Conservation Reserve Program and was under cultivation within the last 10 years. Much of the grassland area in the Sheyenne Delta study area has been out of cultivation since the drought years of the 1930's. This grassland, and the Sheyenne National 
Grassland that is interspersed within the study area, probably has developed or retained a thicker, deeper soil zone than have grassland areas in the Otter Tail outwash study area. This means that percolating water or shallow ground water may spend more time in contact with the soil zone in the Sheyenne Delta study area where biodegradation can remove more agricultural chemicals.

The greater depth to water and higher percolation velocities in the Otter Tail outwash also explains why ammonia concentrations in Otter Tail outwash shallow ground water were one-half those measured in Sheyenne Delta shallow ground water. The coarser-grained aquifer material and greater depth to water in the Otter Tail outwash study area allow shallow ground water to remain oxygenated because percolating water passes relatively quickly through the soil zone. Decaying plant or animal matter or ammonia from agricultural application that does not undergo nitrification or vaporization are sources of ammonia found in shallow ground water. When carried with percolating water to oxygenated ground water, as happens in the Otter Tail outwash aquifer, ammonia is oxidized to nitrate. If such ammonia is carried to anoxic ground water, it remains as ammonia. Alternatively, ammonia which has oxidized to nitrate and is then transported to the water table with percolating water, may be reduced back to ammonia in anoxic ground water like that in the Sheyenne Delta aquifer.

Differences in ground-water travel time and changes in land use with time between the study areas can also help explain higher nitrate concentrations in the shallow ground water from the Otter Tail outwash study area. Because ground water moves more slowly in the Sheyenne Delta aquifer, the land use that affected the sampled water occurred longer ago than it did in the Otter Tail outwash study area. The average time for recharging water to reach a well is estimated to be 11 years in the Sheyenne Delta study area and 4 years in the Otter Tail outwash study area. Both irrigation and agricultural chemical use have increased monotonically during the last 15 years in both study areas (Cowdery and others, 1995) as the age-date nitrate results from the flow-path transect samples suggest. Therefore, the concentrations of agricultural chemicals measured in the shallow ground water from the Sheyenne Delta aquifer may be lower, in a small part, because some wells in this study area sample slightly older water, affected by less irrigation and chemical application. These wells were screened deeper and were uninfluenced by the large recharge just before sampling in both study areas. Because ground water flows from the surface to these deeper sampled wells more quickly in the Otter Tail outwash study area, the water quality measured at these wells more closely represents the effects of recent land use. The full effect of land uses on shallow groundwater quality in the Sheyenne Delta aquifer may not be known for more than a decade afterward.

The high lignite and pyrite content of Sheyenne Delta aquifer sediments is another feature of the area that may contribute to low concentrations of nitrate in shallow ground water in this study area. These minerals are ubiquitous in the larger-than-silt fraction of the aquifer material and provide an energy source for denitrifying bacteria that oxidize the sulfur contained in these minerals to sulfate. Therefore, even when nitrate is not reduced during transport through the soil zone, denitrifying bacteria may reduce it deeper in the aquifer. This mechanism has been proposed by Korom and others (1996) to explain increasing sulfate and decreasing nitrate concentrations with depth in the Elk Valley aquifer (Mayer, 1992), a deposit similar to the Sheyenne Delta about 120 miles north. This trend has also been documented in Germany, Denmark, and the Netherlands (Korom and others, 1996). Patch and Padmanabhan (1994) used nitrogen isotopes to show that denitrification was responsible for the nitrate decrease with depth in the Elk Valley aquifer. Similar trends in concentrations of sulfate and nitrate with depth were not found during this study in water from the Sheyenne Delta aquifer, but these land-use wells provided almost no opportunity to measure concentration changes with depth because shallow ground water was the sampling target and because nitrate concentrations in the shallow ground water were already very low. The Sheyenne Delta flow-path transect wells contain water in which nitrate concentration decreased with depth, but sulfate concentrations did not vary consistently with depth. The Otter Tail outwash aquifer is not known to contain coal or pyrite minerals, but soil amendments with gypsum (a sulfate mineral) several decades ago have been reported (L. Puckett, U.S. Geological Survey, personal communication, 1996), complicating the sulfate distribution in the aquifer.

The relatively coarse-grained aquifer material composing the Otter Tail outwash aquifer also contributed to increased agricultural chemical concentrations in the shallow ground water because this material contains little clay. Nitrates and herbicides both readily sorb to clay. Therefore, in order to maintain proper levels of nutrients in the soil for plant growth in clay-poor soils, less fertilizer must be applied more frequently. In irrigated fields, this is economical 
because nutrients can be applied through irrigation water. But in the $46 \%$ of the Otter Tail outwash study area on which row crops or hay is grown without irrigation, application of fertilizer and herbicides involves extra work and this application may not be optimized for plant uptake of these chemicals. Nutrients and herbicides may be lost to the ground water because the soil and aquifer material do not contain enough clay to hold them until consumed by plants or degraded by soil bacteria. If nutrients or herbicides move to the ground water, they are unavailable to benefit crop production and more must be applied to sustain crop yield. In this way, the coarser-grained soils and aquifer material of the Otter Tail outwash aquifer can help lead to the increased chemical use estimated for this study area and the increased agricultural chemicals found in the shallow ground water there.

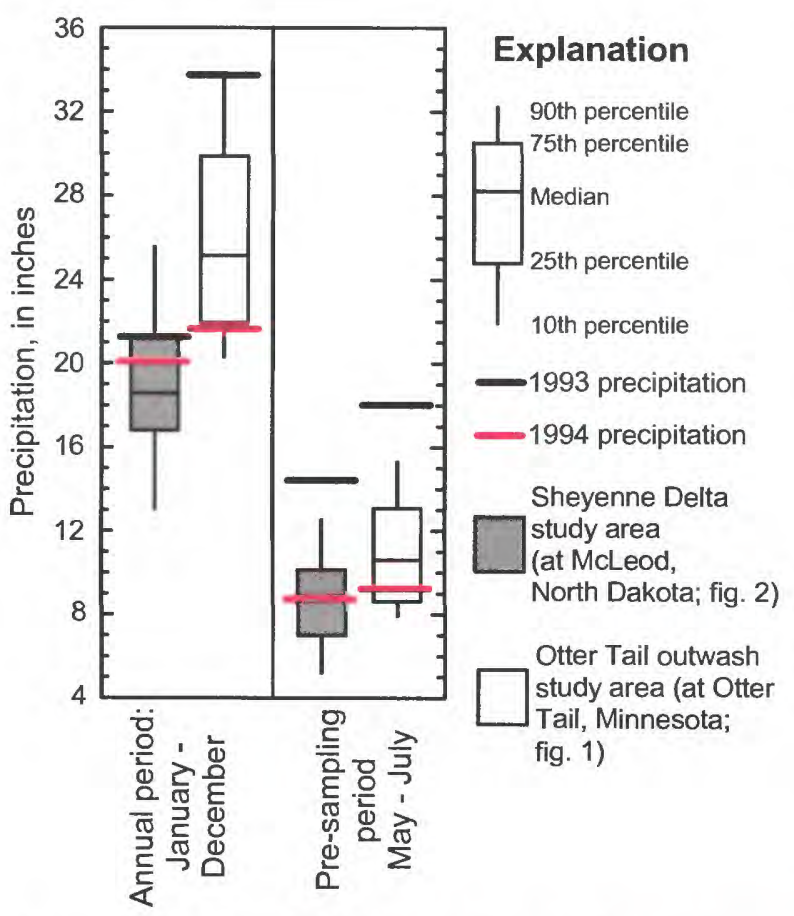

Figure 15-Precipitation in the study areas, based on 1966-95 data.

\section{Rainfall}

Rainfall differences during the sampling periods had a clear effect on agricultural chemical concentrations determined in these studies. The three-month period immediately before sampling in the Sheyenne Delta study area (May through July 1993) was extremely wet ( $161 \%$ of the 30 -year median). The equivalent period in the Otter Tail outwash study area (May through July
1994) was somewhat drier than normal $(88 \%$ of the 30 year median, fig. 15). The pre-sampling period of the Sheyenne Delta study area was also cooler than normal, and came a year after the end of a drought from 1987 through 1991. This drought is reflected in the low water levels during this period, apparent in the hydrograph of well SD13 (typical for the Sheyenne Delta aquifer, fig. 16). Ground-water recharge from precipitation in 1992 and particularly in the spring and early summer of 1993 caused water levels in this well to rise nearly $6 \mathrm{ft}$ in about 16 months, to nearly $2 \mathrm{ft}$ below land surface. The water level after this rise was the highest in 17 years and occurred just before sampling began in the Sheyenne Delta study area. The rise brought the water table from well below, up into contact with, the soil zone.

The effects of this weather on ground-water quality in the Sheyenne Delta aquifer were significant. Cowdery and Goff (1993) calculated a historical median nitrate concentration in the aquifer of $0.19 \mathrm{mg} / \mathrm{L}-\mathrm{N}$ from samples collected during July and August, but only in years of normal rainfall (the middle $75 \%$ of years). These historical samples were collected from domestic, irrigation, and observation wells that were screened generally deeper than the land-use wells. Therefore, based on the vertical nitrate distribution measured in samples from flow-path transect wells, the historical nitrate concentrations should have been lower than in the surficial ground water measured in 1993. However, the 1993 surficial ground-water median concentration was an order of magnitude lower $(0.02 \mathrm{mg} / \mathrm{L}-\mathrm{N})$, the difference being statistically significant at the $99 \%$ confidence level.

Other mechanisms besides enhanced biodegradation from ground water/soil zone contact help explain this difference. These include reduced application of agricultural fertilizers because fields were too wet to work, and nitrate consumption by algae in ponded water where the water table intersected the land surface (Cowdery and Goff, 1993). It is also possible that water, recharged during spring snowmelt and containing nitrates leached from fields, was overlain by later recharge that was low in nitrates, because all nitrates had been leached earlier and fields were too wet to apply more fertilizer. The land-use wells, screened at the water table, may have yielded this nitrate-poor water and not the nitrate-rich water just below. Cowdery and Goff (1993) present evidence that a nitrate maximum existed about 1-3 ft below the water table in the 29 samples forming the 1993 land-use data.

Radig and Bartelson (1994) reported water quality results of 60 samples of Sheyenne Delta ground water collected in June 1994, about one year after the land- 


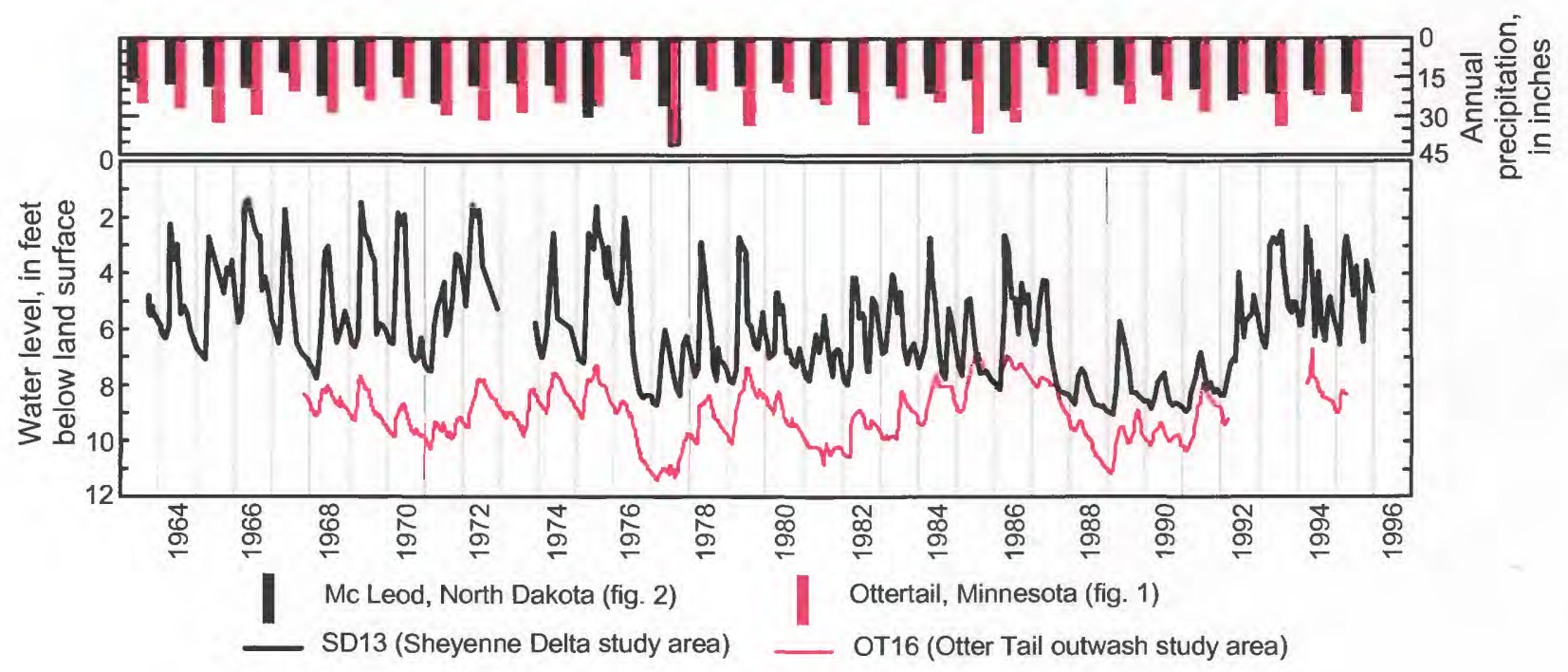

Figure 16-Exemplar hydrographs from the land-use study area.

use study samples were collected. These samples came from domestic, irrigation and observation wells, $58 \%$ of which were completed deeper than $10 \mathrm{ft}$ below the water table. Because these samples came from deeper within the aquifer than did the land-use samples in 1993, they should contain lower concentrations of nitrate and pesticides. Nitrate concentrations in the 1994 ground water were virtually the same as those in the 1993 surficial ground water, however. Further, when comparing the pesticides sampled in both years and setting detection limits equal, $22 \%$ of the 1994 ground water contained at least one measurable pesticide compared to $10 \%$ of the 1993 surficial ground water. Therefore, 1994 Sheyenne Delta ground water contained higher concentrations of nitrate and pesticides than expected. The deeper sampling interval of the 1994 samples may have produced somewhat older water than did the wells sampled in 1993. If some of the 1994 water were 2 or more years old, it would not have been affected by the mechanisms that account for the lower nitrate and pesticide concentrations found in 1993 shallow ground water and, therefore, would contain the higher agricultural chemical concentrations measured.

A drought during 1987 through 1992 also affected the Otter Tail outwash study area. Water levels during the drought were not depressed as far relative to previous years in well OT16 (typical for the Otter Tail outwash aquifer, fig. 16) as they had been in well SD13. Also, because water levels in the Otter Tail outwash study area are generally well below the soil zone, the rise in these levels after the drought did not affect chemical concentrations in the ground water through mechanisms involving soil biodegradation, field flooding or biological consumption at the land surface.

\section{Implications of Study Results}

The land-use and hydrogeological differences between these two study areas collectively can explain why concentrations of agricultural nutrients and pesticides were higher in the shallow ground water in the Otter Tail outwash aquifer in 1994 than in the Sheyenne Delta aquifer in 1993. The large amount of rain that fell just before sampling in the Sheyenne Delta study area accentuated these water-quality differences. Because the hydrogeological differences are perennial, and many land-use activities are responses to soil conditions, the ground-water quality in the Otter Tail outwash aquifer is probably always more affected by land use than is that in the Sheyenne Delta aquifer. The water-quality factors that lead to greater agriculturalland-use effects on shallow ground-water quality are summarized in table 12. Using the principles in this table and the ground-water quality measured in these two land-use studies, general features about the groundwater quality in most other sandy, surficial aquifers in the Red River Basin can be deduced. These aquifers are common along the margins of the Glacial Lake Agassiz Basin (Red River Valley Lake Plain) and its upland areas (fig.1). If most of the water-quality factors of an aquifer tend toward those of the Sheyenne Delta aquifer, the ground-water quality in that aquifer will also likely tend toward that of the Sheyenne Delta aquifer. For example, the Elk Valley aquifer deposit was formed similarly to the Sheyenne Delta and is located 120 miles north of it. The amount of irrigated agriculture over the Elk Valley aquifer is much greater, however. Therefore, nitrate concentrations in shallow ground water in the Elk Valley aquifer may be similar to but somewhat higher than those measured in Sheyenne Delta 
Table 12. - Water-quality factors affecting agricultural-chemical concentrations in shallow ground water from sandy, surficial aquifers beneath cropland.

\begin{tabular}{|c|c|c|c|}
\hline Factor group & Water-quality factor & Effect of increasing factor & $\begin{array}{l}\text { Land-use area with } \\
\text { greater factor }\end{array}$ \\
\hline \multirow{3}{*}{ Land use: } & Crop and chemical application & 仓 Increases concentration & Otter Tail outwash \\
\hline & Cropping density & 仓 Increases concentration & Otter Tail outwash \\
\hline & Irrigation & 仓 Increases concentration & Otter Tail outwash \\
\hline \multirow[t]{4}{*}{ Hydrogeology: } & Aquifer grain-size & 仓̂ Increases concentration & Otter Tail outwash \\
\hline & Aquifer homogeneity & 仓̂ Increases concentration & Otter Tail outwash \\
\hline & $\begin{array}{l}\text { Water contact with soil zone } \\
\text { (decreasing dissolved oxygen) }\end{array}$ & $\sqrt{ }$ Decreases concentration & Sheyenne Delta \\
\hline & Pyrite and lignite content & ת Decreases concentration & Sheyenne Delta \\
\hline
\end{tabular}

shallow ground water. The specific agricultural pesticides present in the ground water of a certain aquifer is controlled by what crops are grown over the aquifer and what pesticides are used on those crops. Deductions about pesticide concentrations in the ground water of other aquifers in the basin, which are based on these results, are valid only for those pesticides used on the crops grown in the two areas studied.

\section{Drinking water implications}

The concentration of nitrate, atrazine, radon, and uranium in some samples of shallow ground water from the land-use studies approached or exceeded drinkingwater standards promulgated by the USEPA. At the concentrations of these standards, the first two chemicals are the result of agricultural land use. The second two chemicals are found naturally in the water. Of these chemicals, nitrate poses the most serious threat to the potability of shallow-ground water from the Otter Tail outwash aquifer. Over $40 \%$ of shallow ground water from this aquifer exceeded the drinking water maximum contaminant level (MCL) of $10 \mathrm{mg} / \mathrm{L}-\mathrm{N}$ (U.S. Environmental Protection Agency, 1996). No shallow ground water from the Sheyenne Delta aquifer exceeded this standard. In the two worst cases, nitrate concentrations were more than four times the standard. The USEPA has established drinking water MCLs for 4 of the 10 herbicides detected in the study areas (U.S. Environmental Protection Agency, 1996). In no case did a concentration exceed these limits. One sample of atrazine in the Otter Tail outwash study area approached the MCL of $3 \mu \mathrm{g} / \mathrm{L}$ ( $2.4 \mu \mathrm{g} / \mathrm{L}$, at well OT28), however.

When comparing the results of these land-use studies to USEPA drinking water standards, remember that the water sampled is the shallow ground water, specifically chosen to show the earliest and greatest effects of land use. Most drinking water wells are screened deeper in the aquifer. If people drink shallow ground water, it is usually diluted by water from deeper in the aquifer. Water withdrawn from deeper within the aquifer is older than shallow water and may have been recharged in an area with land use far different than that near the well. Samples collected from deeper wells along the flowpath transect demonstrate that this older water had low concentrations of agricultural chemicals and effectively dilutes herbicide and nutrient concentrations in shallow ground water when withdrawn by a drinking-water well with a long screened interval. The USEPA MCLs are specifically relevant for drinking water and are provided here only as a basis of comparison.

Based on the vertical stratification of agricultural chemicals in ground water measured in the flow-path transect wells, the concentrations measured in these land-use studies are likely to be greater than those found in most wells installed for domestic supply or irrigation in the aquifers. However, because shallow ground water will eventually become overlain by younger, recharging water, and because degradation processes within the aquifer may become overwhelmed as input concentrations increase, these chemical concentrations can eventually affect the entire aquifer. In this sense, the concentrations determined in these studies can serve as an early warning about the ground-water-quality changes throughout the aquifer resulting from agricultural land use over these aquifers.

\section{Effects on gaining streams}

In addition to implications for the ground-water quality in other sandy surficial aquifers in the basin and water potability, effects of the discharge of this 
agriculturally-influenced ground water to lakes and streams also may be important. Both of these aquifers are hydraulically connected to the major rivers that cross them and, in many cases, also to the ephemeral streams, ditches, wetlands and lakes within them. Discharge of nitrate-rich ground water to surface-water bodies can promote eutrophication, particularly during base-flow conditions on the major rivers when ground water comprises a significant portion of their flow (Paulson, 1983, and Reeder, 1972). Because shallow Otter Tail outwash ground water contains a median nitrate concentrations of $6.1 \mathrm{mg} / \mathrm{L}-\mathrm{N}$, increased nitrate concentrations might be expected in the Otter Tail River as it crosses the aquifer. The surface-water component of this NAWQA study included sampling on the Otter Tail River to document this kind of ground-waterdischarge effect (Tornes and others, 1994, and Puckett and others, 1995). No such effect was measured, however.

Measurements made during base flow in winter 199394, determined the contribution of ground water from the Otter Tail outwash aquifer to the flow of the Otter Tail River at a point 1 mile downstream of the flow-path transect discharge area (fig. 8, flow-path transect well 1) to be as much as $20 \%$ (14.8 $\mathrm{ft}^{3}$ per second). This discharge entered the river along 5.2 miles upstream of the measuring point where the river crosses the aquifer. During 1993-94, nitrate concentrations in the river ranged from less than 0.05

to $0.65 \mathrm{mg} / \mathrm{L}-\mathrm{N}$. Assuming that the nitrate concentration in surface runoff is zero (frozen conditions during the winter), and that all chemicals entering the river are from ground-water discharge of the Otter Tail outwash aquifer containing the median nitrate concentration of $6.1 \mathrm{mg} / \mathrm{L}-\mathrm{N}$, only about one-half as much of the river flow (11\%) could come from ground water to achieve a river nitrate concentration of $0.65 \mathrm{mg} / \mathrm{L}-\mathrm{N}$. Therefore, the median concentration of nitrate in ground water discharging to the river must be at most $3.3 \mathrm{mg} / \mathrm{L}-\mathrm{N}$. A mass-balance calculation assumed that ground water from the entire thickness of the aquifer, and with the vertical distribution of nitrate measured at well nest 1 (fig. 10), contributed equally to the discharge to the Otter Tail River. The results indicated that dilution of nitrate-rich shallow ground water with nitrate-poor deeper ground water alone could not account for the low nitrate concentrations measured in the Otter Tail River during base flow, and that denitrification is occurring in the aquifer somewhere near the discharge areas.

An analysis of orthophosphorus loads indicates that ground water is delivering roughly 900 pounds per year to the Otter Tail River in the same 5.2 mile reach. Although the median orthophosphorus concentration in shallow ground water in the study area was less than $0.01 \mathrm{mg} / \mathrm{L}-\mathrm{P}$, concentrations at flow-path transect well nest 1 were $0.02 \mathrm{mg} / \mathrm{L}-\mathrm{P}$ throughout the thickness of the aquifer except at the deepest well were it ranged from less than 0.01 to $0.22 \mathrm{mg} / \mathrm{L}-\mathrm{P}$. Because this deepest well contributes least to discharge to the river and because such high levels of orthophosphorus were unusual both at this well and in the land-use study wells, I estimate a conservative orthophosphorus concentration of $0.03 \mathrm{mg} / \mathrm{L}-\mathrm{P}$ for ground water entering the Otter Tail River. Assuming that ground-water discharge and orthophosphorus concentration is fairly constant throughout the year $\left(14.8 \mathrm{ft}^{3}\right.$ per second, $0.03 \mathrm{mg} / \mathrm{L}-\mathrm{P}$ respectively), 874 pounds of orthophosphorus enters the river along this reach per year. This amounts to $25-50 \%$ of the total annual 1995-96 orthophosphorus load in the river at this point (U.S. Geological Survey, unpublished data).

A detailed study of ground-water nitrate and nitrogen-gas concentrations and oxidation/reduction state in ground water at the end of the Otter Tail flowpath transect demonstrated that significant denitrification was occurring beneath a riparian wetland located between the last flow-path transect well nest and the Otter Tail River (Puckett and others, 1995). This denitrification appears to occur as nitrate-rich ground water encounters the organic-rich sediments (peat) of the wetland and subjacent alluvium (fig. 10).

Denitrifying bacteria oxidize this organic material with oxygen from nitrate, producing nitrous oxide and nitrogen gas. Furthermore, shallow, nitrate-rich ground water mixes with deeper, nitrate-poor ground water that discharges near the river. Therefore, it appears that what would otherwise be a eutrophication threat from nitraterich ground water in the Otter Tail outwash aquifer, is ameliorated by the riparian wetlands that exist along much of the Otter Tail River in the study area. The Sheyenne Delta does not have these kinds of wetlands; however, the nitrate concentration in ground water discharging to this river is low, so no evaluation of the hypothesis is possible in that area. Similar data is equivocal about orthophosphorus removal beneath riparian wetlands. However, because the median concentration of orthophosphorus in both shallow ground water and the rivers was less than $0.01 \mathrm{mg} / \mathrm{L}-\mathrm{P}$ in both areas during these studies, orthophosphorus in ground water is unlikely to cause eutrophication presently. A small percentage ground water contained concentrations as high as $0.22 \mathrm{mg} / \mathrm{L}-\mathrm{P}$ in the Otter Tail outwash aquifer and $0.34 \mathrm{mg} / \mathrm{L}-\mathrm{P}$ in the Sheyenne Delta aquifer. Orthophosphorus concentrations in this range 
could cause eutrophication in surface-water bodies if they became prevalent throughout the aquifers.

\section{Summary}

Ground-water quality in the two largest surficial aquifers in the Red River of the North Basin were quite different. Although these ground waters were both fairly dilute, dominated by calcium, magnesium, and bicarbonate ions, shallow ground water from the Otter Tail outwash aquifer contained much higher concentrations of chemicals from agricultural land uses than did that from the Sheyenne Delta aquifer. Major similarities and differences in water quality between the two study areas, documented during 1993-95, are summarized in table 13. No obvious spatial pattern appeared in nitrate concentrations in either study area. Triazine herbicides were the most commonly detected herbicides and were detected at the highest concentrations in the shallow ground water of both aquifers. One sample from the Sheyenne Delta aquifer contained a high concentration of picloram. Agricultural chemicals in ground water in both study areas show strong vertical stratification. Concentrations were highest at the water table, but decrease to undetectable with depth. Ground water age repeated this pattern, with the youngest water at the water table and age increasing to about 50 years at depth. Complex seasonal variations in agricultural-chemical concentrations also occurred in these shallow ground waters. These variations ranged about one-half an order of magnitude and were not consistent between locations. Some locations showed seasonal fluctuations where nitrate concentrations decreased during recharge periods.

Differences in land use, hydrogeology, and rainfall between the study areas are responsible for these differences in shallow ground-water quality. The Otter Tail outwash study area had $9 \%$ more cropland, twice as much nutrient application, $17 \%$ more pesticide application, and 7 times as much irrigated cropland than did the Sheyenne Delta study area. Further, shallow ground-water quality in the Sheyenne Delta aquifer can reflect agricultural practices up to a decade or more old because of relatively slow ground-water-flow velocities. These older practices applied less agricultural chemicals to the land surface. Finally, national grassland areas that were interspersed throughout the Sheyenne Delta study area diluted agricultural-chemical applications from other land uses. This dilution affected deeper ground-water quality, but had little effect on the surficial ground-water quality measured in these studies because most areas of the aquifer have downward ground-water flow. These land-use factors all contributed to relatively higher agricultural-chemical concentrations in shallow ground water in the Otter Tail outwash study area.

Several hydrogeological characteristics of the Sheyenne Delta aquifer encourage denitrification and biological degradation of pesticides and contributed to the relatively lower agricultural chemical concentrations in the shallow ground water from this aquifer. These characteristics include those likely to allow chemicals in water longer contact with the soil zone, depleting dissolved oxygen. Deeper water levels within the soil zone, finer-grained and more poorly sorted aquifer material and soils, and high lignite and pyrite (microbial energy source) content of the Sheyenne Delta aquifer all deplete oxygen, contributing to biodegradation and thereby lowering concentrations of agricultural chemicals in the shallow ground water. The coarsergrained soil and aquifer material of the Otter Tail outwash aquifer mean less clay is available to hold nutrients and pesticides in the soil zone where plants can use them or bacteria can degrade them. More nutrients and pesticides may be applied to maintain yields and may move to the shallow ground water in this study area.

High rainfall immediately preceding sampling in the Sheyenne Delta study area further reduced concentrations of agricultural chemicals relative to the Otter Tail outwash study area. The rainfall caused water levels to rise higher into the soil zone, encouraging denitrification and biodegradation of agricultural chemicals. Fields were too wet for planting or chemical application thereby reducing chemical sources. Algae and bacteria growing in water ponded in fields, consumed chemicals before they could infiltrate to the water table. Finally, increased ground-water recharge from the high rainfall may have leached chemicals from the soil, and carried them to the water table where the chemicals were overlain by recharge beneath the screened intervals of the sampled wells. These mechanisms, operating to reduce agricultural-chemical concentrations in shallow Sheyenne Delta ground water, accentuated the differences in water quality between the two study areas.

The land-use, hydrogeological, and rainfall factors outlined above explain the shallow ground-water-quality differences determined in these study areas. These same factors, measured in other surficial aquifers in the Red River Basin can reveal expected shallow ground-water quality in other areas. Because these studies measured shallow ground-water quality, the concentrations of agricultural chemicals measured in these studies are 
Table 13. - Shallow ground-water-quality summary from land-use study areas.

[mg/L, milligrams per liter; $\mu \mathrm{g} / \mathrm{L}$, micrograms per liter; $\mathrm{N}$, nitrogen; $\mathrm{P}$, phosphorus; \%, percent; $\geq$, greater than or equal to; $\%$, percent; <, less than; DL, detection limit]

\begin{tabular}{lllc}
\hline \multicolumn{1}{c}{ Solute } & Sheyenne Delta aquifer & $\begin{array}{c}\text { Otter Tail outwash } \\
\text { aquifer }\end{array}$ & $\begin{array}{c}\text { Significantly } \\
\text { different?* }\end{array}$ \\
\hline Major ions & $\begin{array}{l}\text { calcium-magnesium } \\
\text { bicarbonate }\end{array}$ & $\begin{array}{l}\text { calcium-magnesium } \\
\text { bicarbonate }\end{array}$ & - \\
Oxygen median & $<0.1 \mathrm{mg} / \mathrm{L}$ & $3.6 \mathrm{mg} / \mathrm{L}$ & Yes \\
Nitrate median & $.03 \mathrm{mg} / \mathrm{L}$ as N & $6.1 \mathrm{mg} / \mathrm{L}$ as N & Yes \\
Ammonia median & $.04 \mathrm{mg} / \mathrm{L}$ as N & $.02 \mathrm{mg} / \mathrm{L}$ as N & Yes \\
Orthophosphorus & $10 \% \geq 0.05 \mathrm{mg} / \mathrm{L}$ as P & $14 \% \geq 0.05 \mathrm{mg} / \mathrm{L}$ as P & No \\
Number of different herbicides detected & 6 & 10 & - \\
Proportion containing some pesticide & $17 \%$ & $76 \%$ & Yes 1 \\
Median total pesticide concentration & $<\mathrm{DL}$ & $.023 \mu \mathrm{g} / \mathrm{L}$ & Yes \\
\hline
\end{tabular}

* Statistically significant at the $95 \%$ confidence level using the Wilcoxon rank-sum test.

${ }^{1}$ Significant at the $95 \%$ confidence level using the $\chi^{2}$ test.

likely higher than those in the drinking water pumped from these aquifers. Eventually, however, the shallow ground water will be overlain by subsequent recharge, may overwhelm denitrification which may occur within the aquifer, and may eventually affect the entire aquifer. In this way, the concentrations measured in these studies are an early warning of the effects of land use on ground water in these surficial aquifers. Both nitrate and atrazine concentrations approached or exceeded USEPA drinking water standards in the shallow-ground water from Otter Tail outwash aquifer. Forty three percent of the Otter Tail outwash shallow ground water exceeded USEPA nitrate drinking water standard of $10 \mathrm{mg} / \mathrm{L}-\mathrm{N}$. Nitrate threatens the potability of shallow ground water in the Otter Tail outwash study area. Although the Otter Tail River receives as much as $20 \%$ of its flow from ground water, nitrate does not threaten the river with eutrophication because riparian wetlands denitrify the ground water before it reaches the river. Although agriculture has an effect on the quality of shallow ground water in both the Sheyenne Delta and Otter Tail outwash aquifers, the effect is much greater in the Otter Tail outwash aquifer because the agriculture in the area is more intense and because the hydrogeology of the aquifer does not favor degradation of agricultural chemicals.

\section{References}

Alexander, R.B., and Smith, R.A., 1990, County-level estimates of nitrogen and phosphorus fertilizer use in the United States, 1945 to 1985: U.S.

Geological Survey Open-File Report 90-130, 12 p.
American Society for Testing and Materials, 1996a, Annual book of ASTM standards, section 11: Water and Environmental Technology, v. 11.02, D5174-91, p. 699-701.

1996b, Annual book of ASTM standards, section 11, Water and Environmental Technology: v. 11.02, D5072-92, p. 674-676.

Armstrong, C.A., 1982, Ground water resources of Ransom and Sargent Counties, North Dakota: North Dakota Geological Survey Bulletin 69Part III, 51 p., 2 plates.

Baker, Jr., C.H., 1967, New observations on the Sheyenne Delta of Glacial Lake Agassiz, in Geological Survey Research 1967: U.S. Geological Survey Professional Paper 575-B, p. B62-B68.

Baker, Jr., C.H., and Paulson, Q.F., 1967, Geology and ground water resources Richland County, North Dakota, Part III, Ground Water Resources: North Dakota Geological Survey Bulletin 46, 47 p., 1 plate.

Boehlke, J.K., Wanty, R.B., Tuttle, M.L., Landon, M.K., and Delin, G.N., 1994, Resolving the effects of varying land use and aquifer reactions on nitrate contamination of ground water in Central Minnesota: in EOS, Transactions, American 
Geophysical Union 1994 Spring Meeting Abstract Supplement, v. 75, no. 16, p. 154.

Brophy, J.A., and Bluemle, J.P.. 1983, The Sheyenne River-Its geologic history and effects on Lake Agassiz, in Teller, J.T., and Clayton, L., eds., Glacial Lake Agassiz: Geological Association of Canada Special Paper 26, p. 173-185.

Busenburg, Eurybiades, and Plummer, L.N., 1992, Use of chlorofluorocarbons $\left(\mathrm{CCl}_{3} \mathrm{~F}\right.$ and $\left.\mathrm{CCl}_{2} \mathrm{~F}_{2}\right)$ as hydrologic tracers and age-dating tools-The Alluvium and Terrace System of Central Oklahoma: Water Resources Research, v. 28, no. 9, p. 2257-2283.

Cowdery, T.K., and Goff, Karin, 1993, Nitrogen concentrations near the water table of the Sheyenne Delta aquifer beneath cropland areas, Ransom and Richland Counties, North Dakota, in Proceedings North Dakota Water Quality Symposium: North Dakota Extension Service, 1994, Fargo, North Dakota, p. 89-102.

Cowdery, T.K., Stoner, J.D., and Lorenz, D.L., 1995, Distribution and movement of nitrate in a surficial outwash aquifer beneath irrigated cropland, northwestern Minnesota: EOS, Transactions, The American Geophysical Union 1995 Fall Meeting Abstract Supplement, v. 76, no. 46, p. F195.

Downey, J.S., and Paulson, Q.F., 1974, Predictive modeling of effects of the planned Kindred Lake on ground-water levels and discharge, southeastern North Dakota: U.S. Geological Survey WaterResources Investigations Report 30-74, 22 p.. 7 plates.

Fenton, M.M., Moran, S.R., Teller, J.T., and Clayton, Lee, 1983, Quaternary stratigraphy, and history of the southern part of the Lake Agassiz Basin, in Teller, J.T., and Clayton, L., eds., Glacial Lake Agassiz: Geological Association of Canada Special Paper 26, p. 49-74.

Fetter, C.W., 1994, Applied Hydrology, $3^{\text {rd }}$ ed.: Prentice-Hall, Inc., Upper Saddle River, New Jersey, p. 321-325

Fishman, M.J., 1993, Methods of analysis by the U.S. Geological Survey National Water Quality Laboratory-Determination of inorganic and organic constituents in water and fluvial sediments: U.S. Geological Survey Open-File Report 93-125, $217 \mathrm{p}$.

Freeze, R.A., and Witherspoon, P.A., 1967, Theoretical analysis of regional groundwater flow-2. Effect on water-table configuration and subsurface permeability variation: Water Resources Research, v. 3 , no. 2 , p. 623-634

Gilbert, G.K., 1885, The topographic features of lake shores: U.S. Geological Survey $5^{\text {th }}$ Annual Report, p. $69-123$.

Gilliom, R.J., Alley, W.M., and Grutz, M.E., 1995, Design of the National Water-Quality Assessment Program-Occurrence and distribution of waterquality conditions: U.S. Geological Survey Circular 1112, $33 \mathrm{p}$.

Goldstein, B.S., 1985, Stratigraphy, sedimentology, and Late-Quaternary history of the Wadena Drumlin Region, central Minnesota: Ph.D. Thesis, Department of Geology and Geophysics, University of Minnesota-Minneapolis, 216 p.

Harris, K.L., 1987, Surface geology of the Sheyenne River map area: North Dakota Geological Survey Atlas Series Map 15, sheet A1, 1 sheet.

Helsel, D.R., 1990, Less than obvious-statistical treatment of data below the detection limit: Environmental Science and Technology, v. 25, no. 12, p. 1767-1774.

Hem, J.D., 1989, Study and interpretation of the chemical characteristics of natural water: U.S. Geological Survey Water-Supply Paper 2254, $263 \mathrm{p}$.

Hopkins, D.G., 1996, Hydrologic and abiotic constraints on soil genesis and natural vegetation patterns in the sand hills of North Dakota: Ph.D. Thesis, Department of Soil Science, North Dakota State University-Fargo, 272 p.

Kelly, P.L., and Hines, J.W., 1992, 1990 pesticide use in rural Minnesota: State of Minnesota, Department of Agriculture, Agronomy Services Division, Environmental Quality Section, St. Paul, Minnesota, $157 \mathrm{p}$. 
Korom, S.F., Munsen, C., and Mayer, G.G., 1996, Denitrification by pyrite-Comparison of the Elk Valley aquifer to northern European aquifers, in Proceedings North Dakota Water Quality Symposium: North Dakota Extension Service, Fargo, North Dakota, p. 95.

Koterba, M.T., Wilde, F.D., and Lapham, W.W., 1995, Ground-water data-collection protocols and procedures for the National Water-Quality Assessment Program-Collection and documentation of water-quality samples and related data: U.S. Geological Survey Open-File Report 95-399, 113 p.

Kuchler, A.W., 1964, Potential natural vegetation of conterminous United States: American Geographical Society Special Publication 36 , $116 \mathrm{p}$.

Lapham, W.W., Wilde, F.D., and Koterba, M.T., 1995. Ground-water data-collection protocols and procedures for the National Water-Quality Assessment Program-Selection, installation, and documentation of wells, and collection of related data: U.S. Geological Survey Open-File Report 95-398, $69 \mathrm{p}$.

Lorenz, D.L. and Stoner, J.D., 1996, Sampling design for assessing water quality of the Red River of the North Basin, Minnesota, North Dakota, and South Dakota, 1993-1995: U.S. Geological Survey Water-Resources Investigations Report 96-4129. 2 sheets.

Madison, R.J., and Brunett, J.O., 1984, Overview of the occurrence of nitrate in ground water of the United States, in National Water Summary 1984: U.S. Geological Survey Water-Supply Paper 2275, p. 93-105.

Mayer, G.G., 1992, Denitrification in the Elk Valley aquifer, northeastern North Dakota: Ph.D. thesis, University of North Dakota, Grand Forks, 234 p.

McDonald, M.C., and Harbaugh, A.W., 1988, A modular three-dimensional finite-difference ground-water flow model: U.S. Geological Survey Techniques of Water-Resources Investigations, book 6. chapter A1, $586 \mathrm{p}$.
Menheer, M.A., and Brigham, M.E., 1997, National Water-Quality Assessment Program-Groundwater sampling methods and quality control for the Red River of the North Basin, 1993-1995. U.S. Geological Survey Water-Resources Investigations Report 96-4317, 34 p.

National Weather Service, 1996, World-wide web site: http://www.ncdc.noaa.gov/coop-precip.html.

Patch, J.C., and Padmanabhan, G., 1994, Investigation of vertical nitrate gradients in a shallow confined aquifer in North Dakota: North Dakota State Water Commission Water Resource Investigation $21,99 \mathrm{p}$.

Paulson, Q.F., 1964, Geological factors affecting discharge of the Sheyenne River in southeastern North Dakota, in Geological Survey Research 1964: U.S. Geological Survey Professional Paper 501-D, p. D177-D181.

1983, Guide to ground-water resources of North Dakota: U.S. Geological Survey Water-Supply Paper 2236, 25 p.

Pollock, D.W., 1989, Documentation of computer programs to compute and display pathlines using results from the U.S. Geological Survey modular three-dimensional finite-difference ground-water flow model: U.S. Geological Survey Open-File Report 89-381, 188 p.

Puckett L.J., Tornes, L.H., Cowdery, T.K., Brigham, M.E., and Stoner, J.D., 1995, The role of wetlands in reducing nitrogen loadings to the Otter Tail River in Minnesota: EOS, Transactions, The American Geophysical Union 1995 Fall Meeting Abstract Supplement, v. 76, no. 46, p. F186.

Radig, S., and Bartelson, N., 1994, North Dakota`s groundwater monitoring program-1994 report: North Dakota State Department of Health and Consolidated Laboratories, Division of Water Quality, Bismarck, N. Dak, 93 p.

Reeder, H.O., 1972, Availability of ground water for irrigation from glacial outwash in the Perham area, Otter Tail County, Minnesota: U.S. Geological Survey Water-Supply Paper 2003, 45 p., 3 plates. 
Rose, D.L., and Schroeder, M.P., 1995, Methods of analysis by the U.S. Geological Survey National Water Quality Laboratory-Determination of volatile organic compounds in water by purge and trap capillary gas chromatography/mass spectrometry: U.S. Geological Survey Open-File Report 94-708, 26 p.

Running, G.L., IV, 1995a, Post-glacial aeolian sand deposition on the Sheyenne Delta, southeastern North Dakota—Sand source, process, and paleoenvironmental implications [abs.]: Geological Society of America Abstracts with Program, v. 27, no. 3, p. 83.

1995b, Archaeological geology of the Rustad quarry site (32RI775) - An early archaic site in southeastern North Dakota: Geoarchaeology, v. 10 , no. 3, p. 183-204.

1996, The Sheyenne Delta from the Cass phase to the present-Landscape evolution and paleoenvironment, in Quaternary geology of the southern Lake Agassiz Basin: North Dakota Geological Survey Miscellaneous Series 82, p. 136-152.

Scott, J.C., 1990, Computerized stratified random siteselection approaches for design of a ground-waterquality sampling network: U.S. Geological Survey Water-Resources Investigations Report 90-4101, $109 \mathrm{p}$.

Smith, S.E., and Ruhl, J.F., 1995, Presence and distribution of nitrate and selected pesticides in surficial-sand aquifers and selected lakes, 1993-94, east Otter Tail County, Minnesota: U.S. Geological Survey Open-File Report 95-116, 18 p.

Stoner, J.D., Lorenz, D.L., Wiche, G.J., and Goldstein, R.M., 1993, Red River of the North Basin, Minnesota, North Dakota, and South Dakota: Water Resources Bulletin, v. 29, no. 4, p. 575-615.

Strobel, M.L., and Cowdery, T.K., 1994, Effects of the 1993 flood in ground-water levels and quality in the Sheyenne Delta aquifer, southeastern North Dakota [abs.]: Thirty-Ninth Annual Midwest Ground Water Conference, October 16-18, 1994, Bismarck, North Dakota, p. 1-2.
Tornes, L.H., and Brigham, M.E., 1993, Nutrients, suspended sediment, and pesticides in waters of the Red River of the North Basin, Minnesota, North Dakota and South Dakota, 1970-1990: U.S. Geological Survey Water-Resources Investigations Report 93-4231, 62 p.

Tornes, L.H., Puckett, L.J., Stoner, J.D., and Brigham, M.E., 1994, The effect of riparian wetlands in reducing nitrate-nitrogen from a sand and gravel aquifer to a stream [abs]: EOS, Transactions, The American Geophysical Union 1994 Fall Meeting Abstract Supplement, v. 75, no. 44, p. 261.

Upham, Warren, 1883, Catalogue of the flora of Minnesota, including its phous and vascular cryptogamous plants, indigenous, naturalized, and adventive, in Winchell, N.H., ed., The Geological and Natural History Survey of Minnesota, The $12^{\text {th }}$ Annual Report: State of Minnesota, Minneapolis, Minnesota, plate 1 .

1885, The geology of Otter Tail County, in Winchell, N.H. ed., The Geology of Minnesota, Vol. II of the Final Report: State of Minnesota, St. Paul, Minnesota, p. 534-561.

1895, The Glacial Lake Agassiz: U.S. Geological Survey Monograph, v. XXV, 658 p.

University of Minnesota Agricultural Extension Service, 1991, Cultural and chemical weed control in field crops: University of Minnesota Agricultural Extension Service publication AGBU-3157-S, $64 \mathrm{p}$.

U.S. Environmental Protection Agency, 1980, Prescribed procedures for measurement of radioactivity in drinking water, Method 903.0: EPA-600/4-80-032, Cincinnati, Ohio, p. 31-37.

1996, Drinking water regulations and health advisories: U.S. Environmental Protection Agency, $11 \mathrm{p}$.

Wanty, R.B., and Nordstrom, D.K., 1993, Natural radionuclides, in Alley W.M., ed., Regional Ground-Water Quality: Van Nostrand Reinhold, New York, New York, p. 423-441.

Werner, S.L., Burkhart, M.R., and DeRusseau, S.N., 1996, Methods of analysis by the U.S. Geological 
Survey National Water Quality Laboratory-

Determination of pesticides in water by carbopakb solid-phase extraction and high-performance liquid chromatography: U.S. Geological Survey Open-File Report 96-216, 42 p.

Wetzel, R.G., 1983, Limnology, $2^{\text {nd }}$ ed.: Saunders College Publishing, New York, New York, 293 p.

Winkelmann, D.A., and Klaine, S.J., 1991, Atrazine metabolite behavior in soil-core microcosms, in Somasundaram, L., and Coats, J.R., eds., Pesticide Transformation Products: American Chemical Society, Washington, D.C., 75 p.

Winter, T.C., Bidwell, L.E., and Maclay, R.W., 1969, Water resources of the Otter Tail River watershed west-central Minnesota: U.S. Geological Survey Hydrologic Investigations Atlas HA-296, 4 sheets.

Wrenshaw, R.L., Fishman, M.J., Grabbe, R.R., and Lowe, L.E., eds., 1987, Methods for the determination of organic substances in water and fluvial sediments: U.S. Geological Survey Techniques of Water-Resources Investigations, book 5 , chapter $A 3,80 \mathrm{p}$.

Wright, Jr., H.E., 1972, Quaternary history of Minnesota, in Sims, P.K. and Morey, G.B., ed., Minnesota-A Centennial Volume: Minnesota Geological Survey, St. Paul, Minnesota, p. $540-543$.

Zaugg, S.D., Sandstrom, M.W., Smith, S.G., and Fehlberg, K.M., 1995, Methods of analysis by the U.S. Geological Survey National Water Quality Laboratory-Determination of pesticides in water by c-18 solid-phase extraction and capillarycolumn gas chromatography/mass spectrometry with selected-ion monitoring: U.S. Geological Survey Open-File Report 95-181, 60 p.

Zollinger, R.K., McMullen, M.P., Dahl, G.K., Dexter, A.G., Nalewaja, J.D., Hamlin, W.G., and Beckler, D.G., 1992, Pesticide use and pest management practices for major crops in North Dakota 1992: North Dakota Extension Service, Extension Report No. 15, 67 p. 
Supplemental Information 


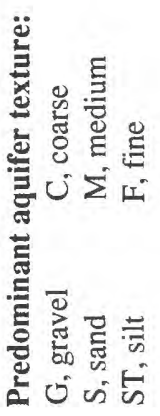

है

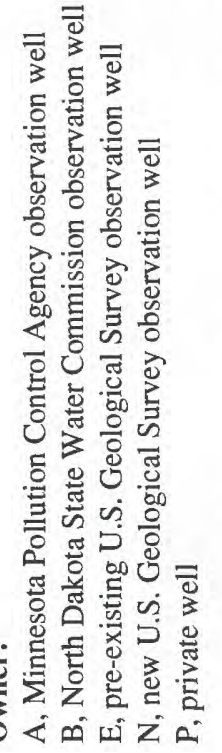

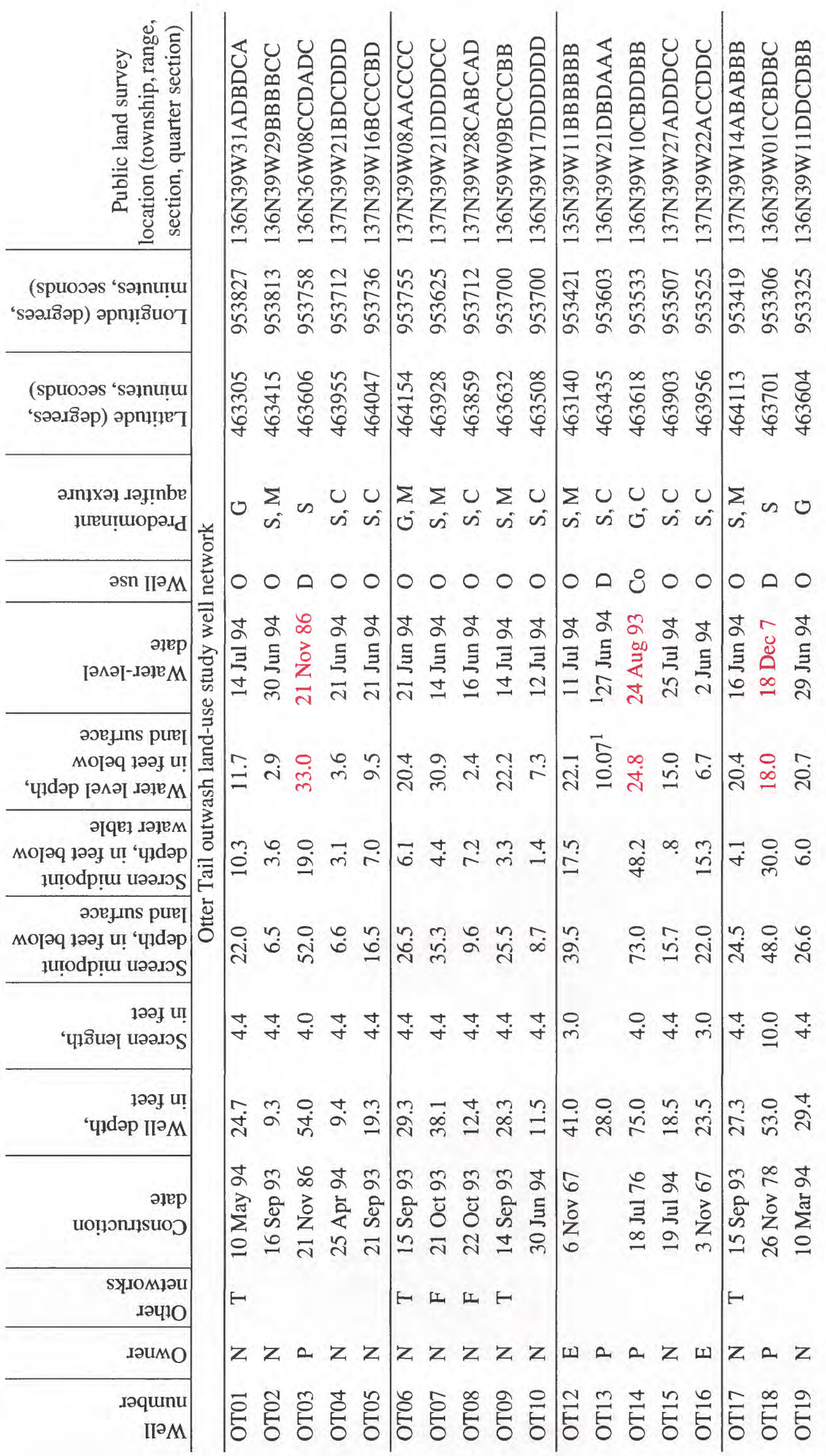




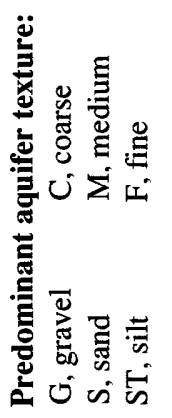

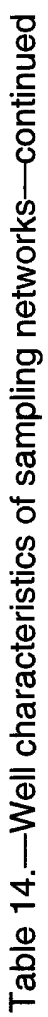

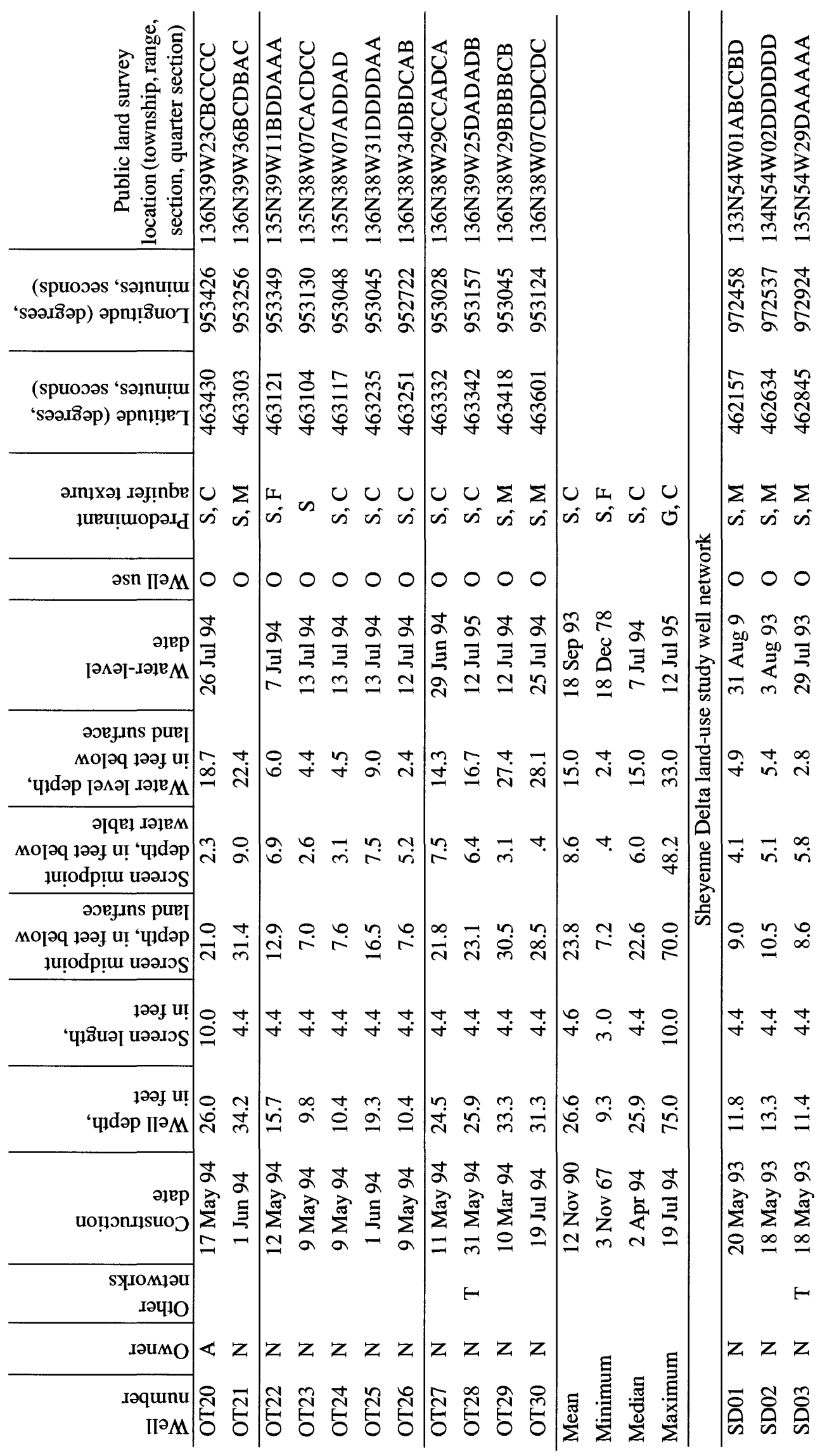



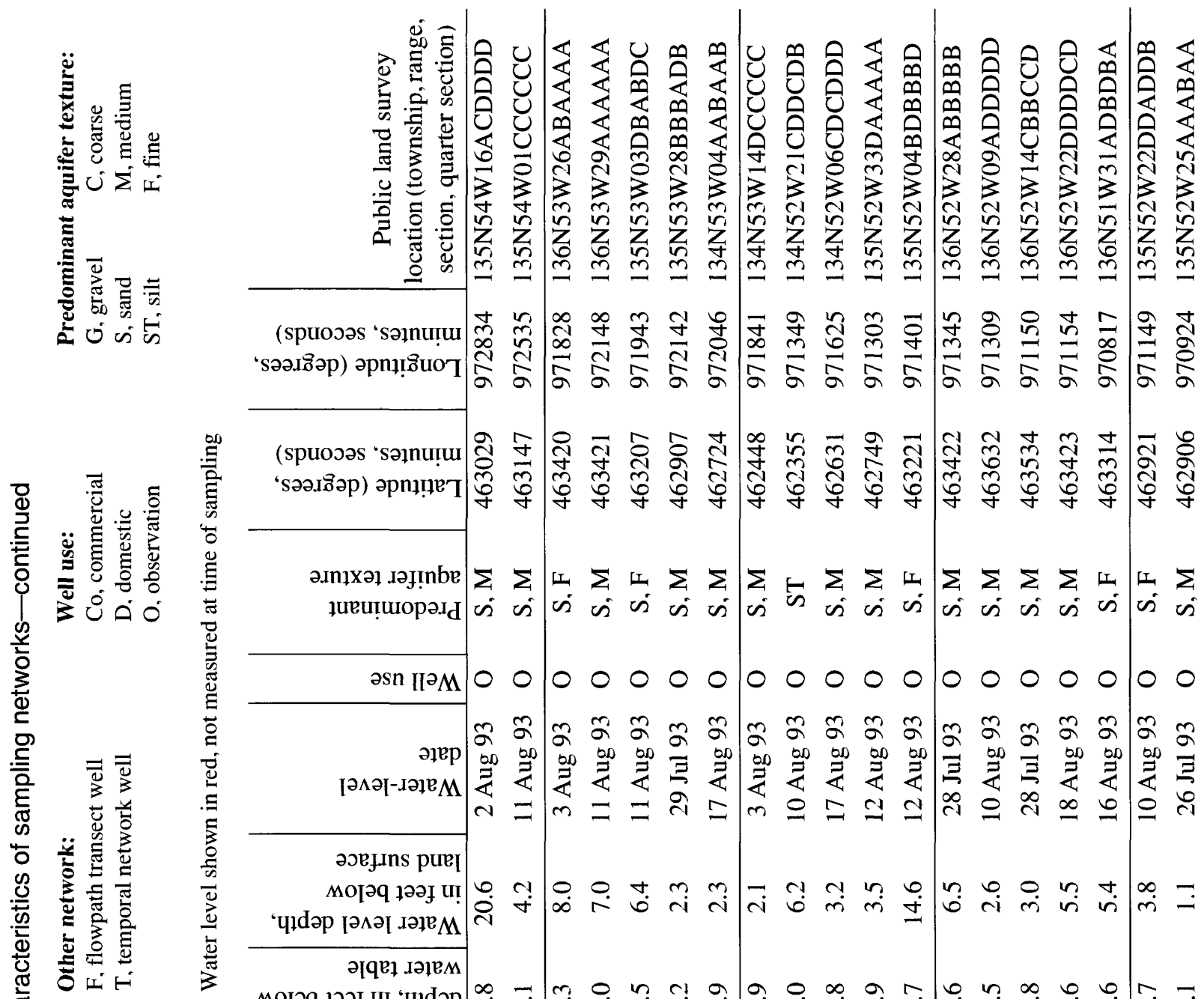

象舟

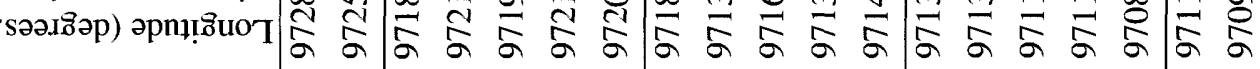

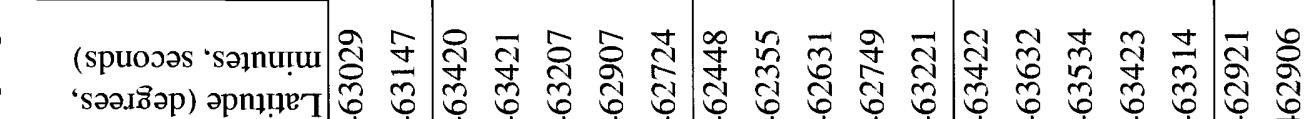

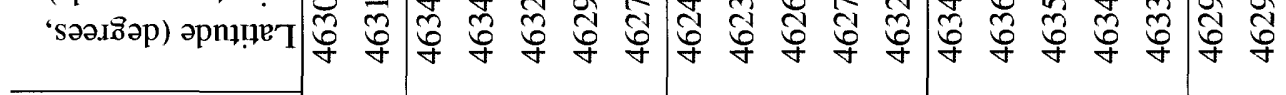
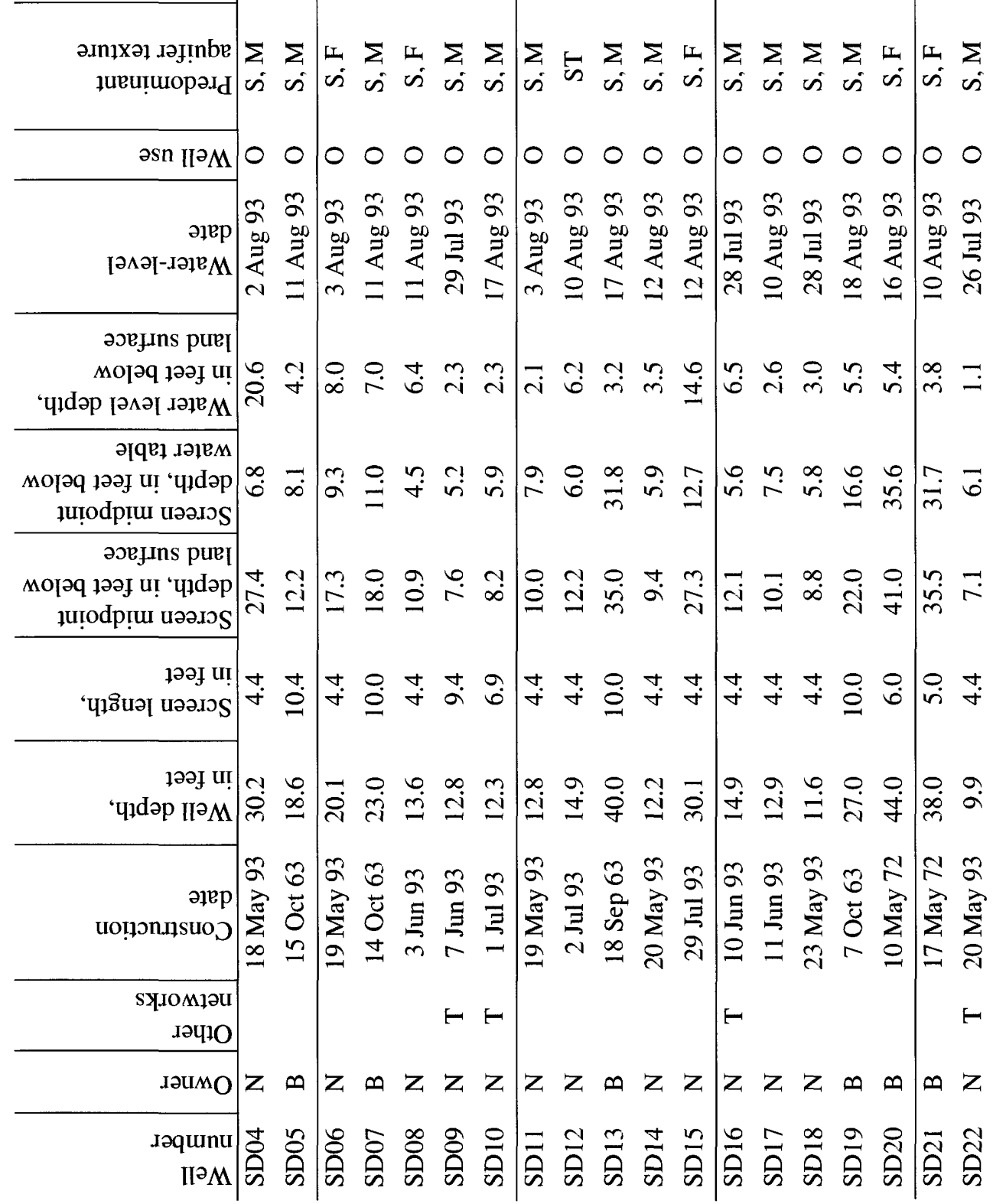

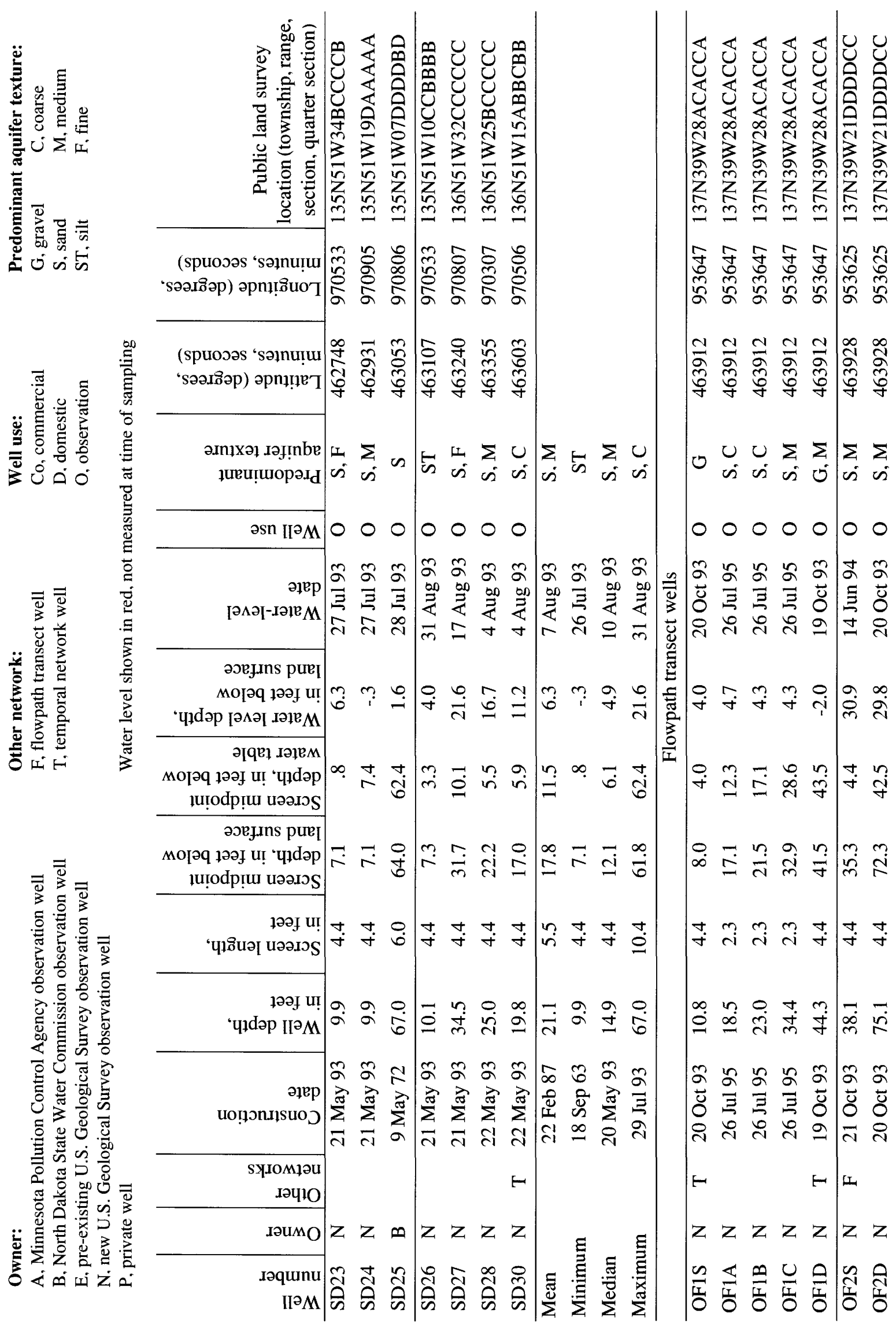

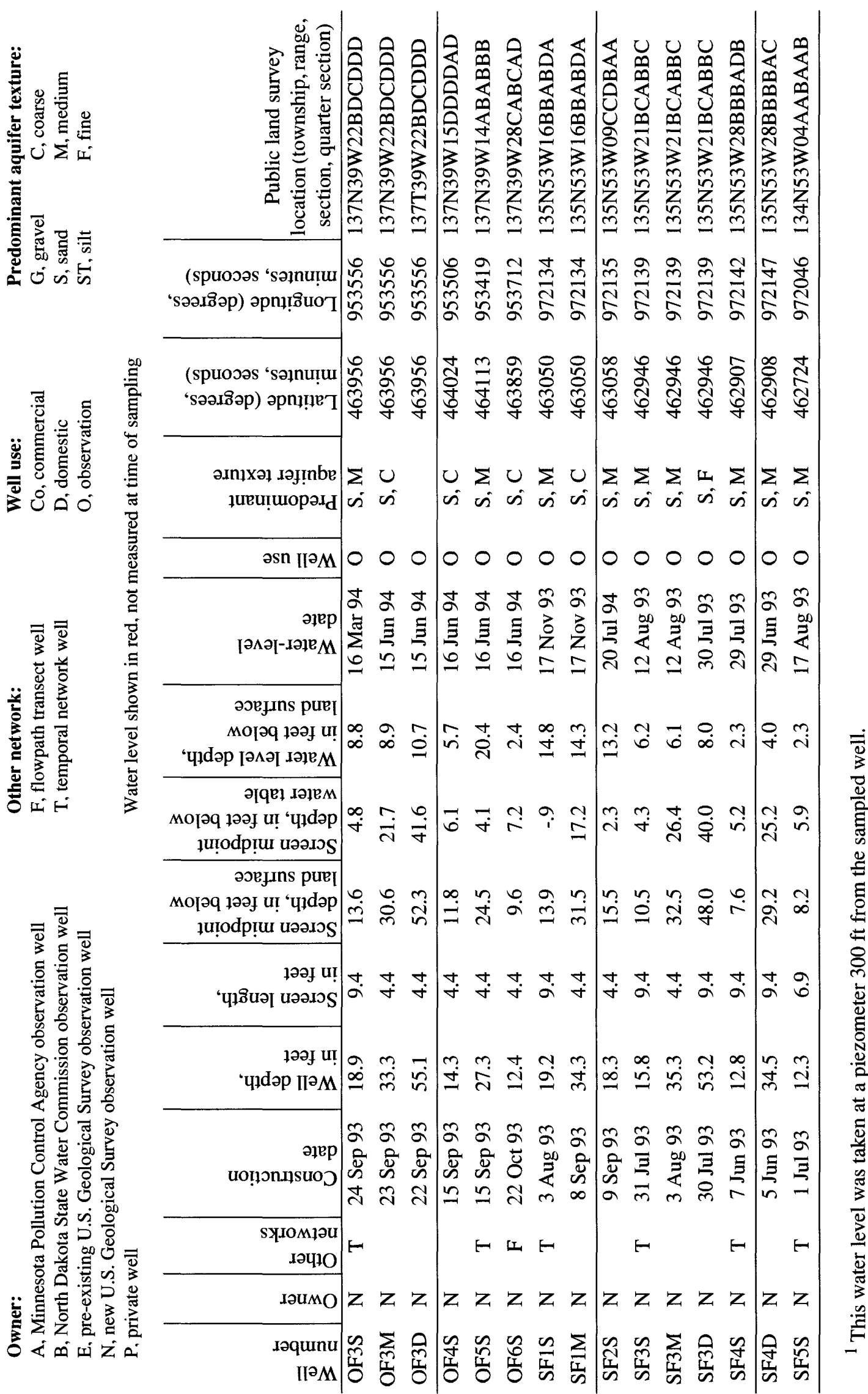

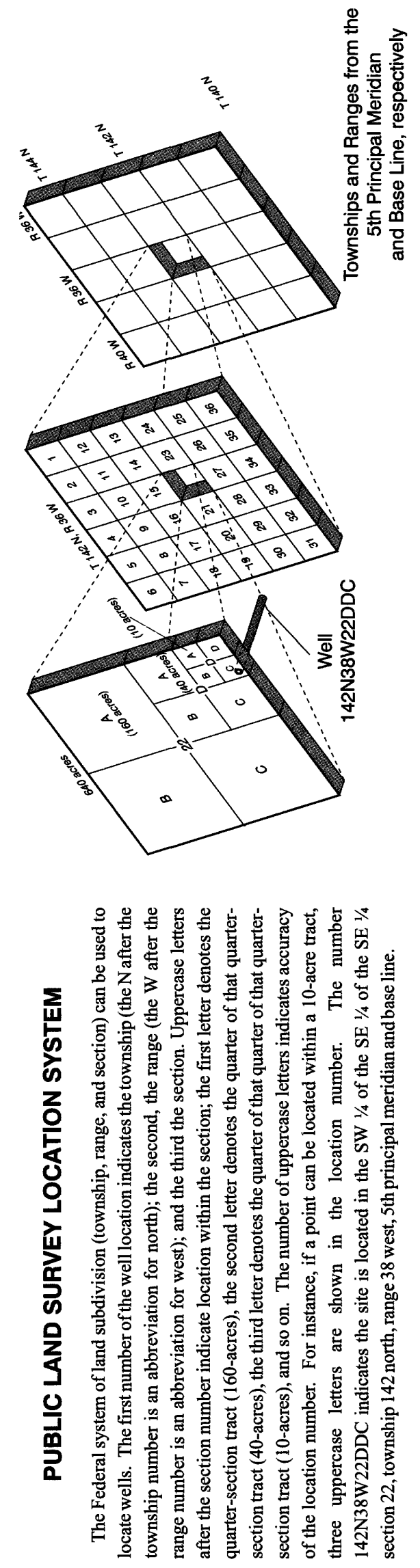


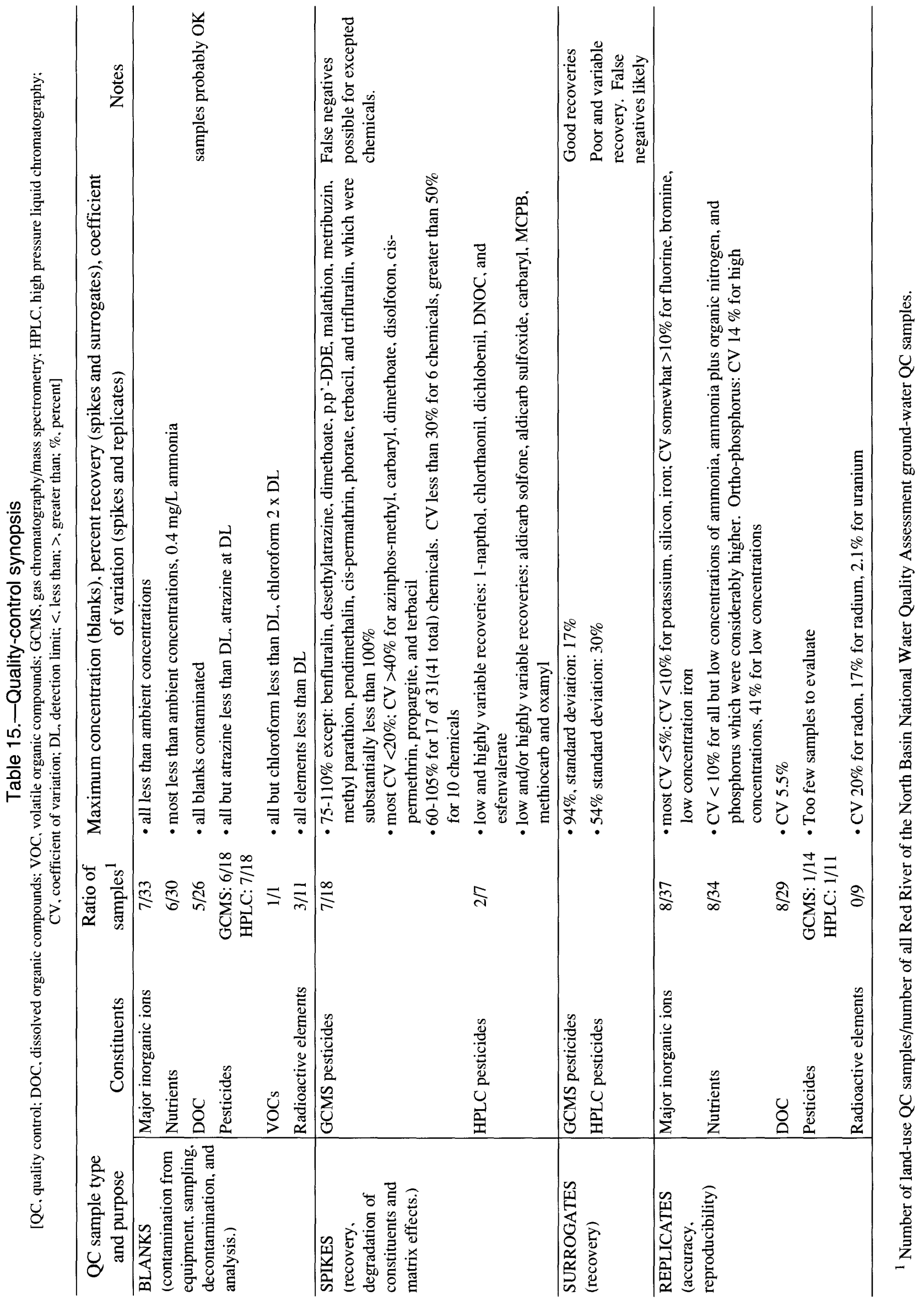

